\title{
PHOTOMICROGRAPHS OF
}

\section{BOTANICAL STUDIES}

(COPYRIGHT) 



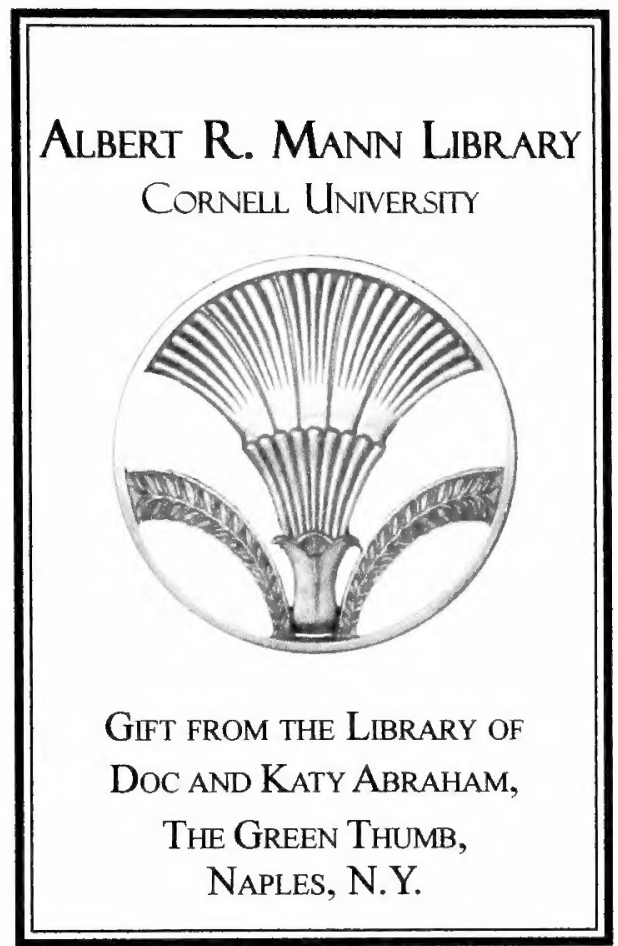




\section{Cornell University Library}

The original of this book is in the Cornell University Library.

There are no known copyright restrictions in the United States on the use of the text.

http://www.archive.org/details/cu31924089418929 


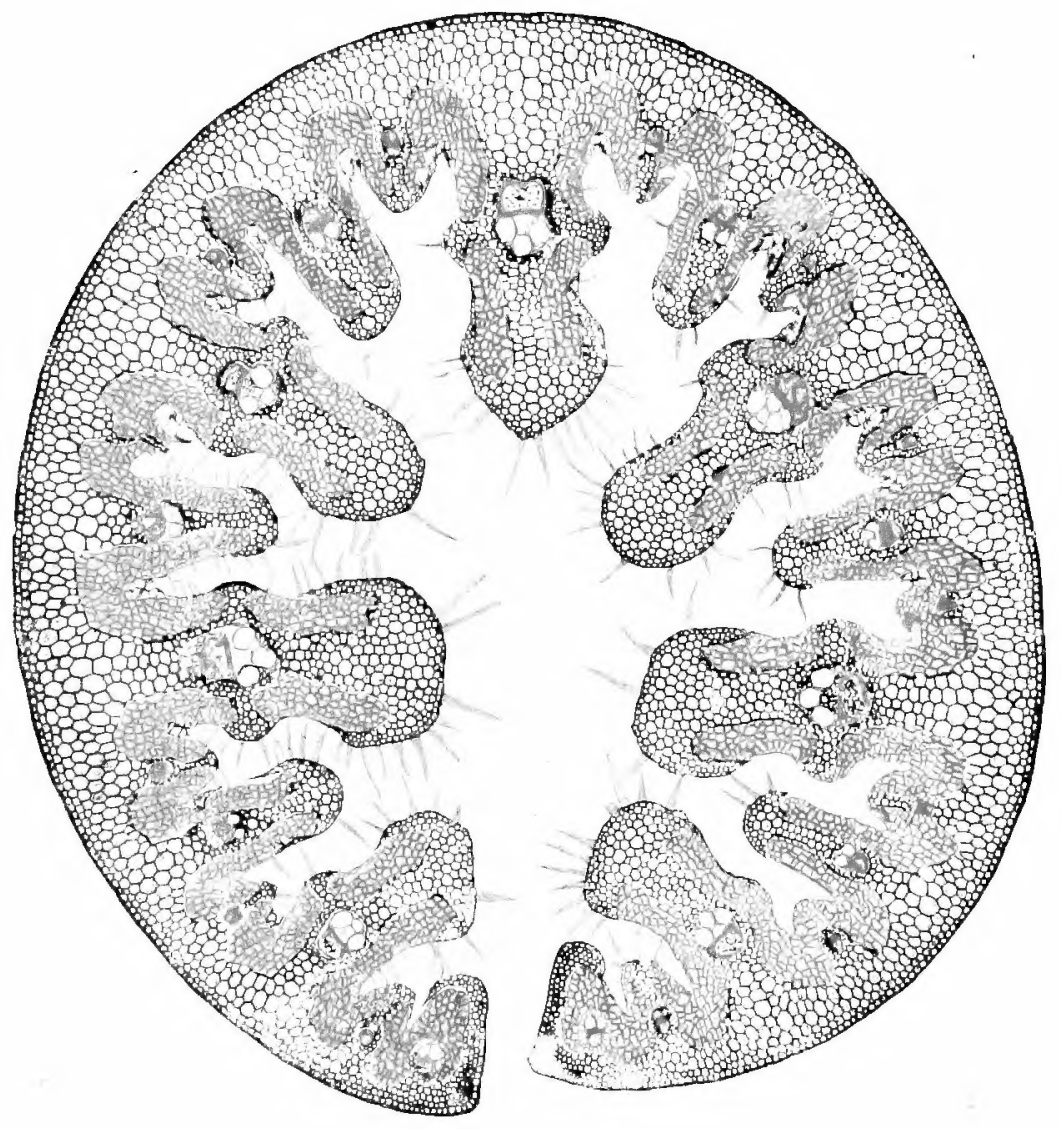

T.S. LEAF OF MARRAM GRASS.

"Ammophila Arundiacea." X 35. 


\section{Photomicrographs} - OF -

\section{Botanical Studies.}

[COPYRIGHT.]

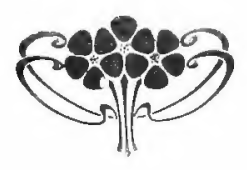

PUBLISHED BY

Flatters, Milborne \& MCKechnie, Ltd

16, $18 \& 20$, CHURCH ROAD,

LONGSIGHT, MANCHESTER.

$$
\text { PRICE } \mathbf{2}=\text { NET. }
$$





\section{ELEMENTARY SERIES}

\section{of MICROSCOPICAL SLIDES IN BOTANY.}

(Suitable for students entering for the Board of Education exanination.)

No.

s. d

1 -Allium cepa, T.S. growing point (Onion) $\ldots \ldots \ldots \ldots \ldots \ldots \ldots 06$

2- Do. I.S. do. (Karyokinesis) $\ldots \ldots .110$

3-Acorus calamus, T.S. of Root, (aquatic type) ........... 0 . 6

4 -Rootlet of Barley, root cap and root hairs ............ 6

5-Helianthus annuus, T. and L.S. Stem (Dicotyledonous type) $\ldots . .10$

6-Zea mais, T. and L.S. Stem (Monocotyledonous type) $\ldots \ldots \ldots, 10$

7-Tilia europẽa, Structure of Stem, Four Sections........... 13

8 -Cucumis sativa (Cucumber), $T$. and L. S. of Stem, Sieve tubes .... 10

9 -Auricaria imbricata, Cuticle for Stomata .............. 0 6

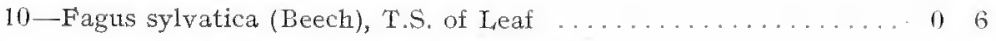

11 -Syringia vulgaris (Lilac), T'.S. of Leaf $\ldots \ldots \ldots \ldots \ldots \ldots \ldots \ldots$. 0 . 6

12-Fraxinus excelsior (Ash tree), T.S. Leaf-bud ............. 0 . 6

13 -Acer Pseudo-platanus (Sycamore), T.S. do. ............... 0 6 6

14-Do. do. L.S. of Stem, Illustrating Leaf-fall . 10

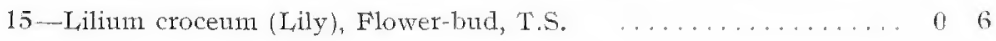

16-Taraxacum officinale, T.S. do. do. $\ldots \ldots \ldots \ldots, 0 \ldots$

17-Lychnus diurna, L.S. of Ovary (Free central placentation) $\ldots \ldots 606$

18 - Lilium croceum, T.S. of Embryo $\mathrm{Sac} \ldots \ldots \ldots \ldots \ldots \ldots \ldots \ldots$

19 -Triticum sativum (Wheat), L.S. $_{\text {. }}$ of Seed $\ldots \ldots \ldots \ldots \ldots \ldots \ldots$

20 - Solanum tuberosum, Section of tuber, Starch in situ ........ 0 6

21-Taraxacum officinale, L.S. of Root for Sphoro-crystals of Inuline $\begin{array}{ll}0 & 6\end{array}$

22-Ricinus communis, T.S. of Seed for Aleurone grains ........ 0 6

23-Scorzonera hispanica, L.S. of Root for Laticiferous vessels ..... 0 ( 6

24-Rheum palmatum Turkey Rhubarb, T.S. of Root for cluster crystals $0 \quad 6$

25 - Phajus grandifolius (Orchis) Tuber, for Leucoplastids . . . . . . 060

26-Ficus elastica (India-rubber plant), T.S. of Leaf for Cystoliths $\ldots 006$

The series of 26 slides in rack-box, $15 /-$. 
1 - Pleurococcus

2-Torula (reast)

3 Nostoc, "sp."

4-Spirogyra (inl conjugation)..

5 -Closterium, Sp

6-Vaucheria (fertilization stage)

7 - Volvox globator ...........

8-Fucus vesiculosus, V.S. of conceptacle, for Antheridia and oogonia

9-Scab I Iiseases of Potato (Resting Spores)

10 - Puccinia granninis, Tredo teleutoand tcidiospores.

11 - Igaricus campestris, Y.S. of

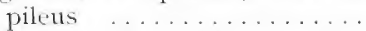

12-Parmelia, Sp. Y.S. of Apo-

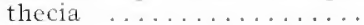

13-Polytrichun, sp. T.S. of Stem

14-I,ycopodium claratum, Sporangia ...............

15-Fetn, Sp. Antheridia and Archegonia .................

16- Leaf and Sori, T.S. Pteris aquilina

17-Rhizome, T. \& L. S., Pteris aquilina

18-Fquisetum telanteia, T.S. Fertile spike

19-Equisetum telmateia, T. \& I.S. of Tegetative bud ........

20-Do. do. Meristem tissue..

21 -Pinus sylvestris, T.S. Stem, for developing tissue (three stages)

22-Pinus Sylvestris, T.S. of Root

23 . Do. do. do. of Leaf

$24-100$ do to tomber

25-Tio. do. R.L.s do.

$26-50$ do. T.L.S. do.

27-1)o. do. L.S. Staminate-strobilus .........

28-Do. do. T.S. Polycotyledomous ovule

29-Hippuris vulgaris, I.S. growing point ..............

30-Taba vulgaris (Bean), T.S. Stem, Hypocotyl, and Root

31 -Helianthus Annuus (Sunflower) T. \& I.S. of Stem. Dicotyledonous type.....

32-Tilia enropica (Lime tree), T. \& L. S. of stem (fout sections)

33 - Sambucus nigra, T.s. Stem (lenticels) $\quad \ldots \ldots \ldots \ldots$

34-T)racena, Sp., T.S. Stem (connecting type).

$\begin{array}{cc}\text { s. } & \text { d. } \\ 1 & 0 \\ 1 & 0 \\ 0 & 6 \\ 1 & 0 \\ 0 & 6 \\ 1 & 0 \\ 1 & 0\end{array}$

35-Zea mais, T. \& I. S. of Stem, Monocotyledonous type .. 10

36-Cucumis sativa, T. \& L.S. of Stem for sieve tubes...... 10

37-Leaf buds T.S. of Fagus sylvatica (Beech) ....... 06

38-Leaf buds of Quercus, Sp.,

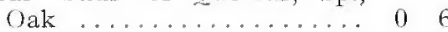

39-Leaf buds of Acer Pseudoplatanus T.S. Sycamore...

40-Acer Pseudo-platanus L.S. Stem to illustrate Defoliation .............. 10

41-Ficus elastica, T.S. of Leaf (Cystoliths) ............

42 Fagus sylvatica $\mathrm{T}$ s of Ioaf 0

43-Auricaria imbricata (Cuticle), Stomata

44-Sedum Sp. Cuticle for Stomata 45-Papaver rhas, T.S. Flower bud (Poppy) ...........

46-Cheiranthus cheiri T.S. (Wallflower) .............. 06

47-Lilium croceum, T.S. Filower bud ............... 0 6

48-Taraxacum officinale T.S. Flower bud ............ 06

49 - Taraxacum officinale L.S. Flower bud .............

50-Capsella Bursa-pastoris (Shepherd's-purse), Entire Cap-

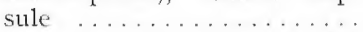

51-Do. do. Sections of developing Embryos ....... 10

52-Lilinm Croceum do. do. do. 10

53 -Lychnis, Sp. L.S. Ovary (Free central placentation)......

54-Cremocarp, T.S. Typical U'm bellifere ............. o 6

55 -Ricinus communis, T.S. Seed, aleutone grains ..........

56 -Phagus grandifolius, ' T. S. Tuber (Leucoplastids) ...

57-Rheum palmatum, T.S. Root, Cluster-crystals ........

58-Taraxacum officinale, L.S. Root for Spharo-crystals of Inuline

59-Pelionia Sp. T.S. Stem, for Starch ............... 06

60-Potato, Section, for Starch . 006

The complete series of 60 slides in rack box .............. 50

Do. in pine cabinet........ \& \& 0

(This series may be varicd to meet educational requivements). 
of

MICROSCOPICAL SLIDES IN BOTANY.

1 -Protococcus

2 - Scenedesmus ................ 10

3 -Volvox globator ........... 10

4-Vaucheria sessilis, fertilization stage $\ldots \ldots \ldots \ldots \ldots \ldots, 10$

5 - closterinm ...............

6 -Diatoma vulgaris ......... 006

7 -Spirogyra, Sp. In conjugation and Zygospore, stages.... 10

8 -Ulothrix .............. 0

9-Fucus vesiculosus, V.S. of Conceptacle, for Antheridia and Oogonia ............ 10

10 - Torula (Yeast) ............ 10

11-Hucor mucedo, asexual reproduction, from pure culture..

12-Pythium, Sporangia ........ 10

13-Penicillium, pure culture .... 10

14-Agaricus campestris, V.S. pileus ............. 06

15-Peziza convexula, V.S. of Apothecia ............ 06

16-Parmelia, Sp. V.S. of do. 06

17-Polytrichum (Moss) T.S. of

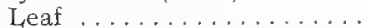

18-Lycopodium clavatum, T.S. of Stem .....................

19-Capsule, of Moss, Funaria V.S.

20-Antheridia, and Archegonia, of Funaria ............ 16

21-Sporogonium of Pellia, L.S. 006

22-Antheridia, Marchantia polymorpha
23-Archegonia, Marchantia polymorpha ........... ()

24--Sporogonia, Marchantia polymorpha ........... (1)

25-Antheridia and Archegonia of Fern, Prothallus entire .... 1 (1

26-Leaf and Sori, V.S. Scolopendrium vulgaris

$0 \quad 6$

27-Pteris aquilina, ' $\Gamma$. and L. S. of Rhizome ............ 1

28-Pteris aquilina, V.S. Sori .... o 6

29-Selaginella Wildenovii, T.S. Stem ............. () 6

30-Do. do. Fertile Spike... 1 (1)

31-Pinus Sylvestris, T.S. of Root () i

32-Do. do. T'.S. of Stem for developing tissue, three stages .............. 1

33-Pinus sylvestris, T.S. of Leaf o t

34 - Do. T.S. Timber ... 0 ()

35 - Do. R.L.S. do. (1) 6

36 - Do. T.L.S. do. 0 . 6

37- Do. L.S. Staminate strobilus () (3

38- Do. T.S. Polycotyledonous Ovule $0 \quad 6$

39- Do. L.S. Embryo Sac.. 1 (1

The complete series of 39 slides in rack. box $\ldots \ldots \ldots \ldots \ldots \ldots 1 \quad 5 \quad 0$

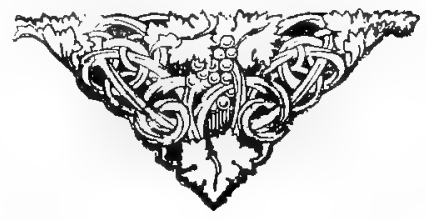




\section{PREFACE.}

In placing this hook of PHOTOMICROGRAPHS in the hands of Teachers and Students, we feel that we are supplying a long-felt want. No such work has previously been published.

The work covers practically the whole range of study requisite for the Botanical Student, and should be in the hands of everyone who is desirous of studying from the actual preparations, in place of, as in many cases, crude ideal sketches.

In the production of Microscopical preparations and Photomicrographic reproductions therefrom, we now occupy a unique position; as our preparations are the standard by which all others are judged.

ABRAHAM FLATTERS, F.R.M.S.

Teacher in Microscopical Research to the Municipal School of Technology, Manchester. Specialist in Micro-Technology to the Manchester Chamber of Commerce.

\section{Published by}

platters, MLLBORNE and MCKECHNIE, Ltd., 16, 18 and 20, Church Road, Longsight, Manchester. 


\title{
INDEX.
}

\author{
Abbreviations to Illustrations :- \\ T.S.-Transverse Section. \\ L.S.-Longitudinal Section. \\ R.L.S.—Radial Longitudinal Section. \\ T.L.S.--Tangential Longitudinal section. \\ V.S.--Vertical Section.
}

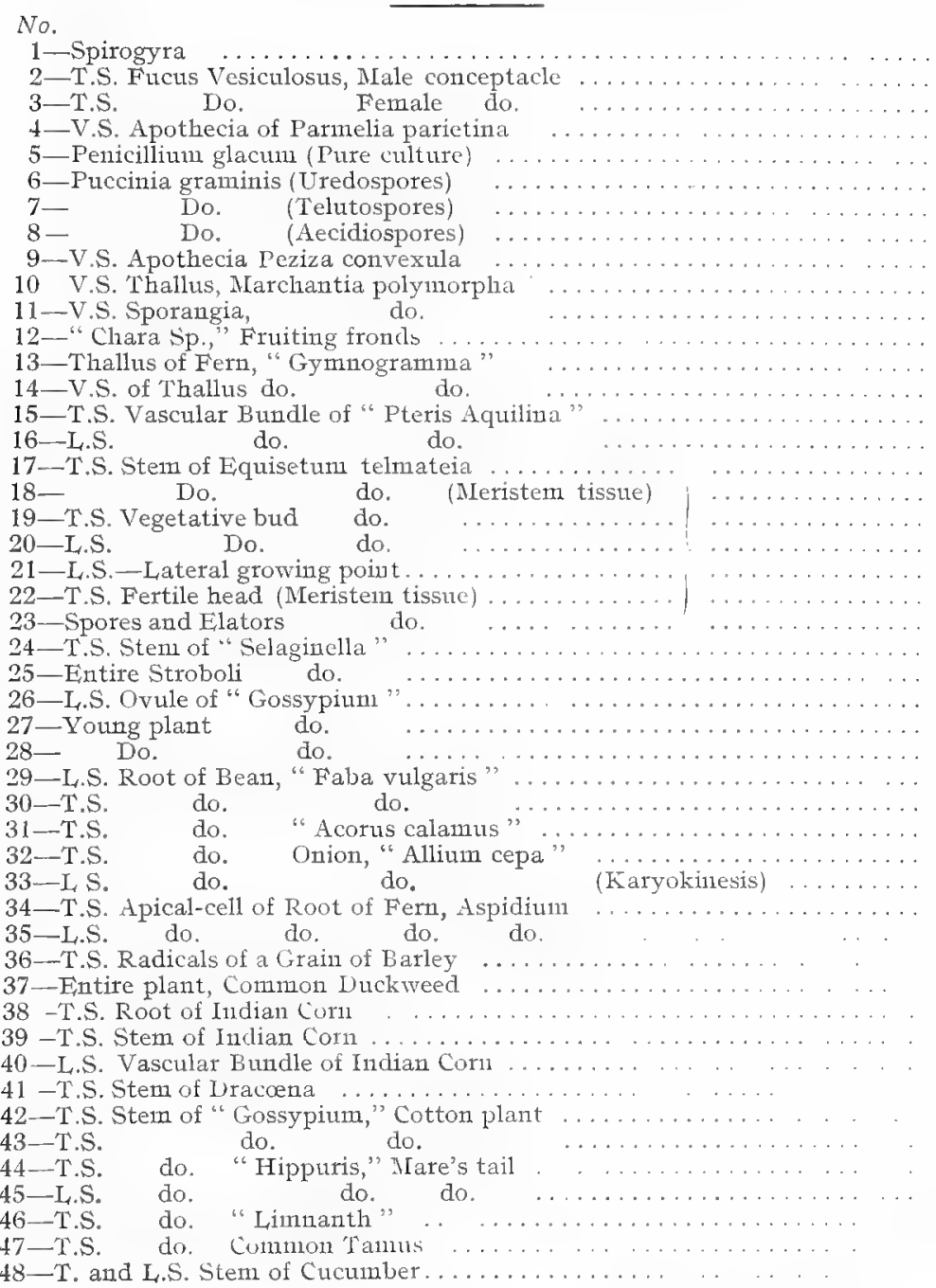




\section{INDEX-continued.}

49 -T.S. Sten of sunflower

50) $-\mathrm{I}_{4} \mathrm{~s}$. de.

51-1.S. do. Lime-tree

52-T.L.S. do. do. (Bast area)

53 -T.L.S. do. do. (Wood do.)

54-1.s. Ront of I'ine-tree

55 -L.S. Stem

$56-1 . S$. do.

o (growing point)

57 T.S. do.

do. (dereloping tissuc)

58 -L.S. do

do. (advanced stage)

$59-T$ - do

do. do.

60-T.S. Iseaf

(1) (resin passage)

61-L.s. Male Cone

(is.

62-l'ollen from arale conc, Ininc-tres

63-L.s. Ovule

6it T.S. do. Hature

65-T.S. Timber

$66-$ R.L.S. do.

iif-1 L.S. do.

68 I eaf cuticle of turicaria

69 - Tascular ramifications of Leat of Intentilia"

70 - T.S. Leaf of "Metrosicleros"

71 - Sting of Nettle...........

72 -T.S. Fliylode of Acacia .....

73 -'T.S. (ircen stene of switch-1)room

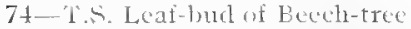

$75-1.5$. do. Ash-tree

It 1 is do. Sycamore

77 I. S. Stem and Iteaf-buds of sycamore (I)efoliation).

7is 1. S. Fluwer bud Cotton plant

74) - It $\rightarrow$. Catkin of solis

Si- T.S. Flower buil of I andelion

SI T.S. INo. L'oppy ..

(2.) -T.S. Do. Wallfower

ה3-T.S. Do. Iris

St-I.S. Do. Lilimm croceum

85 -l's. Anther ro.

$86-T . S$. Orary 87 - Fower entire of the wheat

88 - Stigma and l'ollen of the Wheat

89- Lo. do. Enlarged

90-1.S. Uvary of do. du.

y1 -L.s. Seed of do. do

92-I.s. Plumule of do. (14)

93 -L.S. Radical of do. (lo

94-T's Seed of (1). do Linlarecel

y5 'T. Cremocarp of "sikyminium"

96 - Capsule entire ol Sluepherd's-purse

97-Starcle of I'otato

98-1.5. Sten of 'lradiowatia fur starcin

yy - T.s seed of Castor-(bl plant......

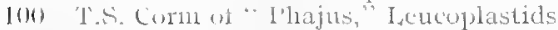

101 -L.s. Root of Dindelinit, spluero crystals

I0!2 -L.s. Stene of Limplorbia

$103-I_{+} .5$. Root of Sicorzonera. 
TO make a complete study of a solid mass of tissue, Sections must be cut at different planes to each other, viz:-Transverse, Radiallongitudinally, and Tangential-longitudinally. Each Section when placed under the Microscope will present to the observer a surface cut at right angles to each other.

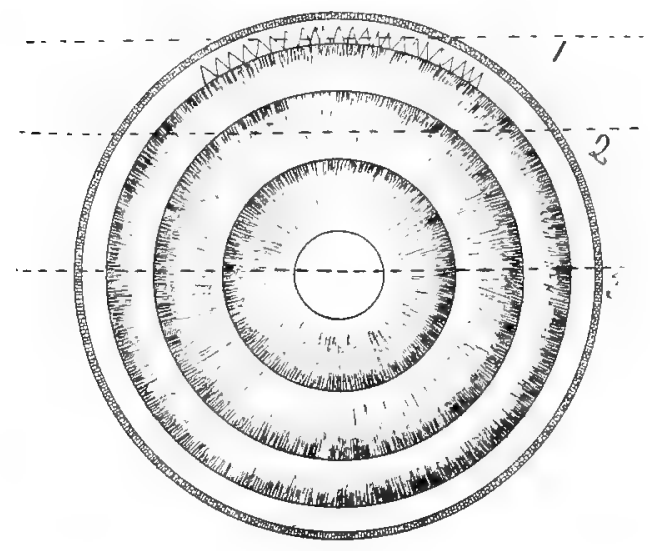

\section{DIAGRAM OF A DICOTYLEDONOUS STEM.}

1-Tangential area, passing through the Bast Fibres, (see Nos. 51 to 53).

2 -Tangential area, passing through the Xylem (wood).

3-Radial line, passing through the Pith. 

1.-Spirogyra (In conjugation).

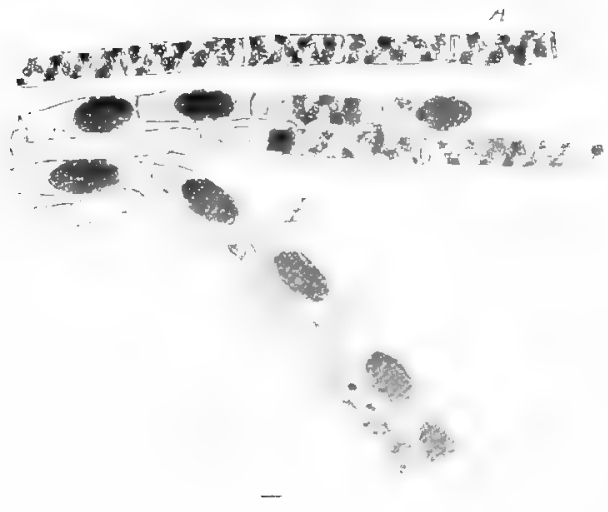

$A$, Filament in normal vegetative condition.

$B$, Filaments in conjugation.

2. -T.S. Male Conceptacle, "Fucus vesioulosus."

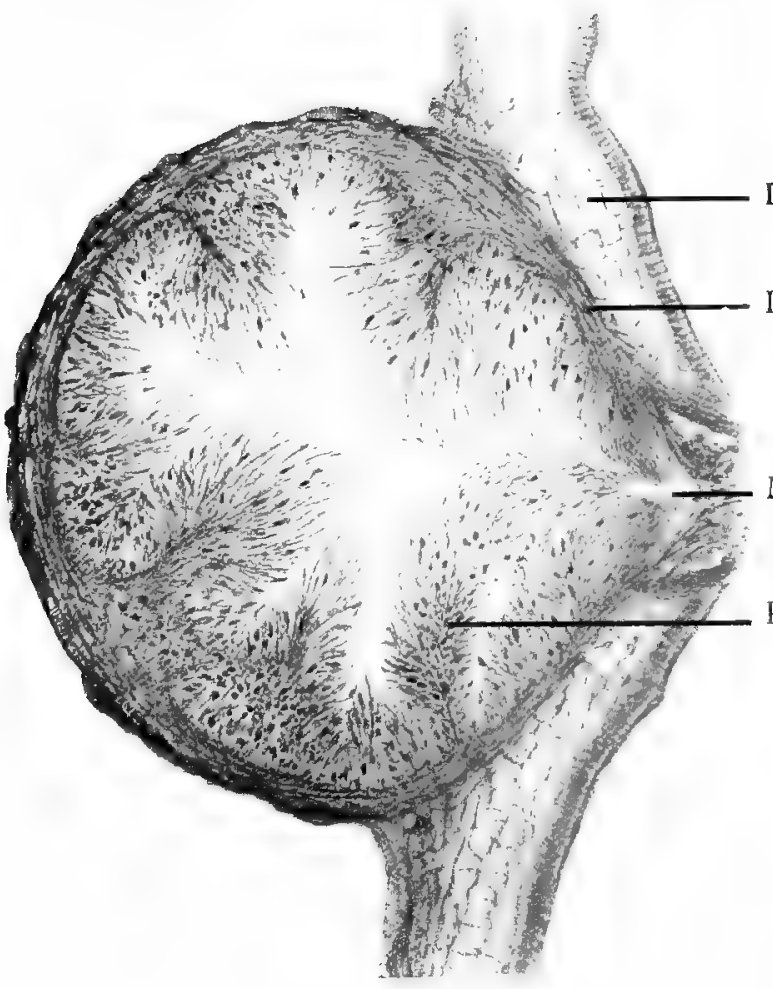

Limiting tissue of thallus.

Lining of conceptacle.

Mouth of conceptacle.

Protective hairs among which are distributed the antheridia. 
3.-T.S. Female conceptacle, fucus vesiculosus.

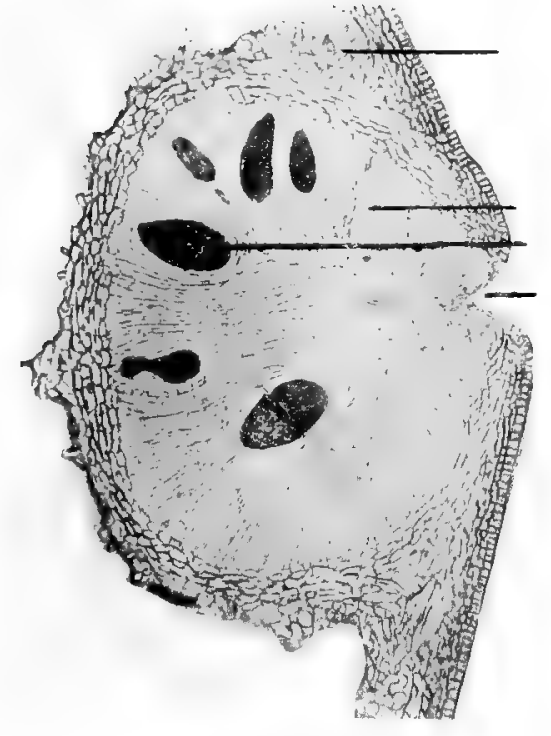

Limiting tissue of thallus.

Protective hairs.

Oogonia in various stages of development.

Mouth of conceptacle.

4.-V.S. Apothecia, Parmelia parietina.

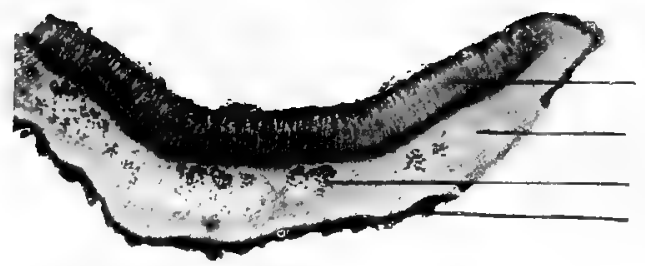

Apothecia containing spores.

Mycelium.

Unicellular algre.

Rhizoides or root-hairs. 
5.-Penicillium glaucum.

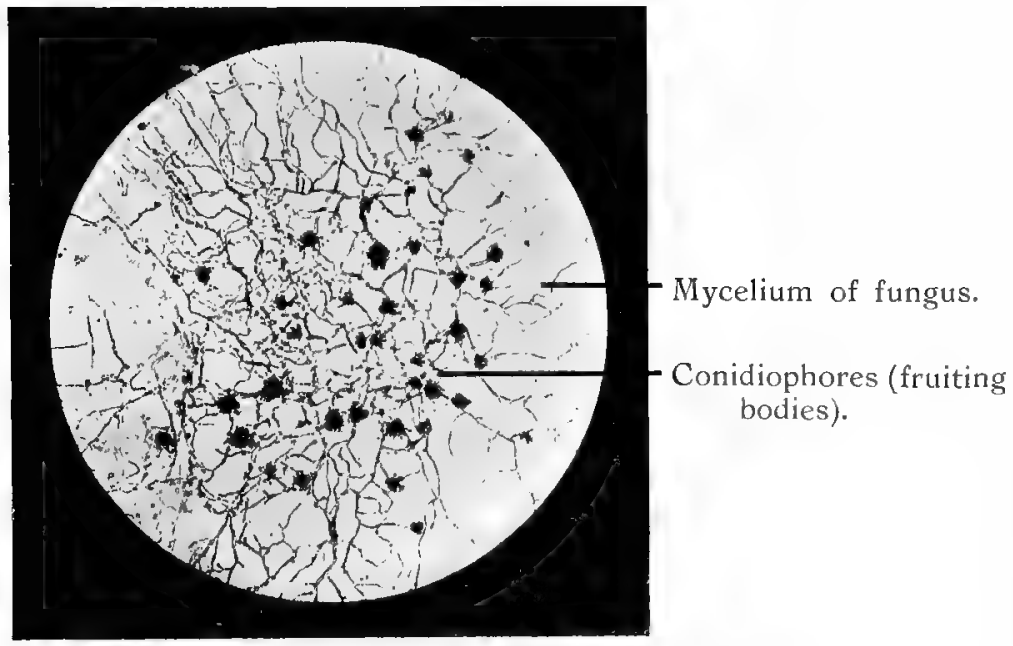

6. - T.S. Leaf of Thistle "Carduus," attacked by uredospores of puccinia graminis.

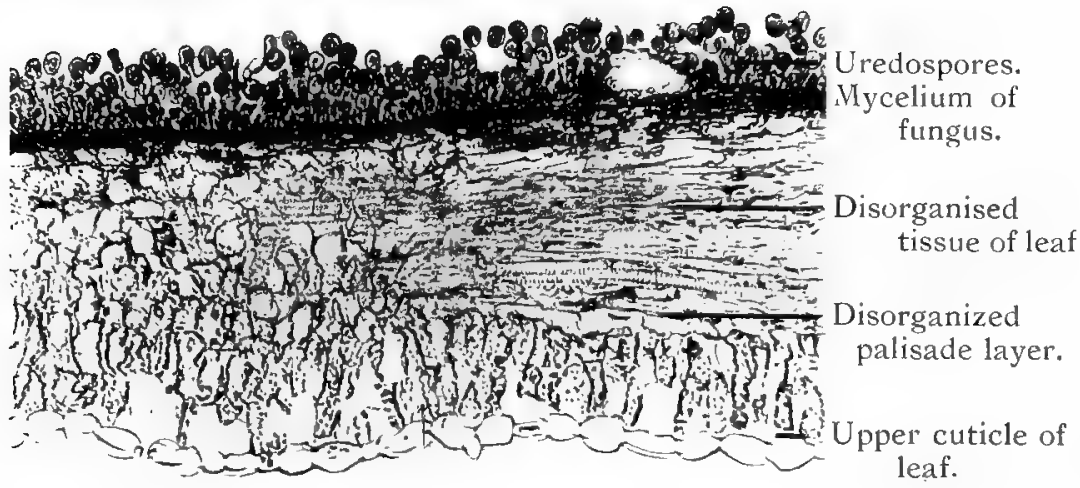


7.--T.S. Stem of Wheat, "Triticum." Attacked by teleutospores of puccinia graminis.

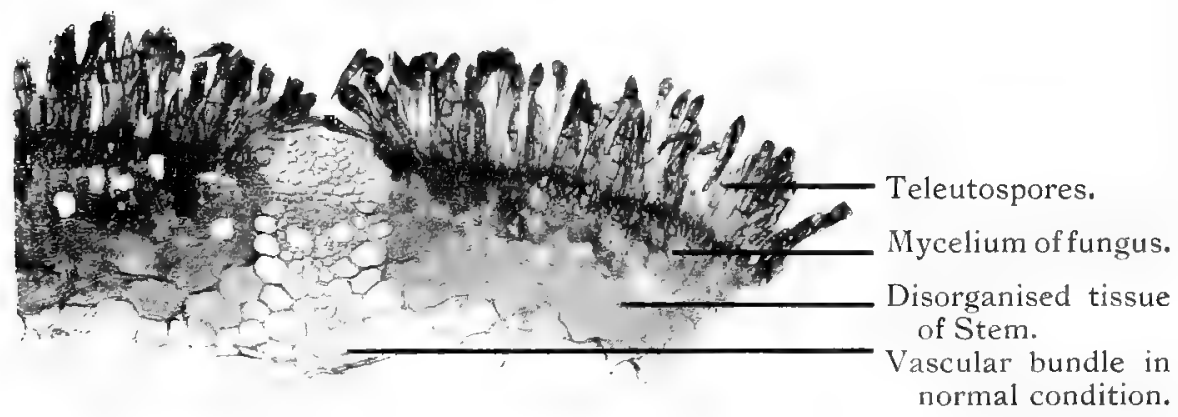

8. T.S. Leaf of Berbery. Attacked by aecidiaspores of puccinia graminis.

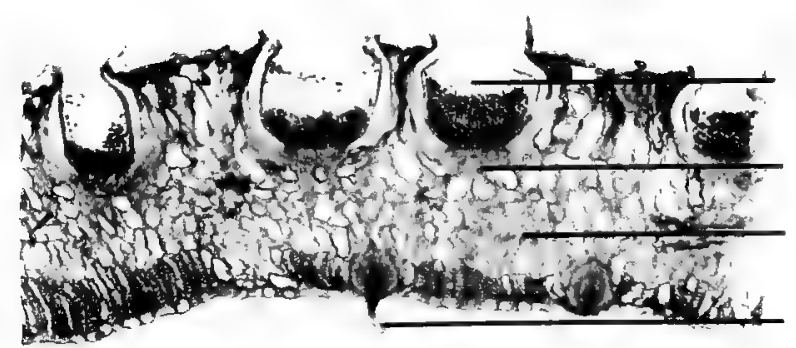

Fully-developed æcidium.

Mycelium of fungus.

Disorganised tissue of leaf.

Spermogone of unknown function. 


\section{9.-V.S. Apothecia, Peziza convexula.}

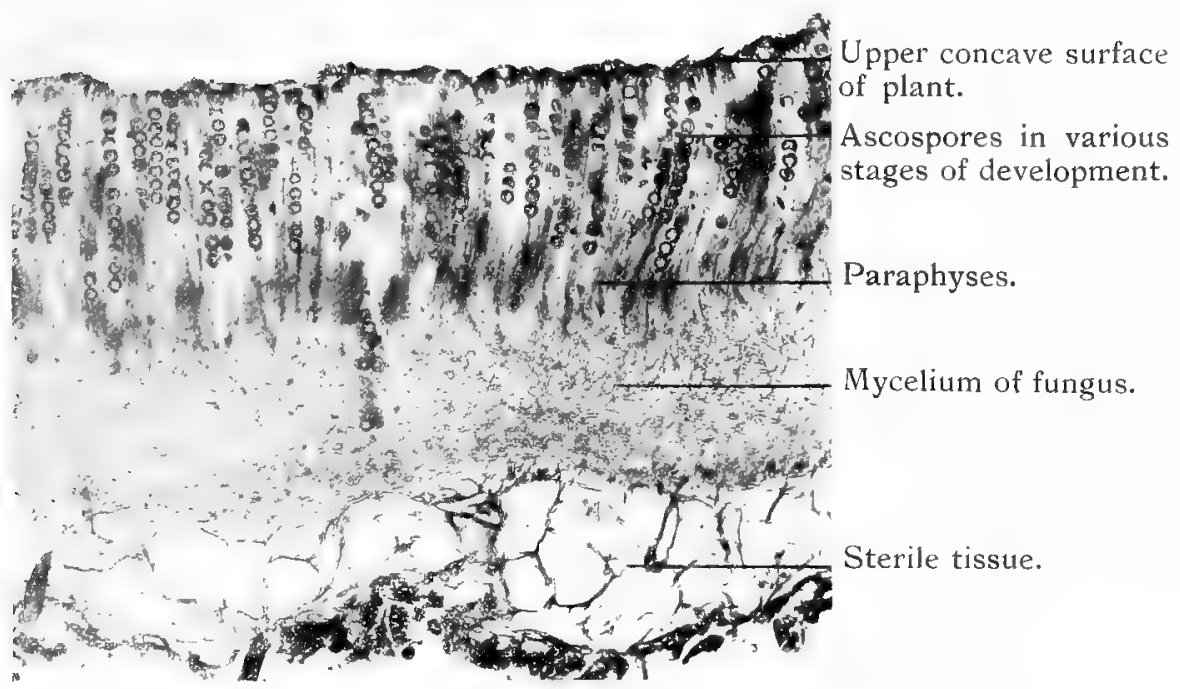

10.-X.S. Thallus of "Marchantia polymorpha."

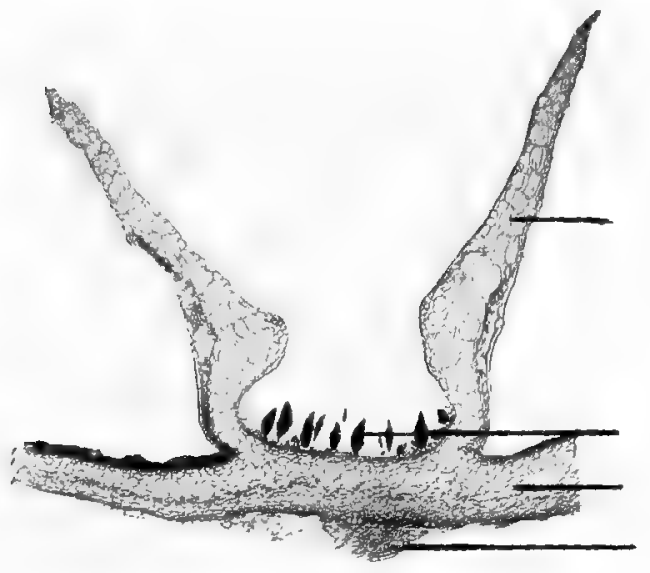

Wall of gemmæ cup.

Gemmæ in various stages of development. Thallus.

Root-hairs (rhizoids.) 
11.-Y.S. Sporangia of Marchantia polymorpha.

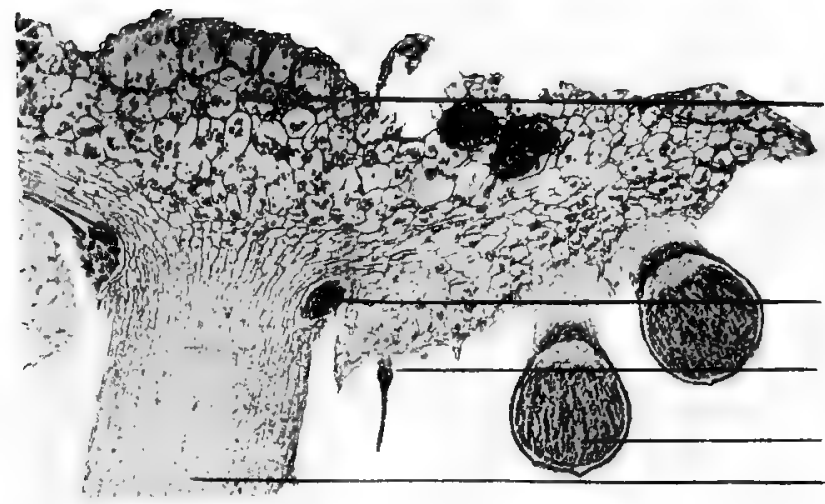

Upper portion of stellate disc of thallus.

Fibrous bundle.

Archegonia

(Unfertilised) Sporogonium, with spores and elaters. Stall of stellate disc.

12.-Fruiting Fronds, of "Chara sp."

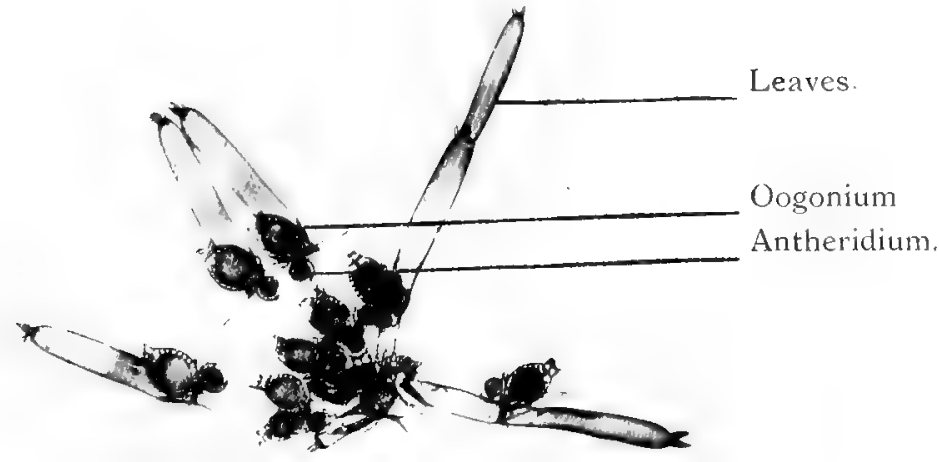


13. - Underside of entire Thallus of Fern, "Gymnogramma Sp."

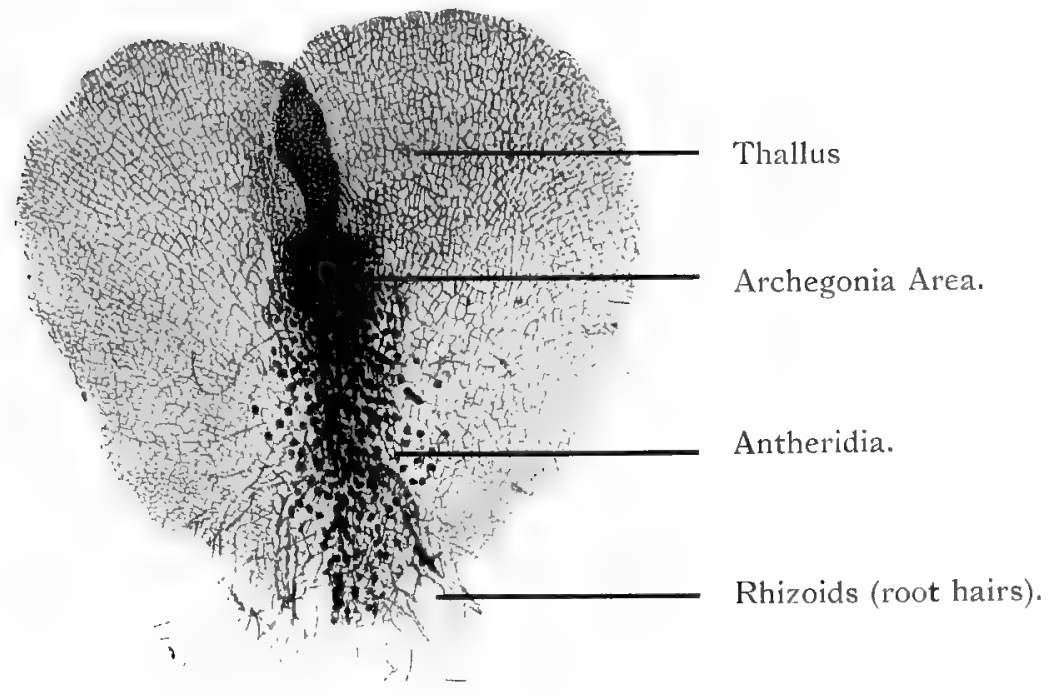

14.-Y.S. Thallus of Fern, "Gymnogramma Sp." (Passing through Archegonia area).

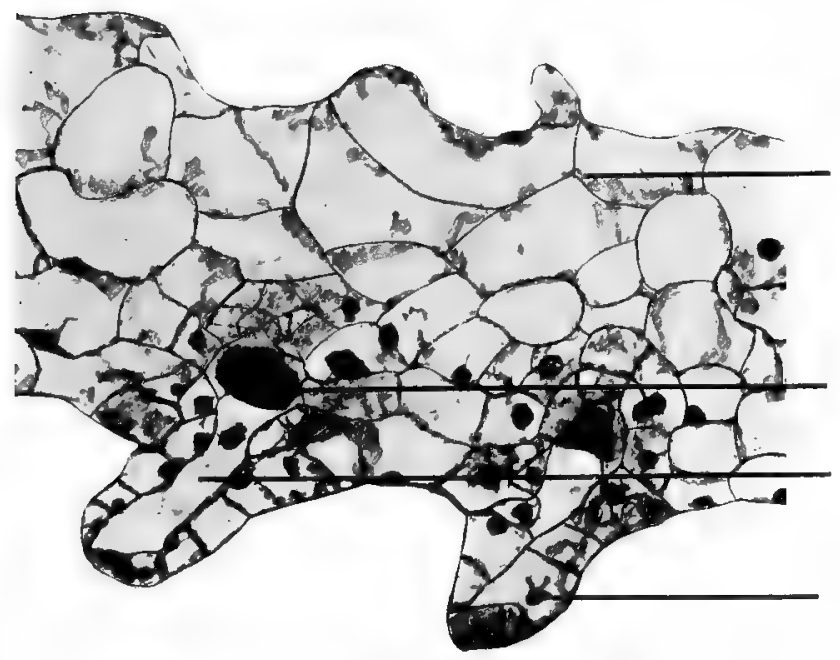

Upper surface of Thallus.

Ovum.

Canal of neck open.

Do., out of Median plane. 
15-T.S.-Through Yascular bundle of Rachis, of Pteris aquilina.

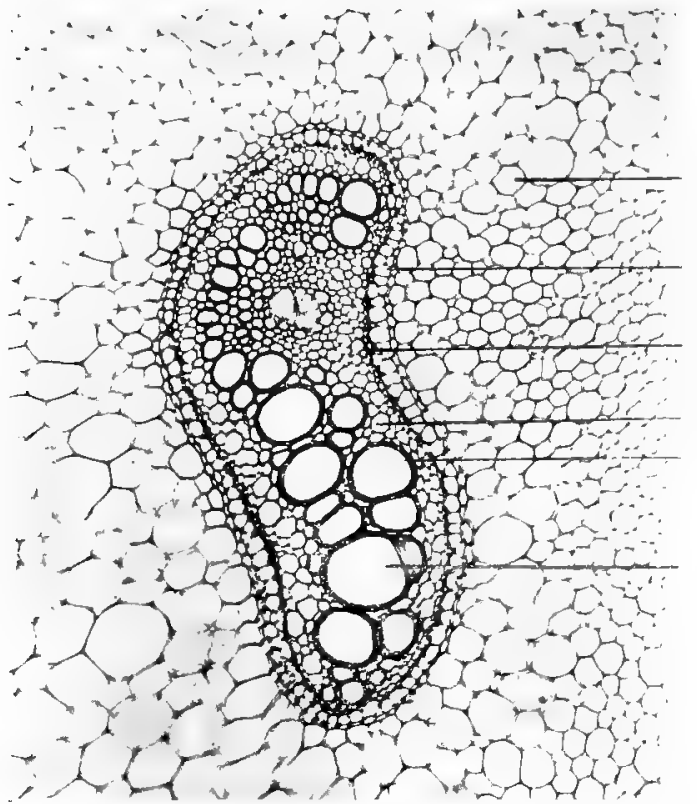

Primary ground tissue.

Endodermis.

Bast sheath.

Bast elements.

Spiral vessels.

Scalariform vessels

16 -L.S.--Through Vascular bundle of "Rhizome," of Pteris aquilina.

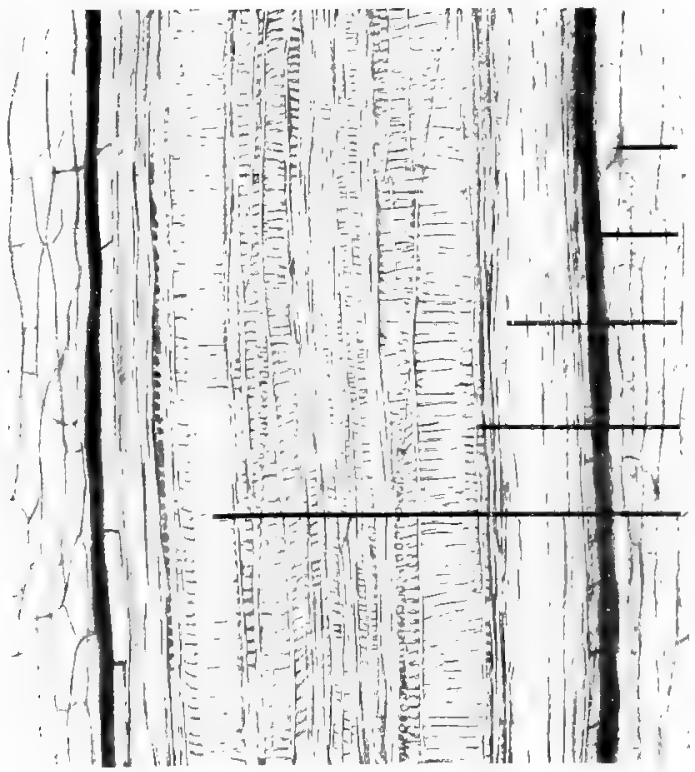

Primary ground tissue

Sclerenchyma sheath

Bast elements.

Spiral vessels.

Scalariform ressels. 
17.-T.S. Stem of "Equisetum telmateia."

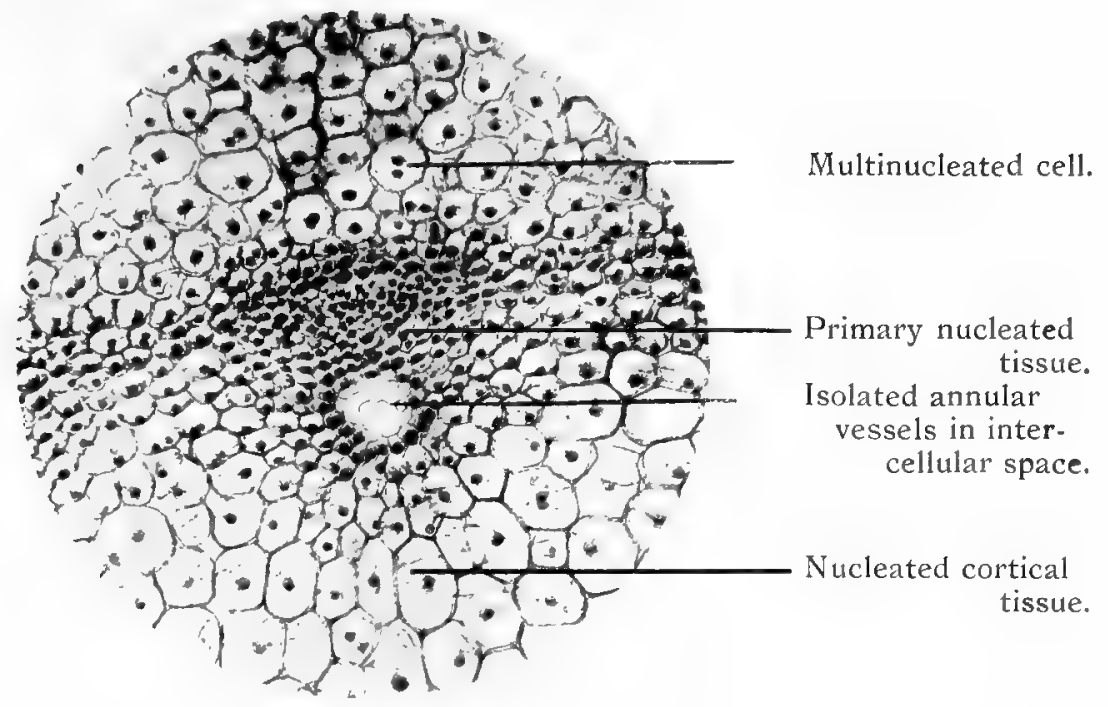

18. -T.S. Stem of "Equisetum telmateia."

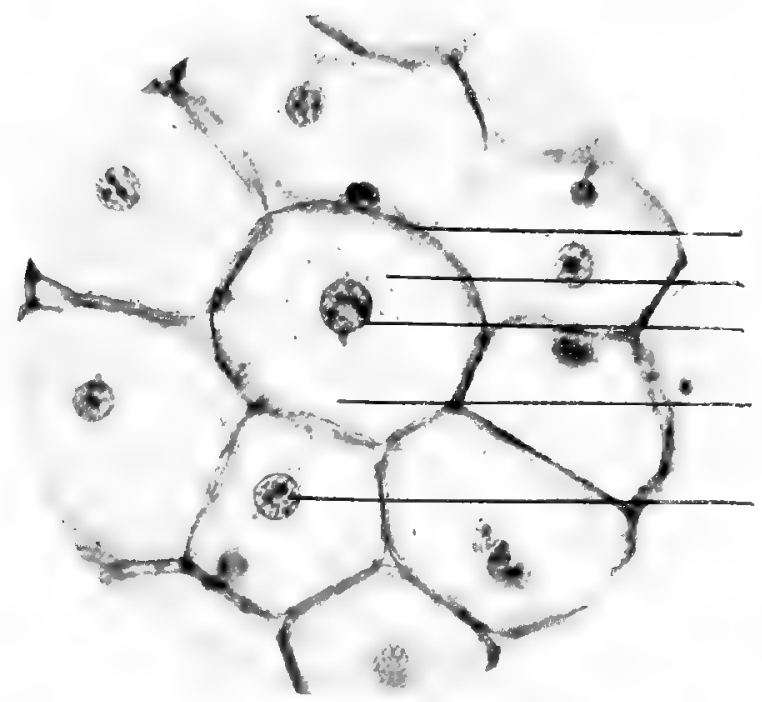

Cell-wall.

Protoplasm surrounding nucleus.

Nucleus.

Strands of protoplasm connecting nucleus with cell-wall.

Nucleus with nucleoli. 
19 -T.S. Yegetative bud of "Equisetum telmateia."

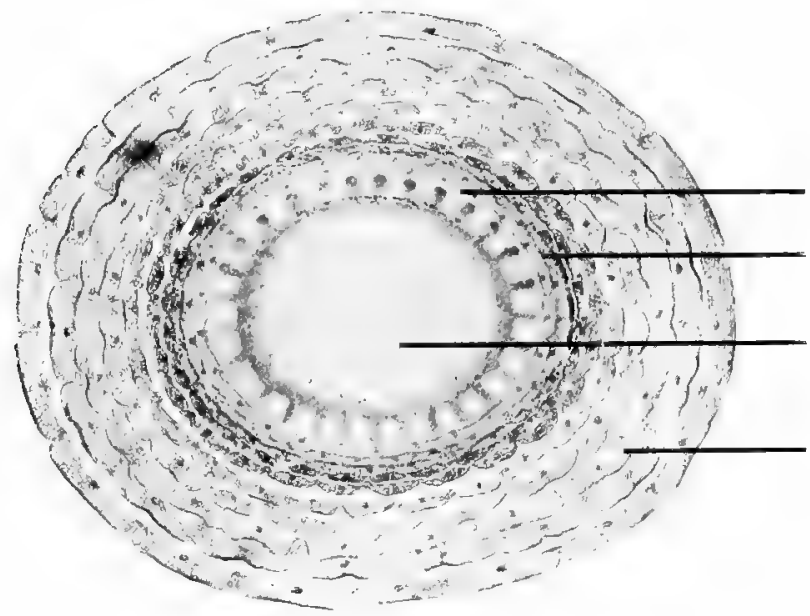

Zone of vascular bundles.

Leaf-sheath with developing leaves. Central axis of stem

2(). L.S. Yegetative bud of "Equisetum telmateia."

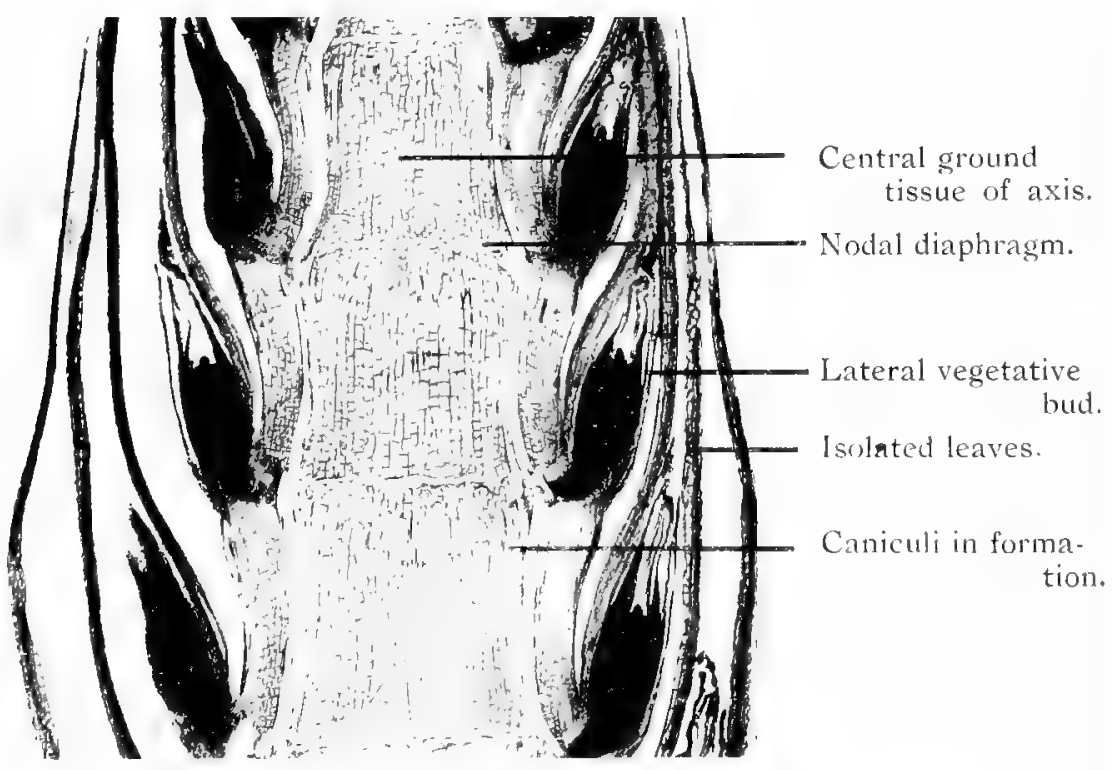


21.- L.S. Lateral growing point of "Equisetum telmateia."

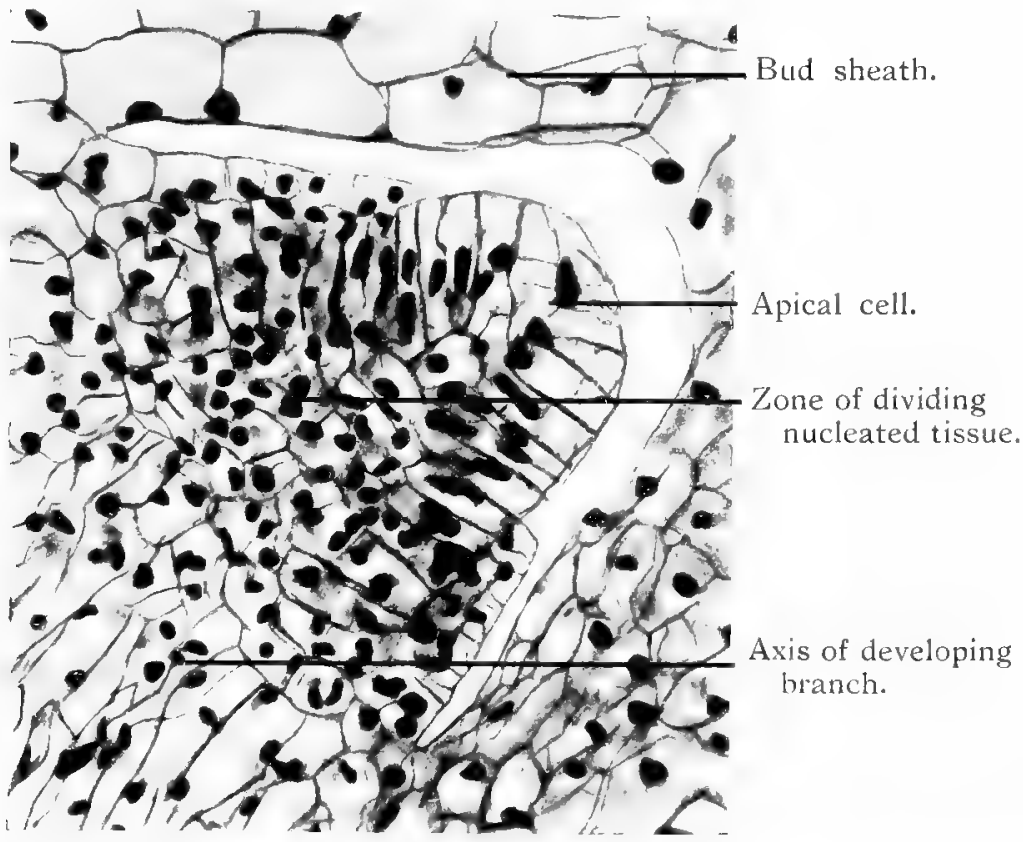

22.-T.S. Fertile head of "Equisetum telmateia.

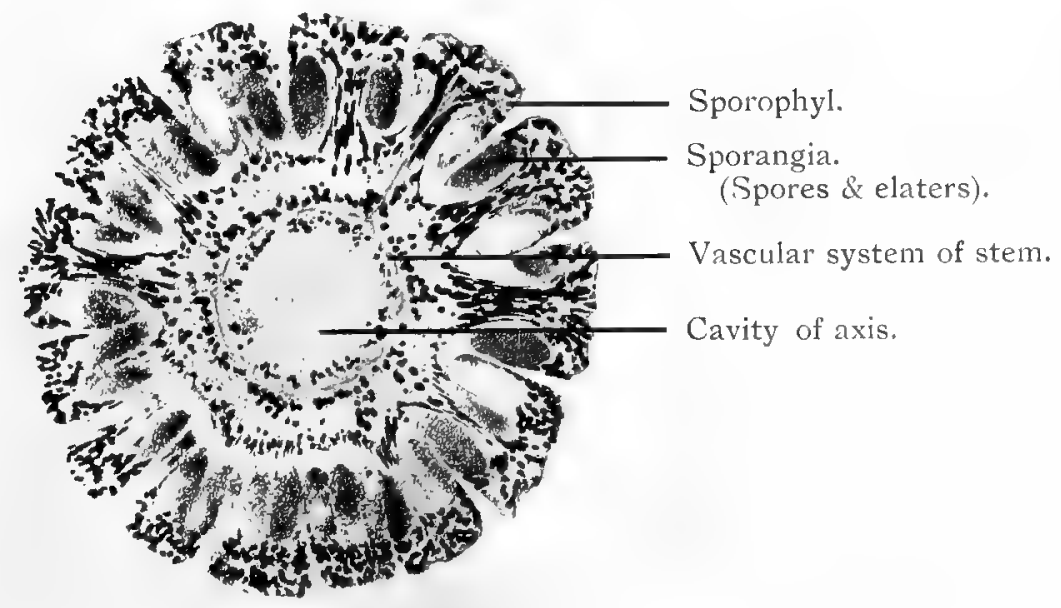


23. -Spores and Elators, from Fertile head of "Equisetum telmateia."

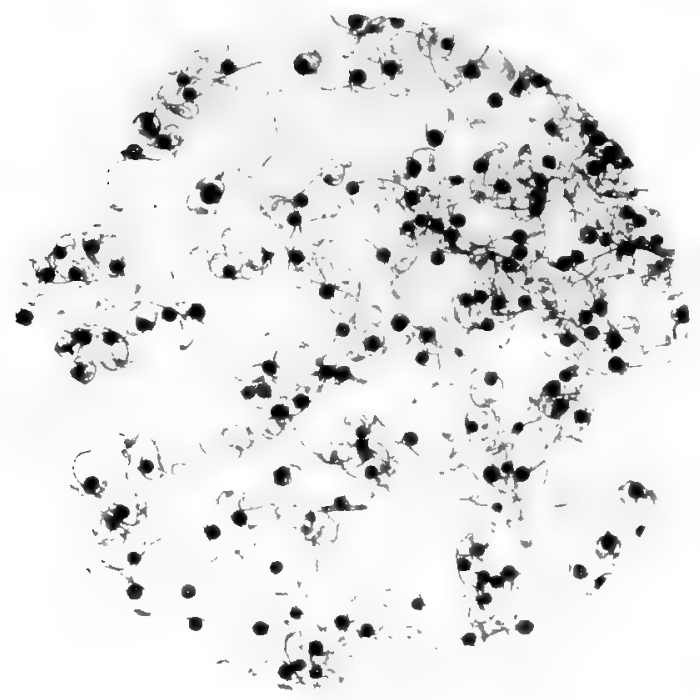

24.-T.S. Stem of "Selaginella Wildenovii."

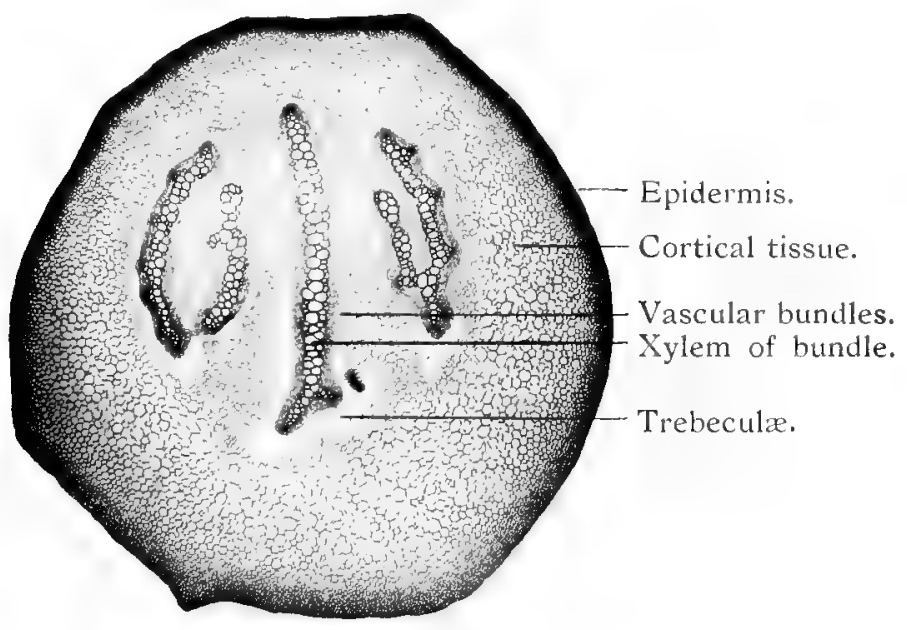


25--Entire Strobolie of "Selaginella Martensi."

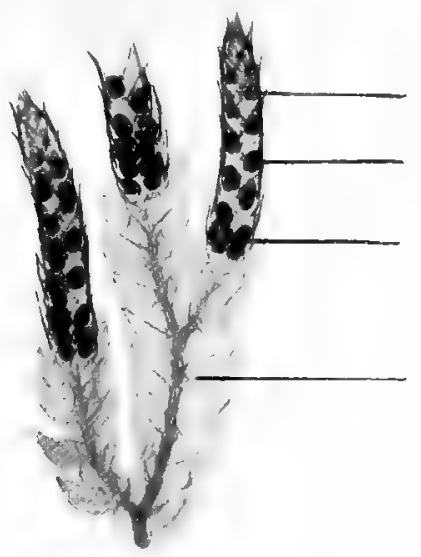

Microsporangia (various stages of development.)

Microspores fully formed.

Macrosporangia.

Fruiting branch with leaves.

26.-L.S. Embryo of "Gossypium Sp." (Cotton plant).

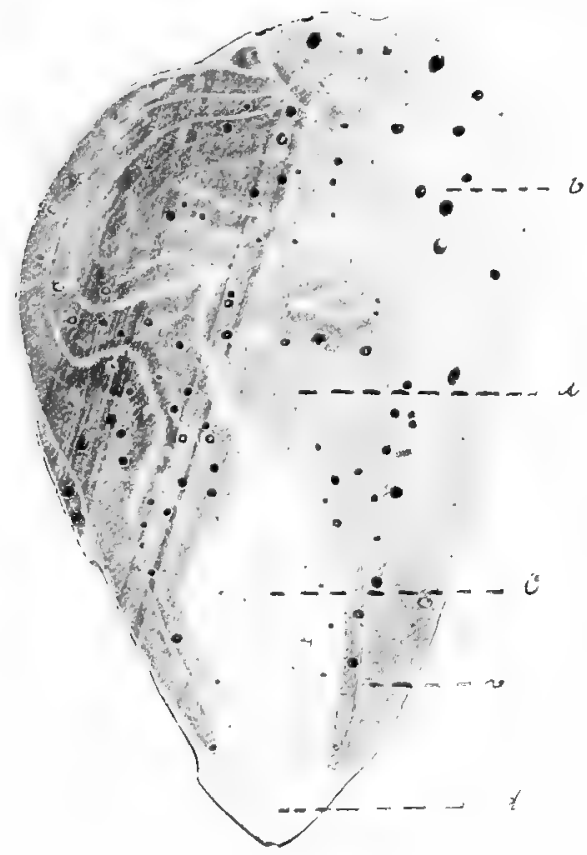

Cotyledons (First leaves) folded over the stem.

Primary axis, or stem.

The hypocotyl

Edges of Cotyledons (leaves).

Root.

Compare with 27 \& 28 . 
27.-Cotton plant "Gossypium," after eight days' germination.

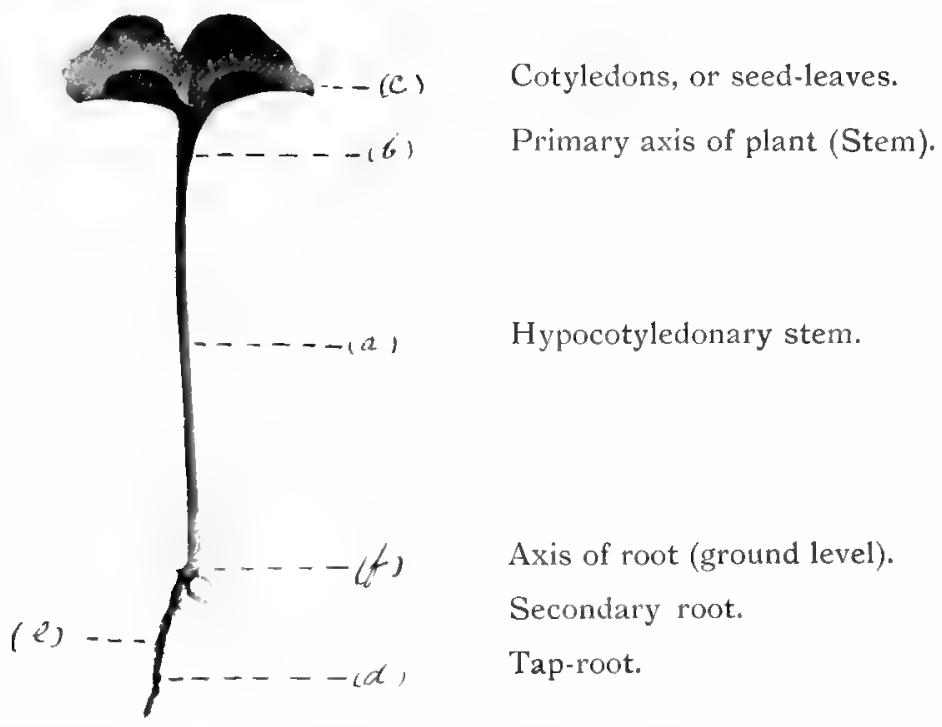

28. Cotton plant "Gossypium," after three weeks' germination.

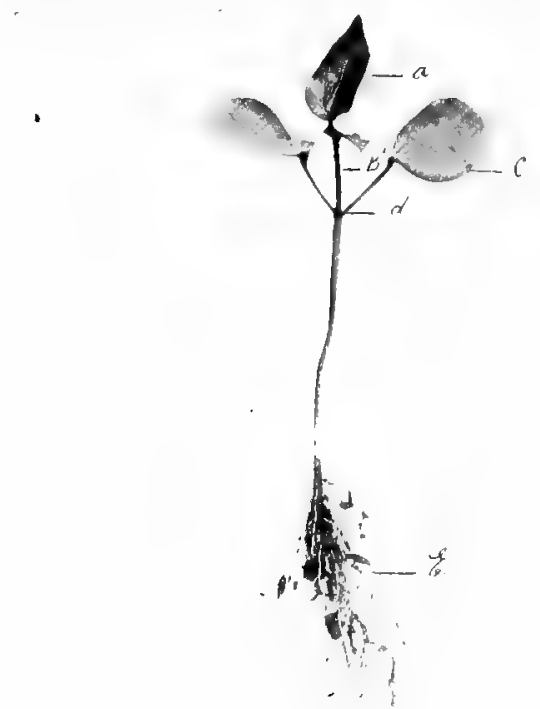

a First true leaves.

$b$ The true stem.

$c$ The cotyledons.

$d$ Primary axis.

$c$ Sccondary roots with root hairs. 
29-L.S., Root of Bean, "Faba yulgaris,"

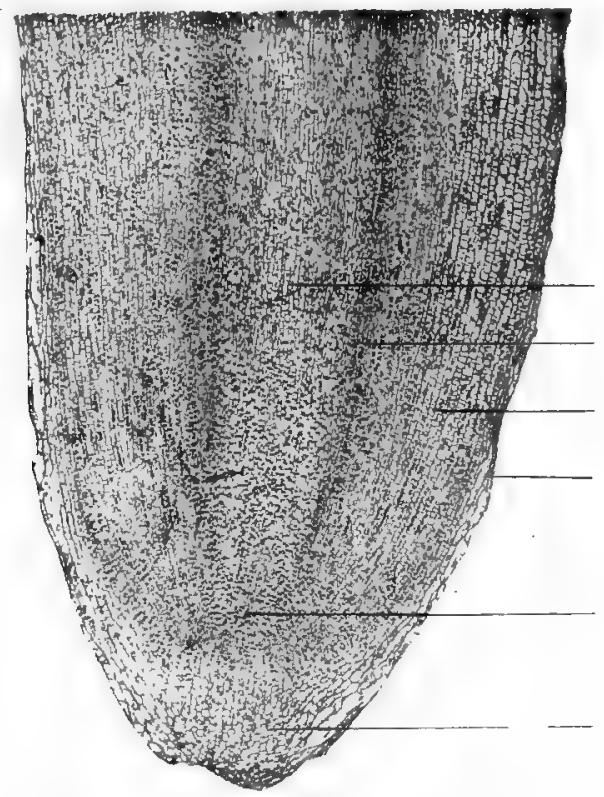

The Plerome, central axis.

The Endodermis.

The Periblem.

The Piliferous layer.

The Growing point.

The root-cap.

30. T.S., Root of Bean, "Faba vulgaris" (more advanced than 29).

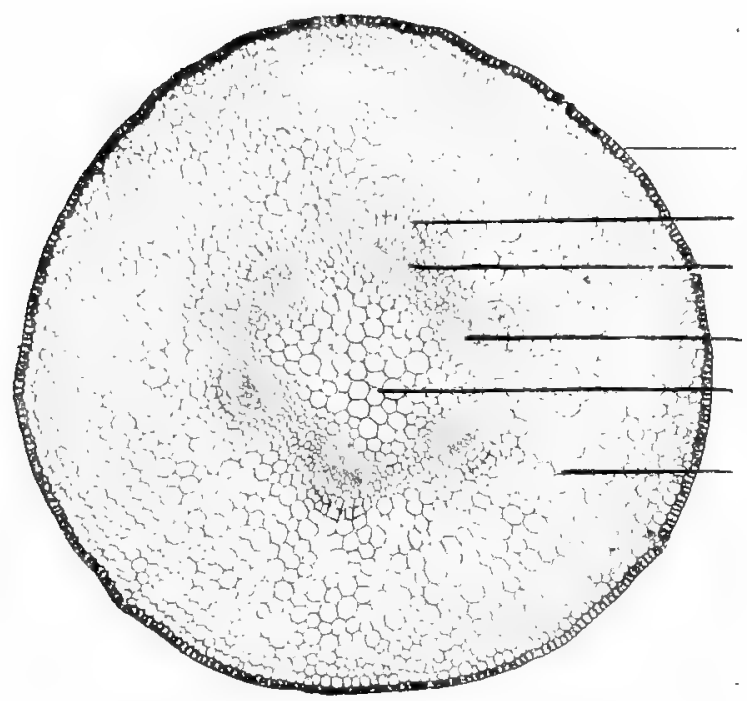

Cuticle.

Endodermis.

Pericycle

Wood elements developing Central axis.

Cortical tissue. 
31. T.S. Root of "Acorus Calamus."

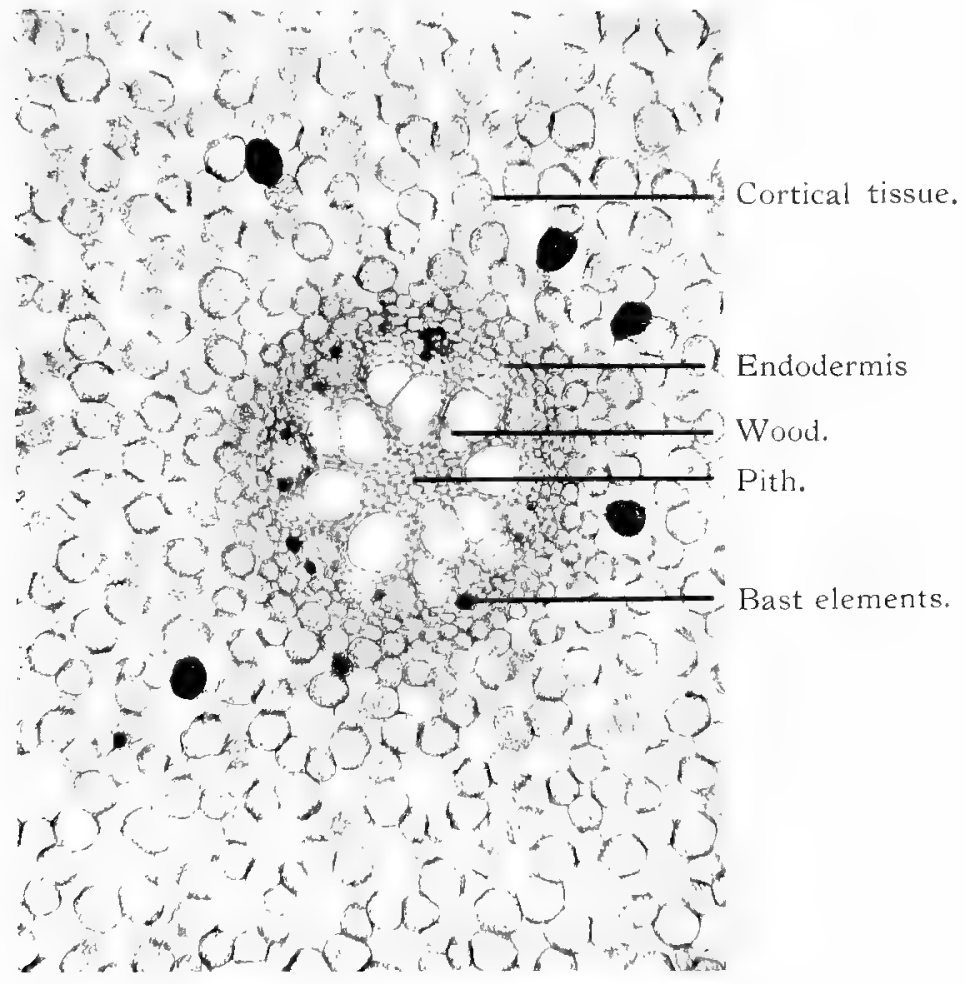

32.-L.S. Root of Onion, "Allium cepa."

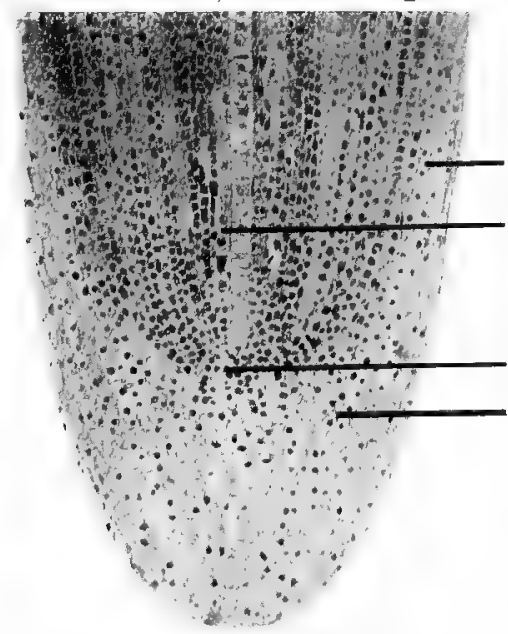

Piliferous layer.

Central Axis (plerome)

Growing point of root.

Root cap. 
II

2. $10 f_{3}$

$\rightarrow 0$ e

- 153 .

$\Rightarrow 0^{0} 0^{\circ}$

b.

- $b^{3}, 5$
33.-L.S. Root of Onion, "Allium cepa"

Part of $32 \times 200$ showing nucleus in various stages of division (Karyokinesis).

34.-T.S. Through Apical-cell of Root of Aspidium Filix-mas (Shield-fern.)

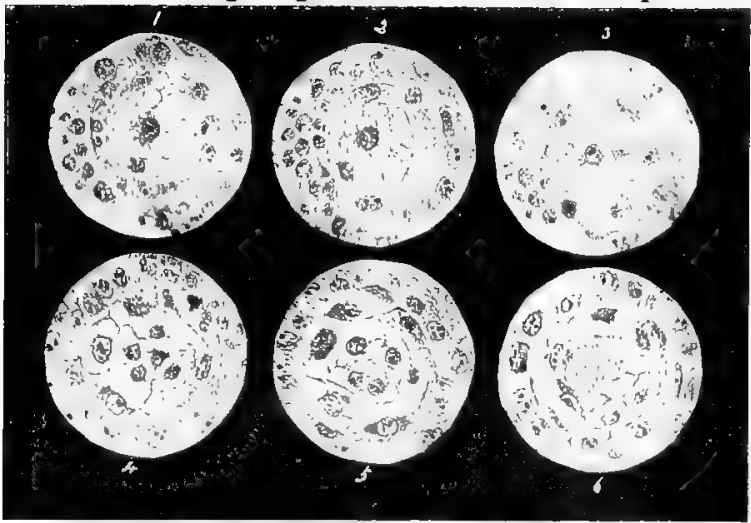

Sections 1-6, passing through the same cell at various planes in transverse direction.

35.-L.S. of Apical-cell of Aspidium Filix-mass (Shield-fern).

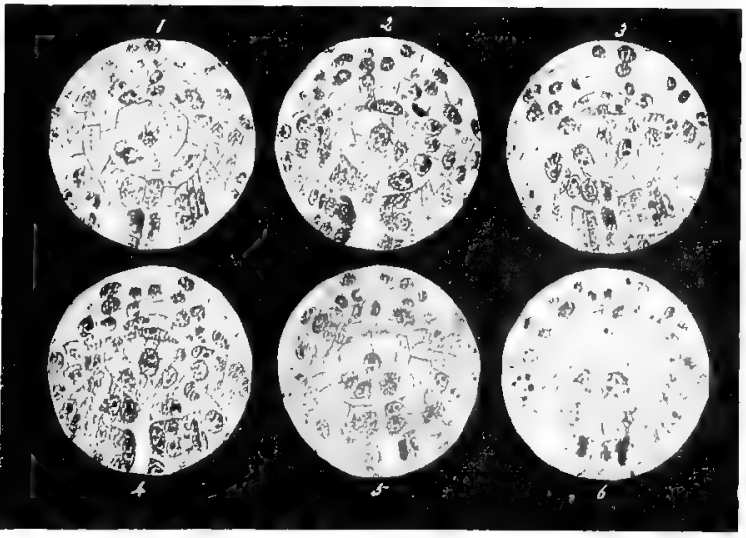

Sections 1-6, passing through the same cell at various planes in longitudinal direction. 
36. -T.S. Germinating radicales of a grain of Barley.

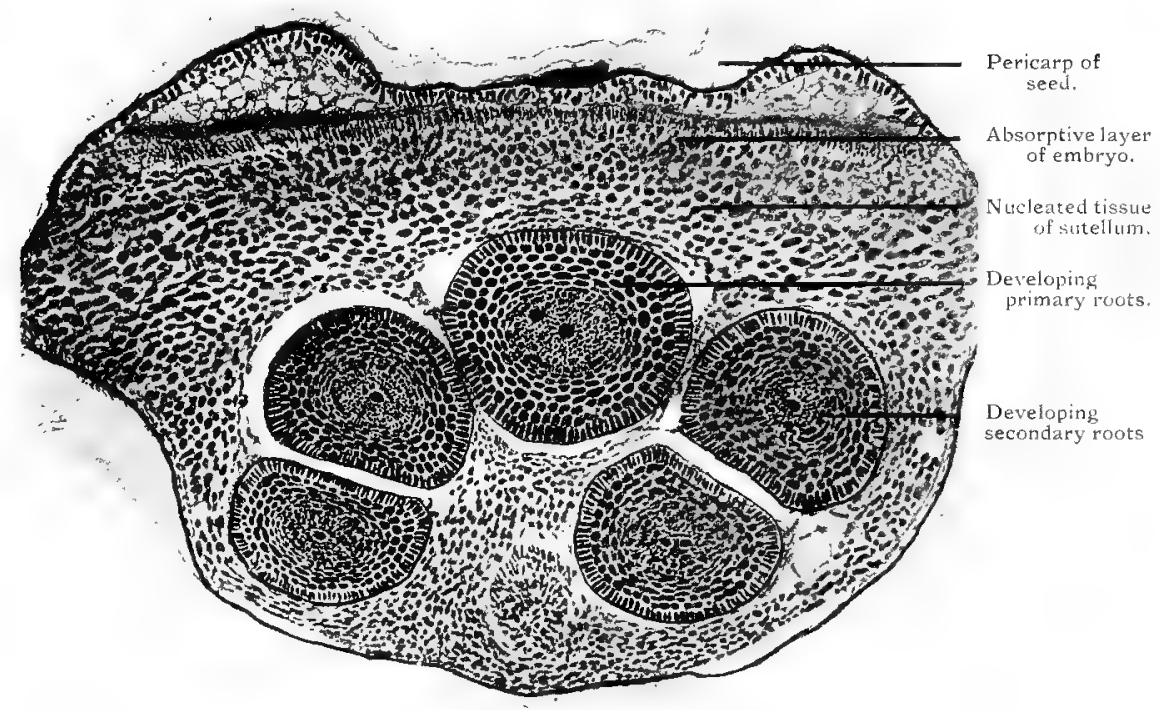

37.-Entire plant of "Lemna minor." (Common Duckweed).

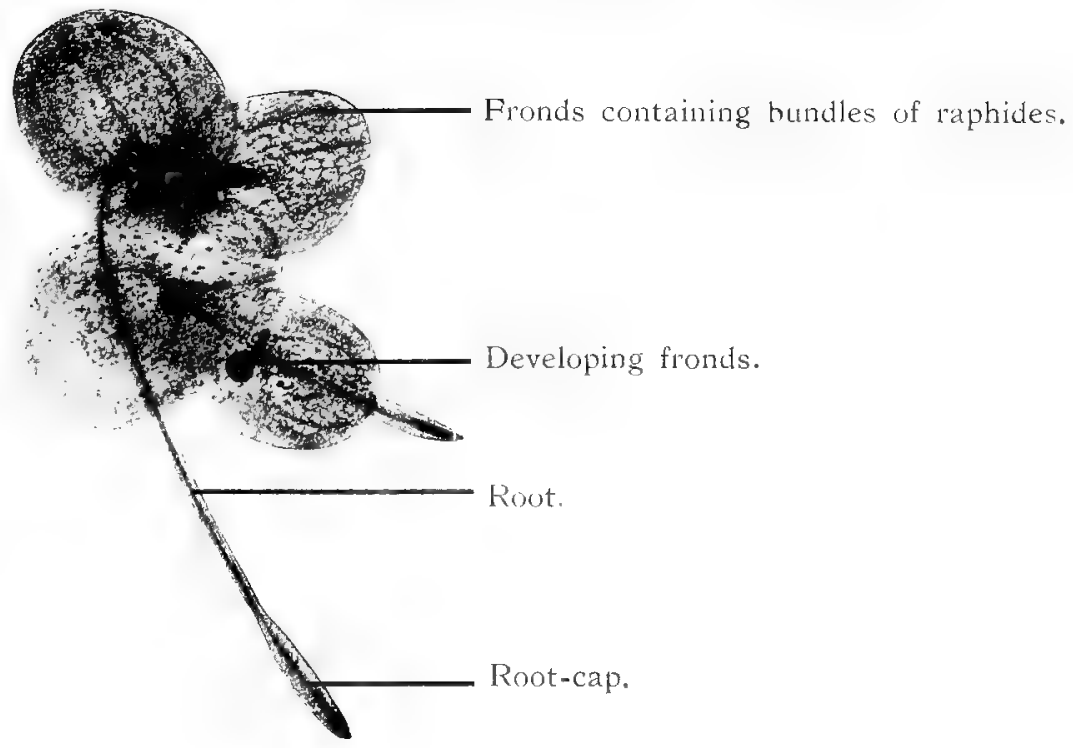


38. T.S. Roots of "Zea mais" Indian corn.

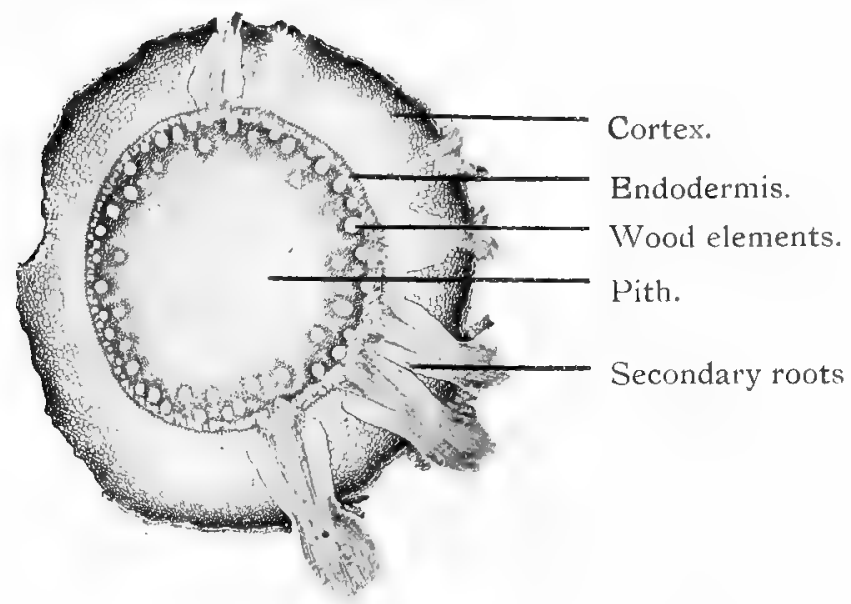

39. T.S. Stem of "Zea mais" Indian corn

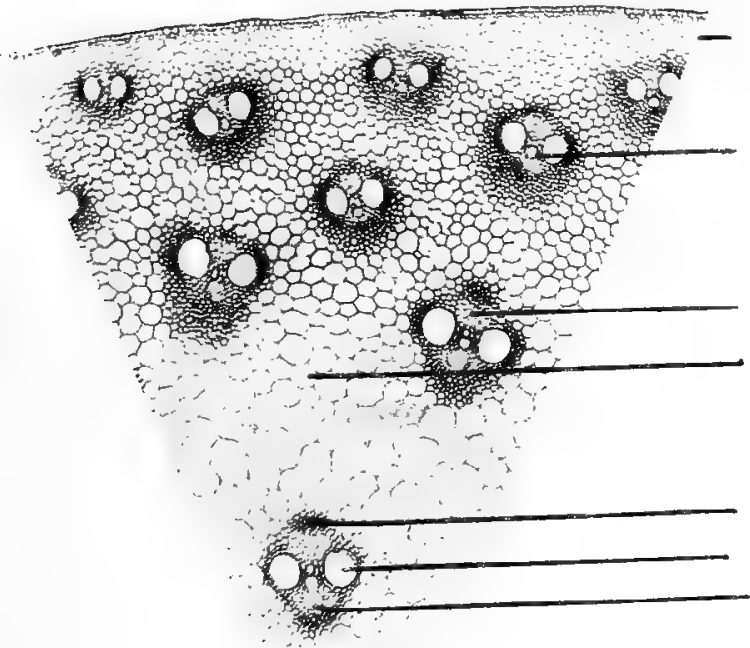

Epidermal tissue.

Vascular bundle.

Phloem of bundle.

Primary ground tissue.

Bundle sheath.

Pitted vessels.

Annular vessels. 
40.-L.S. Through a Vascular bundle of "Zea mais" Indian corn.

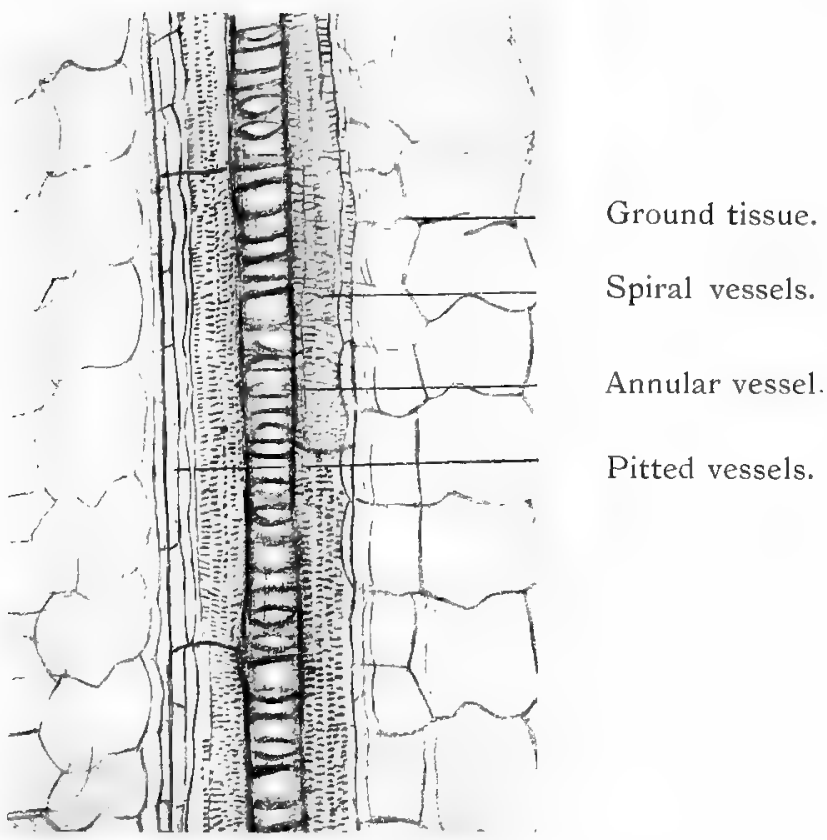

41. T.S. Stem of "Cordyline rubra" Dracœna.

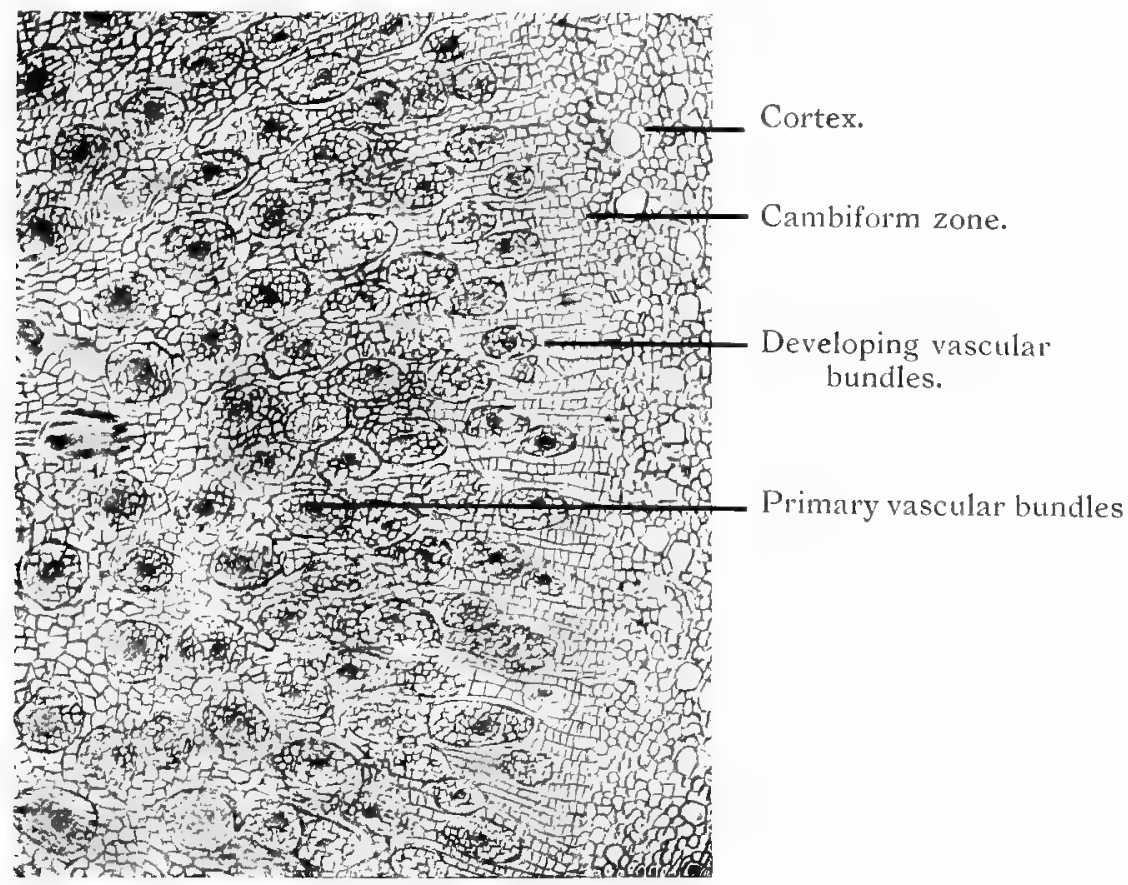


42. T.S. Stem of "Gossypium Sp." Cotton Plant.

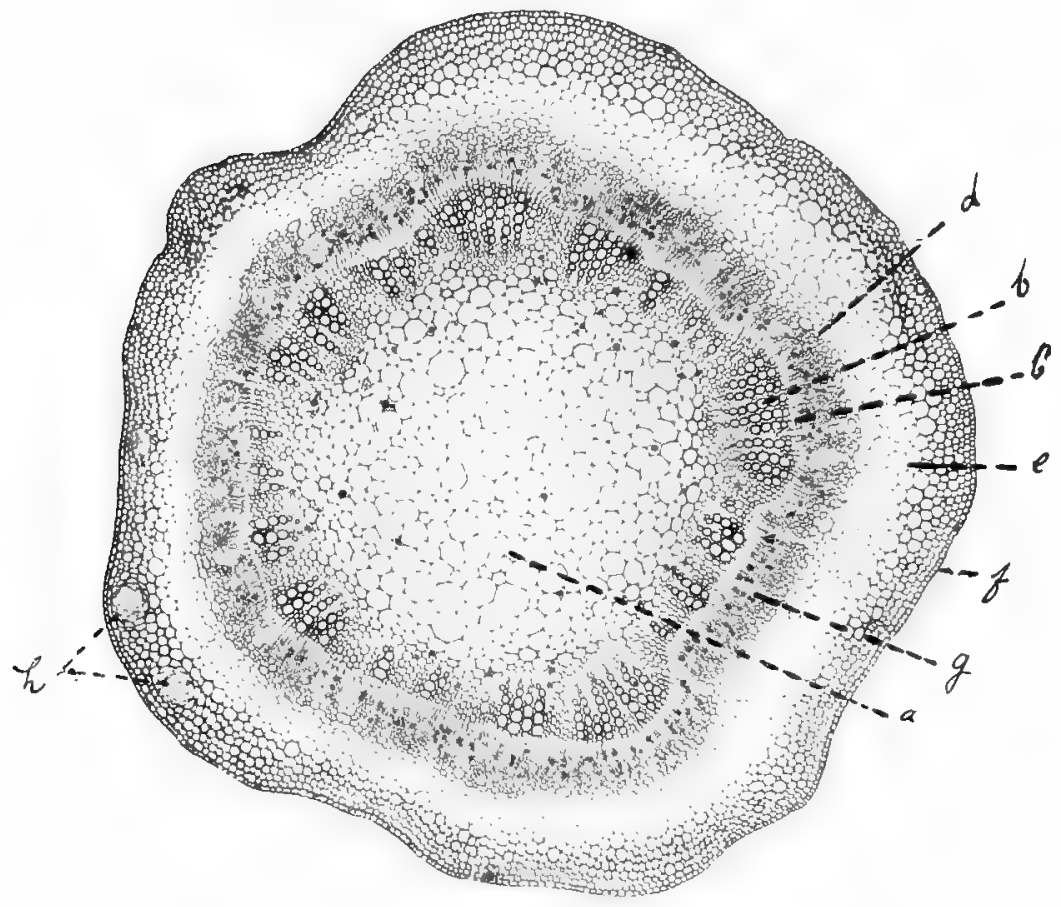

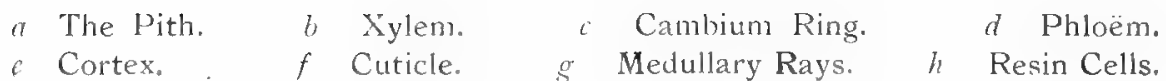


43. -T.L.S. Stem of "Gossypium Sp." Cotton Plant.

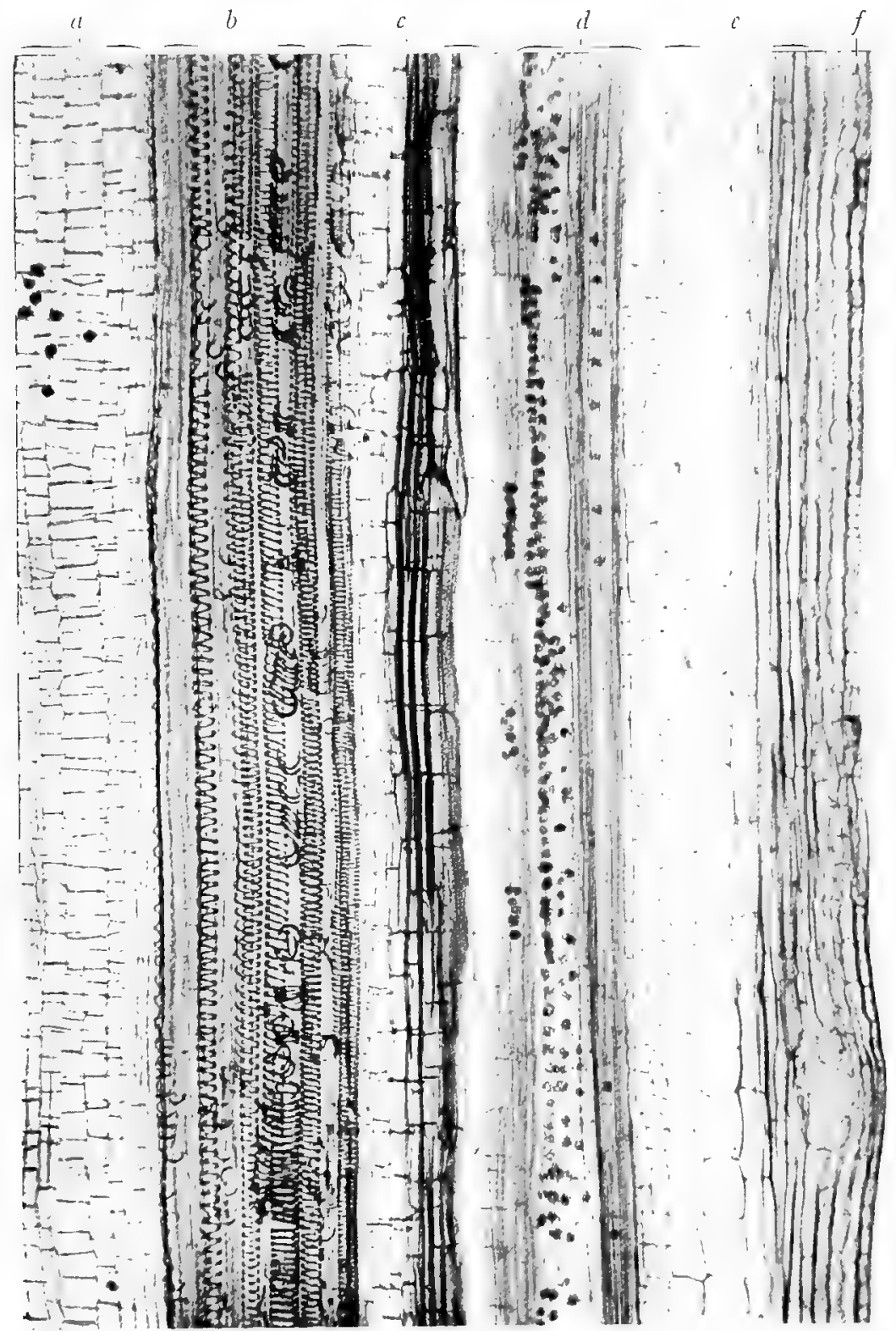

a Pith.

b Spiral Vessels.

Cambium.

d Phoem,-containing Cluster Crystals. e Cortical Tissue. $f$ Cuticle. 
44.--T.S. Stem "Hippuris vulgaris," Mare's-tail (Aquatic type).

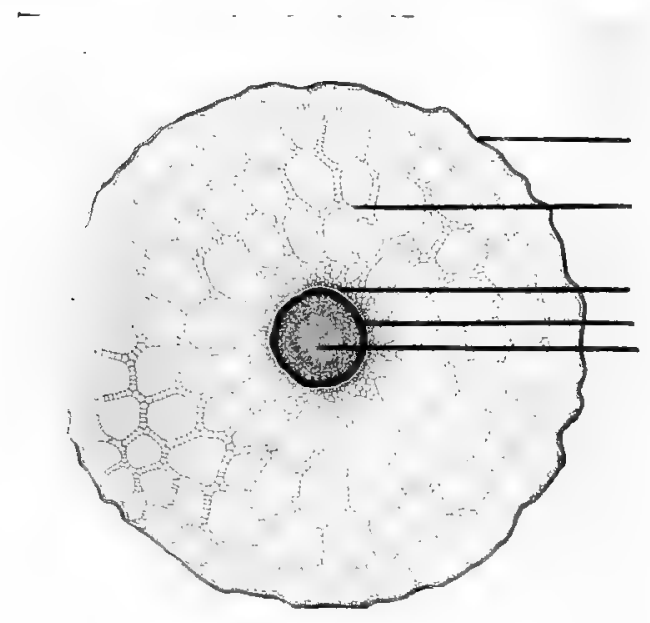

Epidermis.

Cortical tissue.

Phloem of bundle.

Xylem (wood).

Central axis.

45. -.-L.S. Stem, “ Hippuris vulgaris,” Mare's-tail

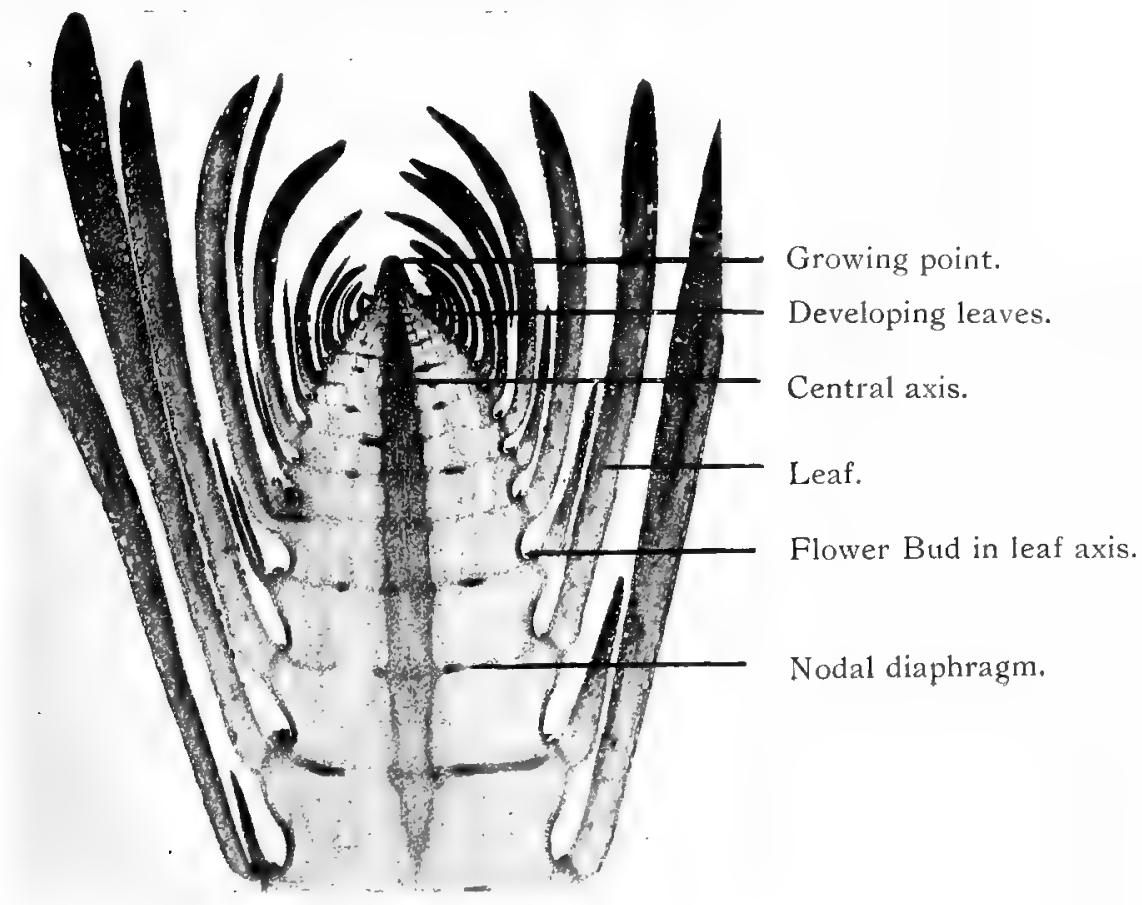


46.--T.S. Stem, "Limnanthemum nymphæoides," Lymnanth (Aquatie type).

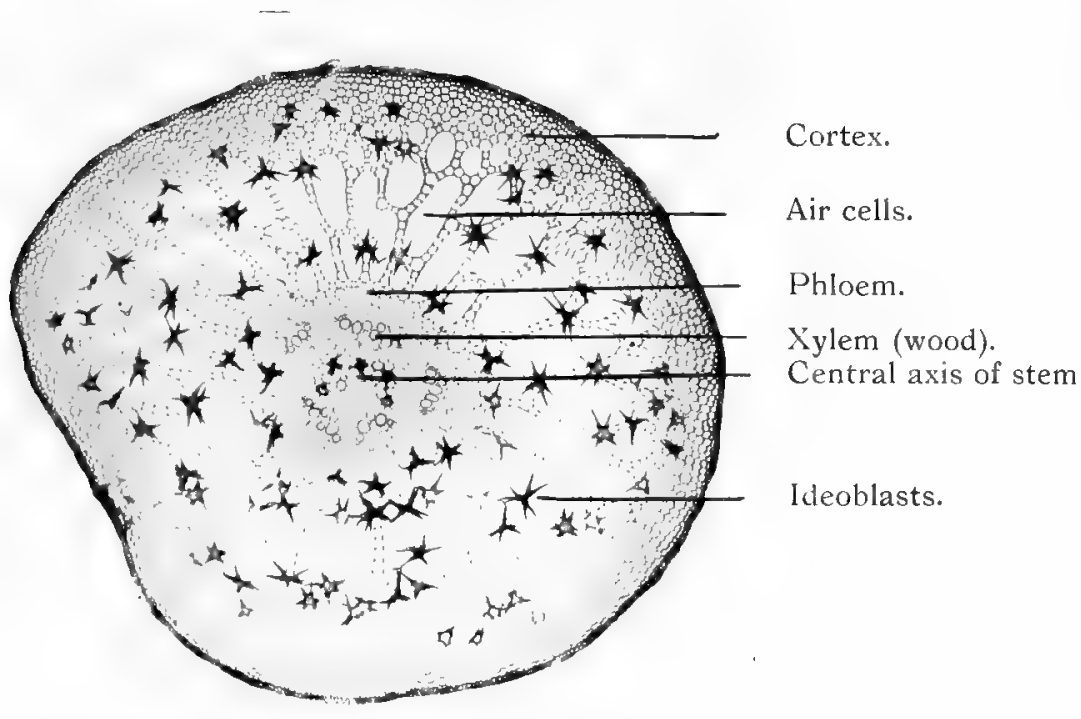

47. - T.S. Stem, "Tamus communis," Common Tamus.

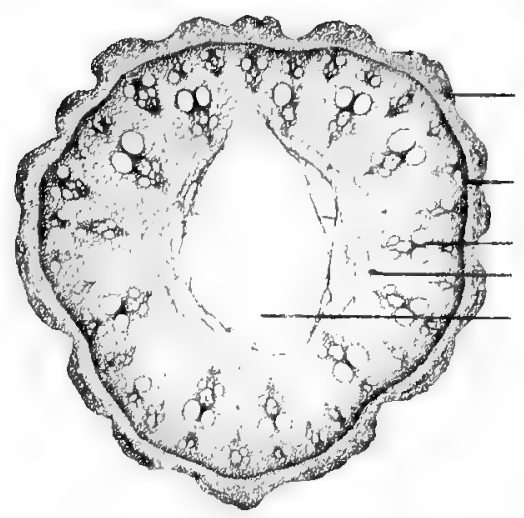

Epidermis.

Sclerenchymatous ring.

Xylem (wood vessels).

Ground tissue.

Central cavity of stem. 
48.-T. \& L.S. Stem of "Cucumis sativus," Cucumber.

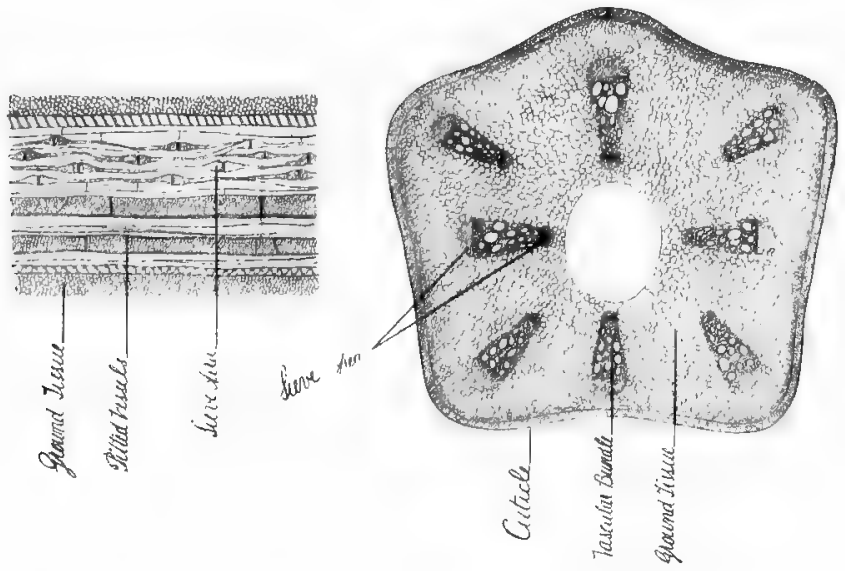

49.-T.S. Stem, "Helianthus annuus," Sunflower.

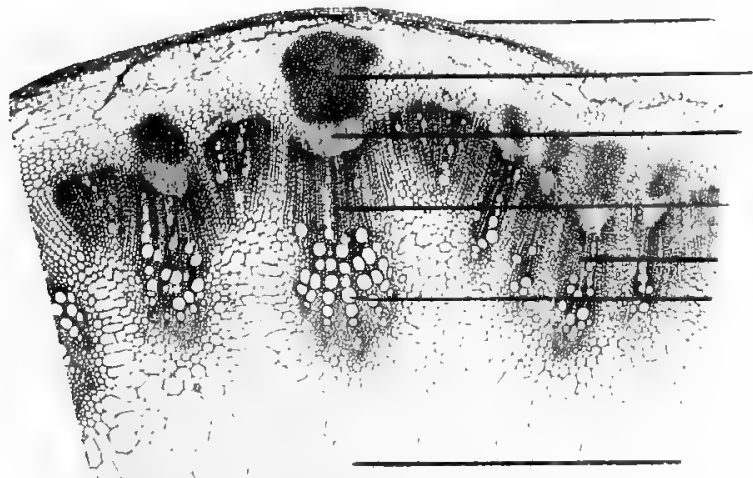

Epictermis

Phloem elements.

Cambium ring.

Xylem bundles

Secondary bundle.

Spiral vessels of primary bundle.

Ground tissue 


\section{0.--T.L.S. Stem, "Helianthus annuus" Sunflower,}

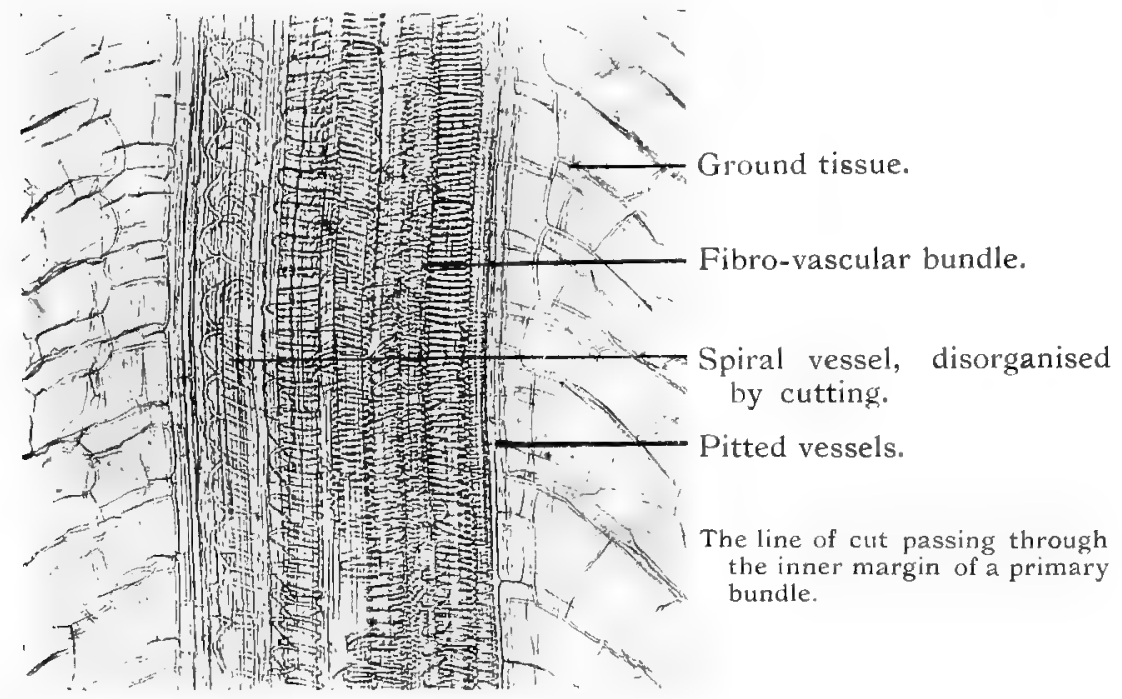

51.-T.S. Stem, "Tilia europœa," Lime tree.

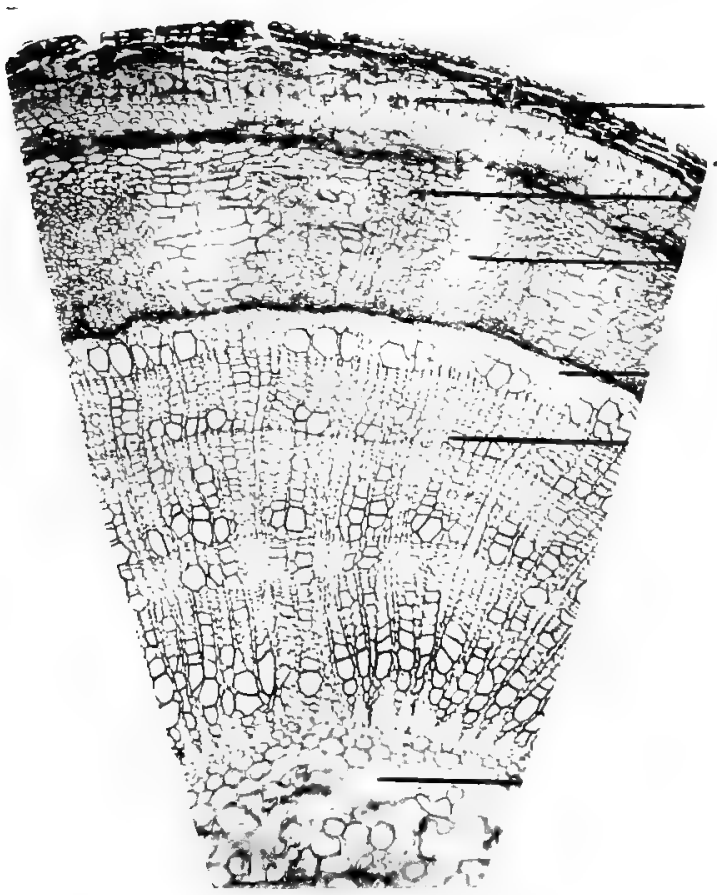

Cortical tissue.

Phloem (bast cells).

Medullary ray.

Cambium ring.

Xylem, (Wood) of three years' growth.

Pith, 
32.-T.L.S. (Bast Area) Stem of "Tilia europœa," Lime tree.

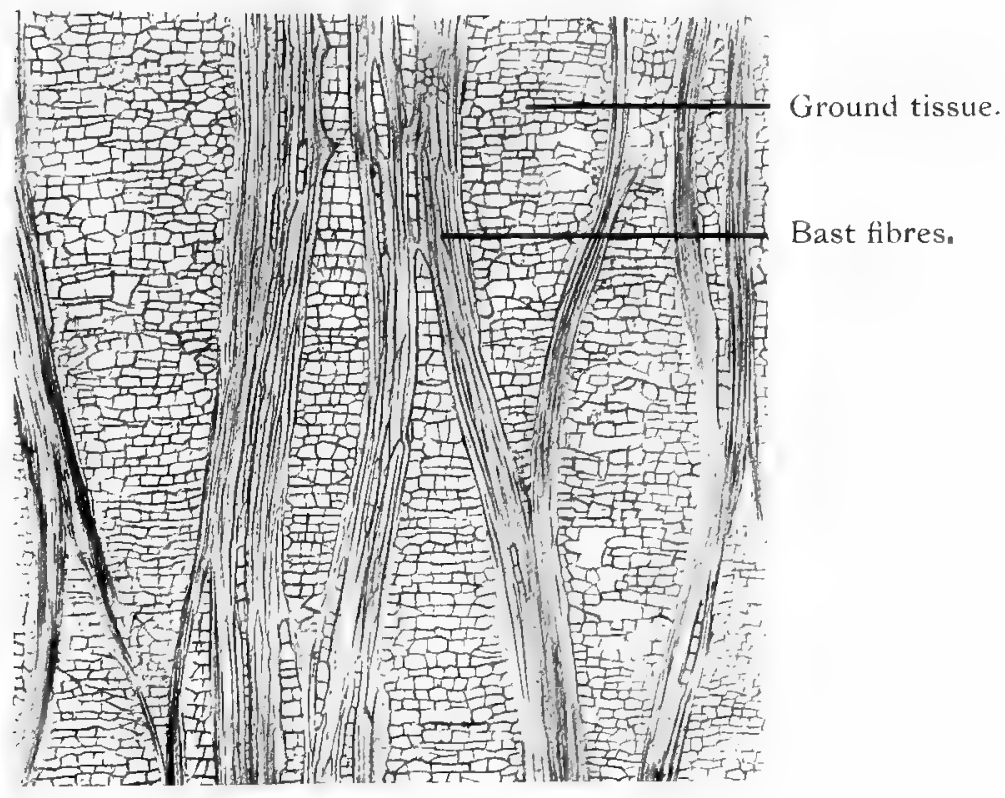

53.-T.L.S. (Wood Elements) Stem of "Tilia europoea," Lime tree.

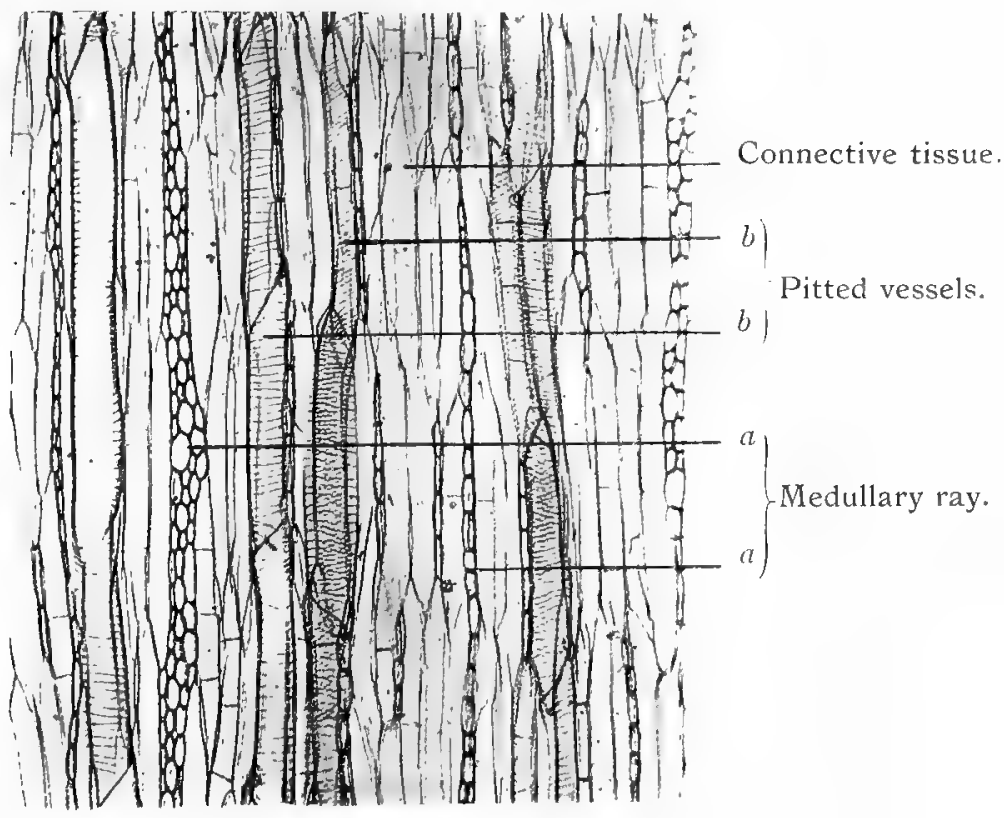


54. T.S. Root, "Pinus sylvestris." Common Pine.

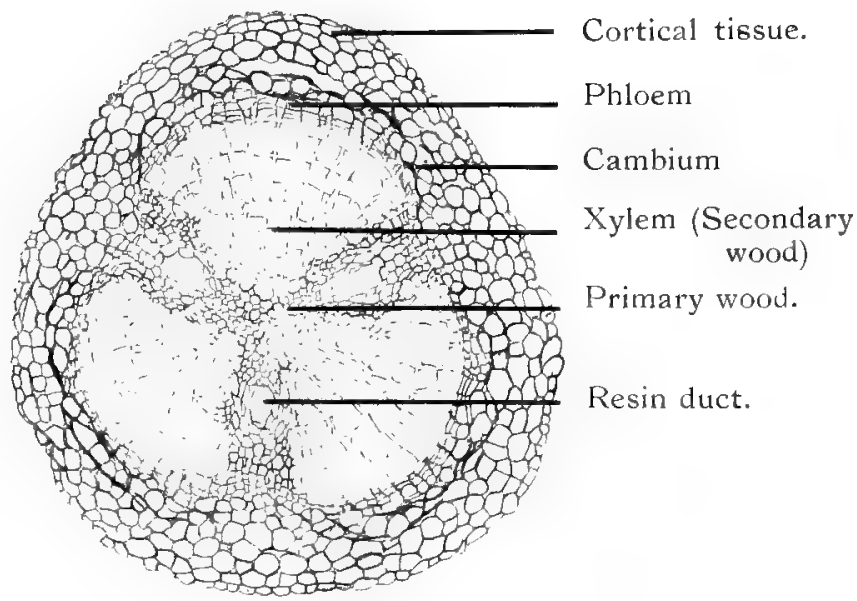

55. - L.S. Growing point of stem, "Pinus sylyestris," Common Pine.

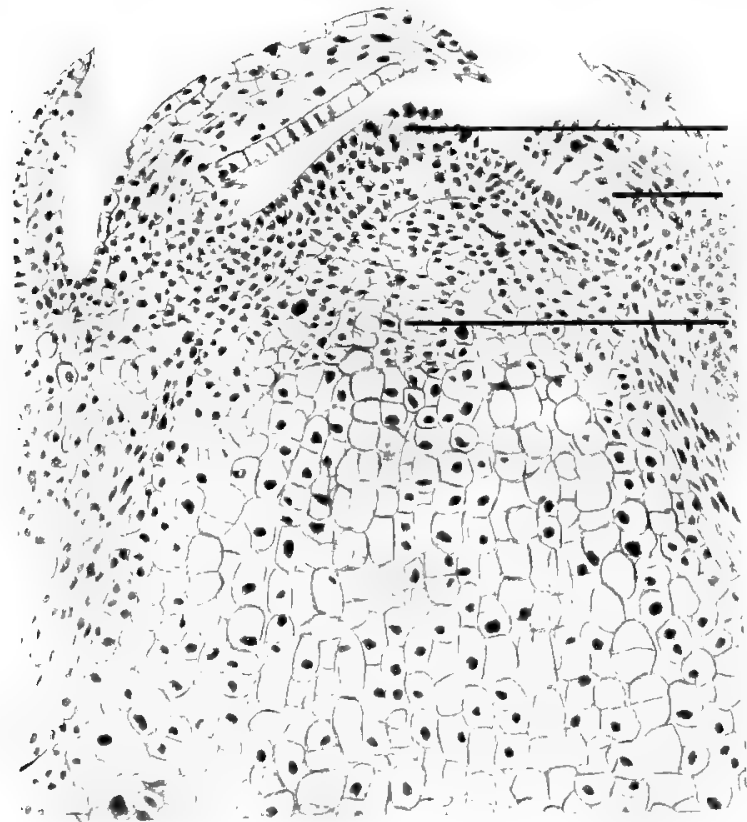

Growing point of stem.

Axiliary buds in development.

Meristem tissue in active state of division 
56.-T. S. Young Stem, "Pinus sylvestris," Common Pine.

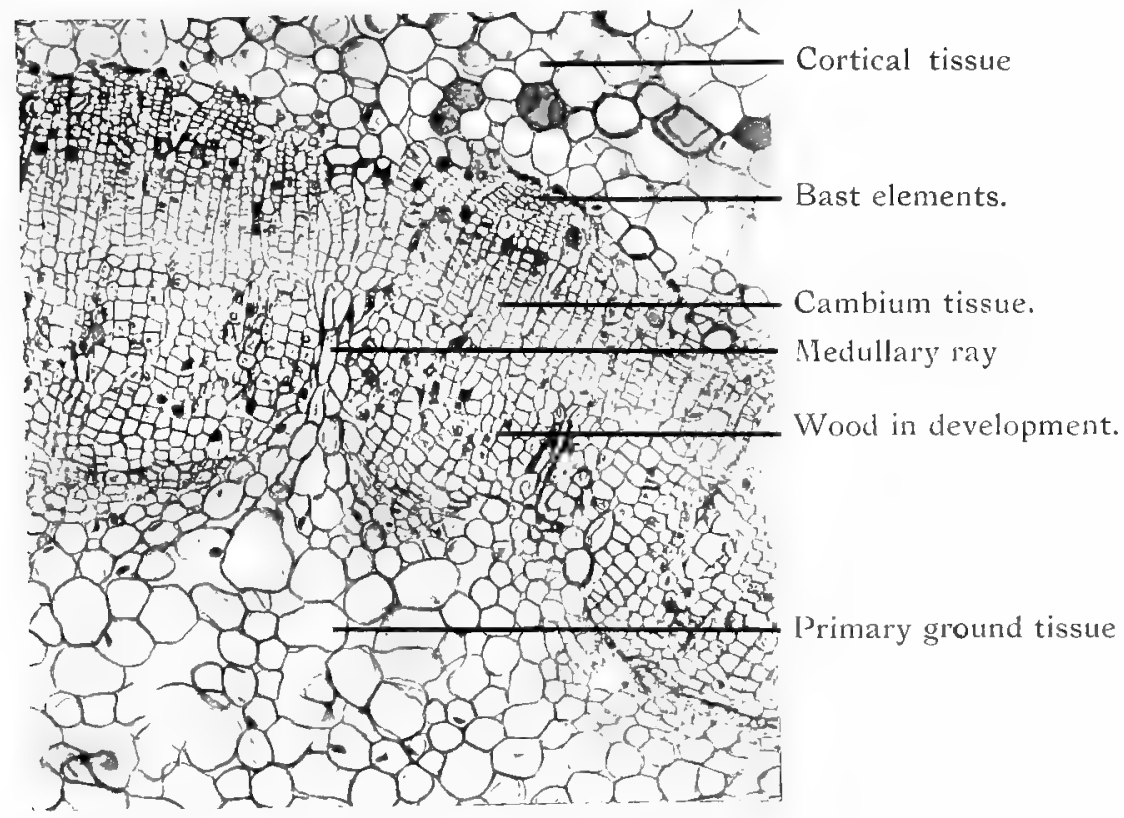

57.-Advaneed stage, Stem of "Pinus sylvestris," Common Pine.

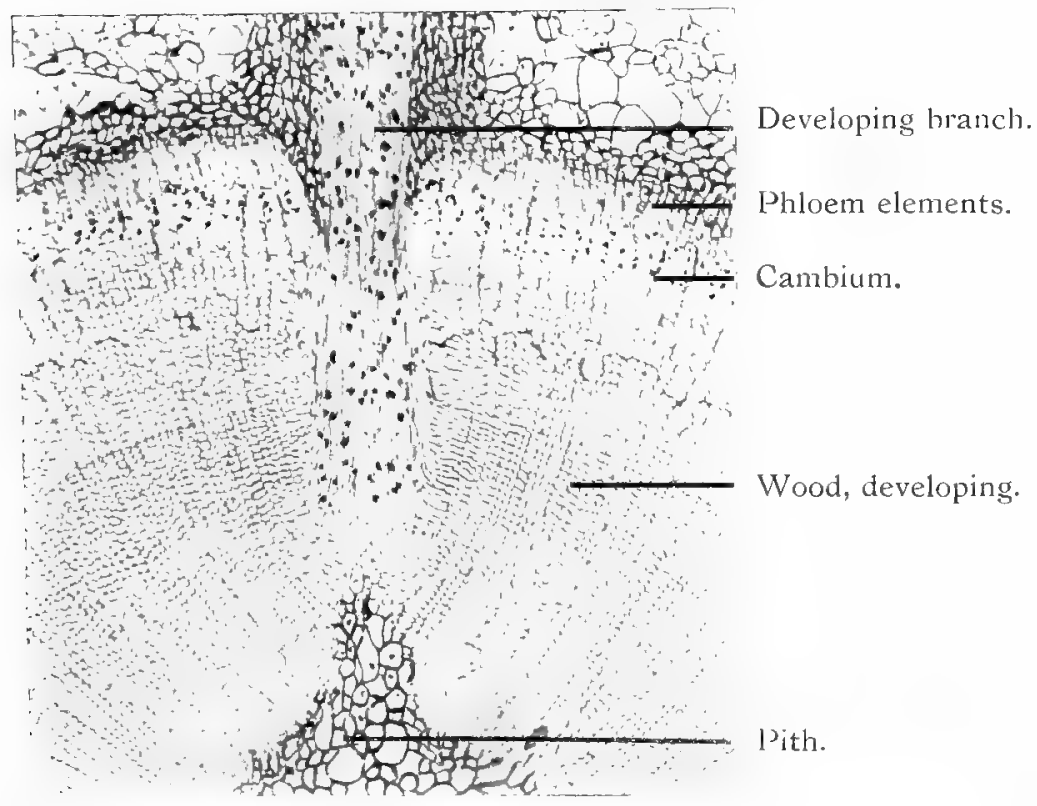


58.-L.S, Advanced Stage of Stem, "Pinus sylvestris."

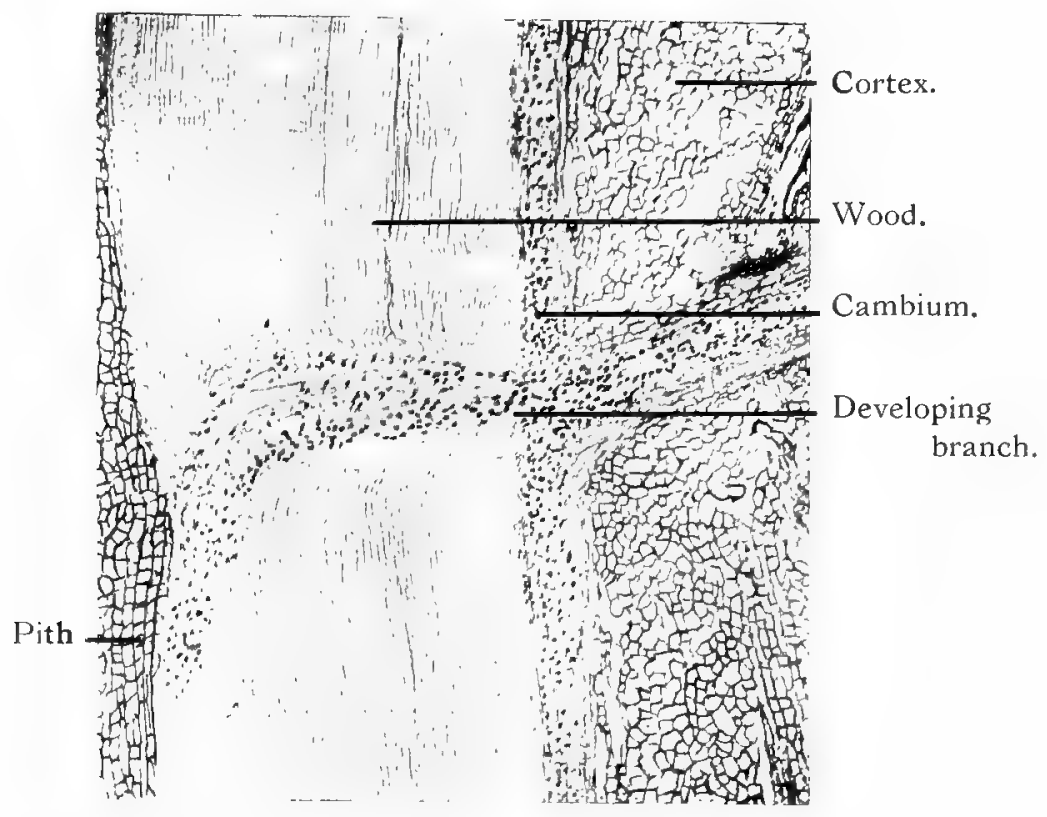

59.-T.S. Resin Passage of Stem, "Pinus sylvestris."

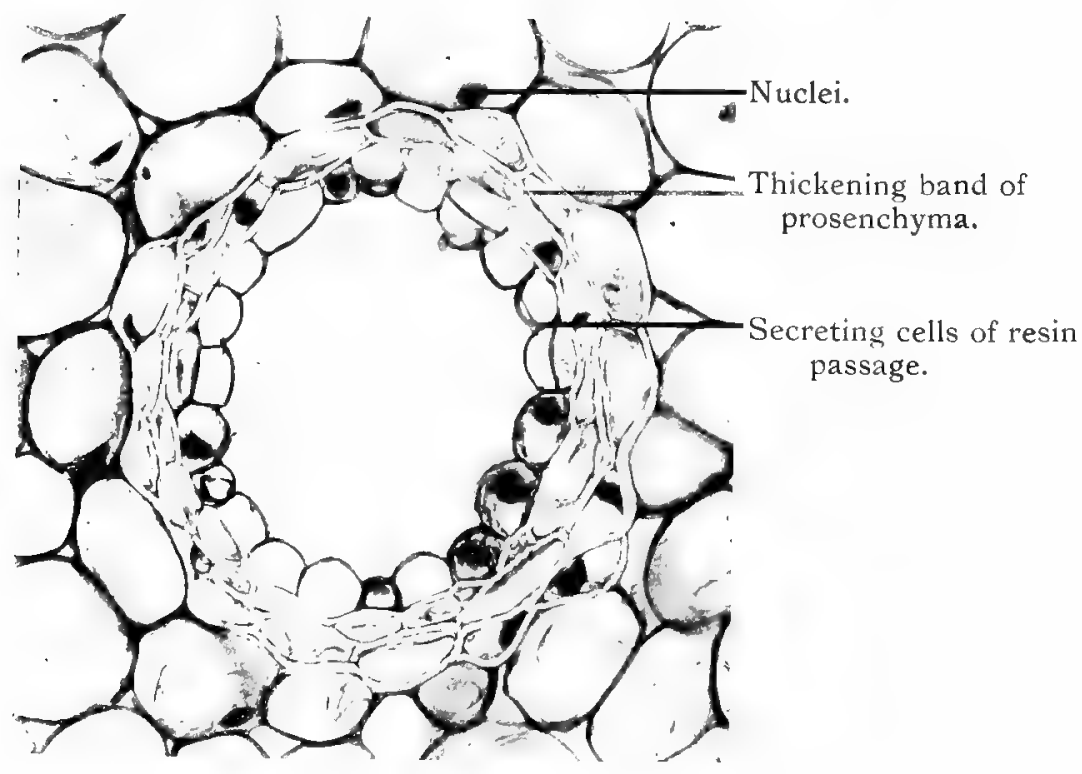


60. -T.S. Leaf of "Pinus sylvestris," Common pine.

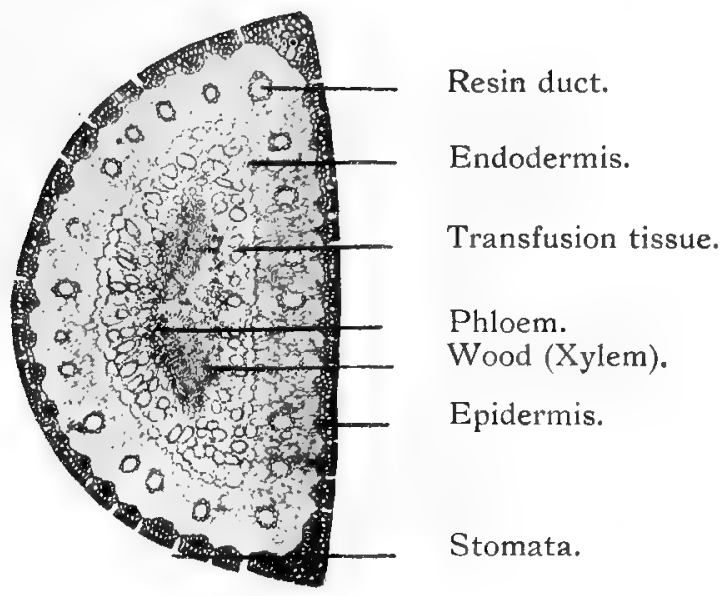

61.-L.S. Male Cone, "Pinus sylvestris," Common pine.

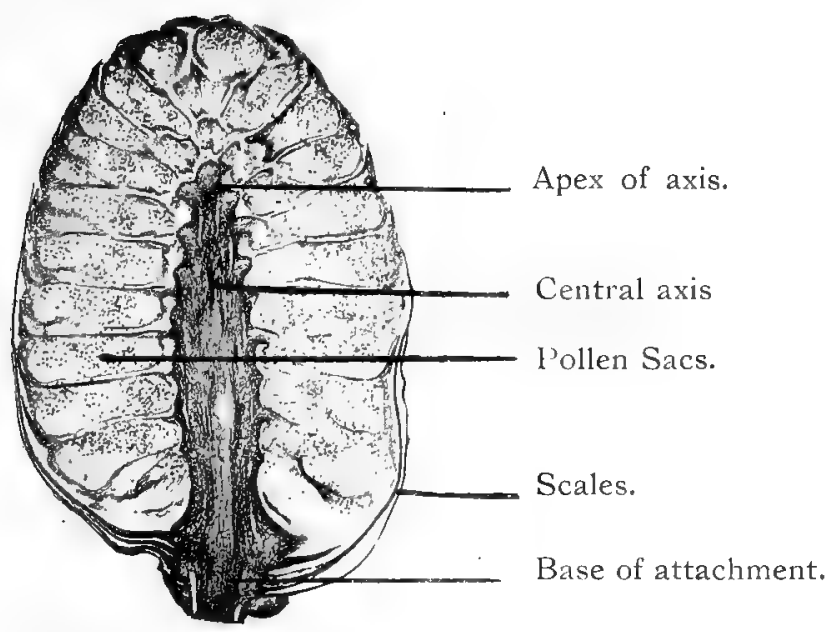


62. Pollen from Male Cone of "Pinus sylvestris."

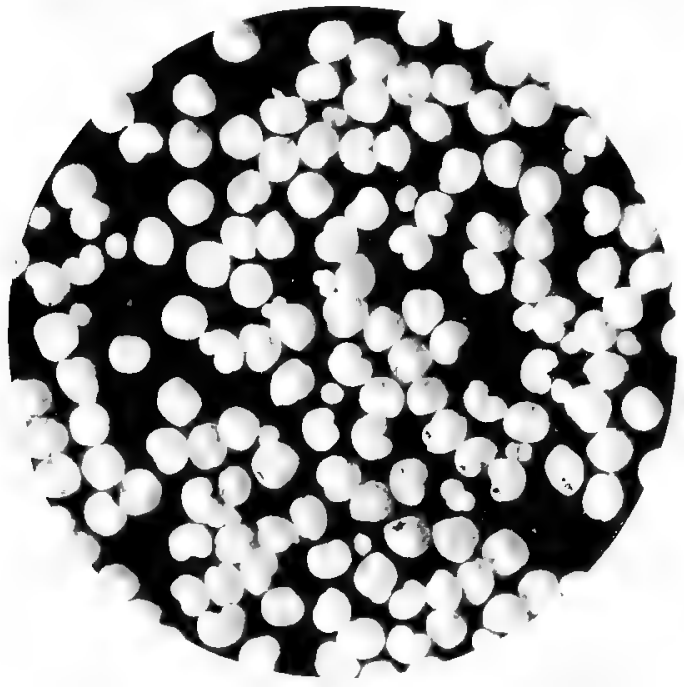

Fully developed pollen grains, showing wing or air sac, taken from mature cone.

63.-L.S. Developing Ovule, "Pinus Sylvestris."

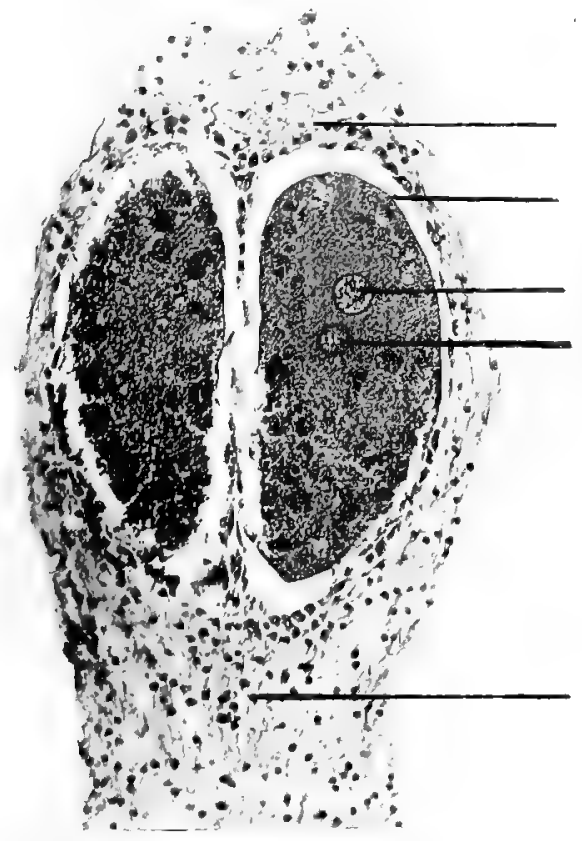

Integument.

Endosperm.

Spermo-nucleus.

Oonucleus.

Wing of seed. 
64.-T.S. Mature Ovule, "Pinus sp.," Pine Tree.

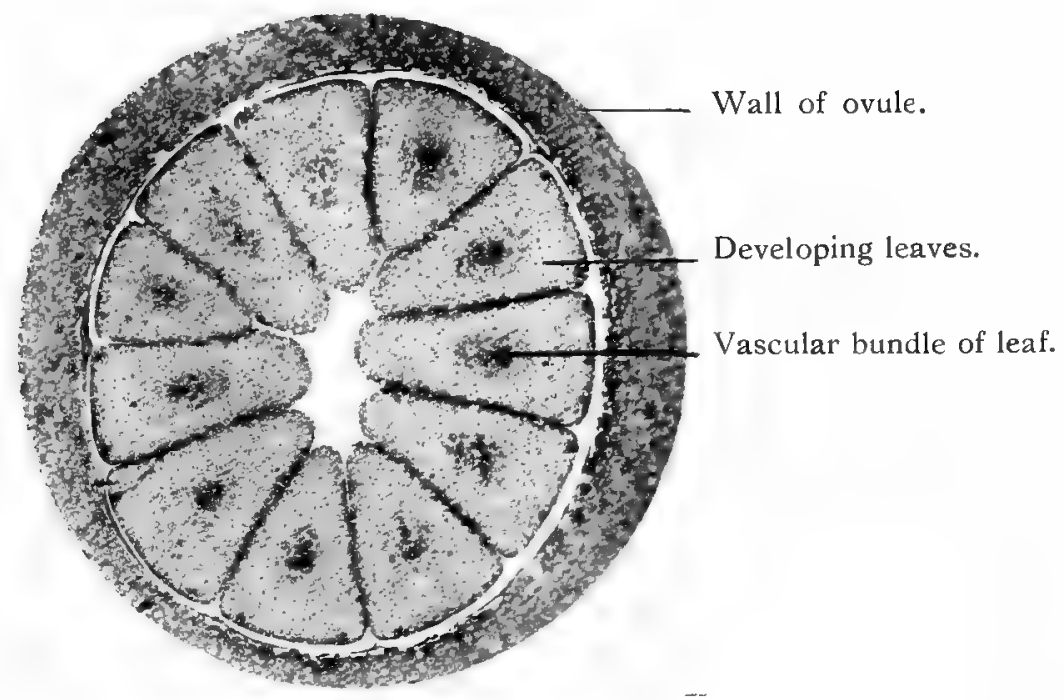

65.--T.S. Stem (Timber), "Pinus sylvestris," Common Pine.

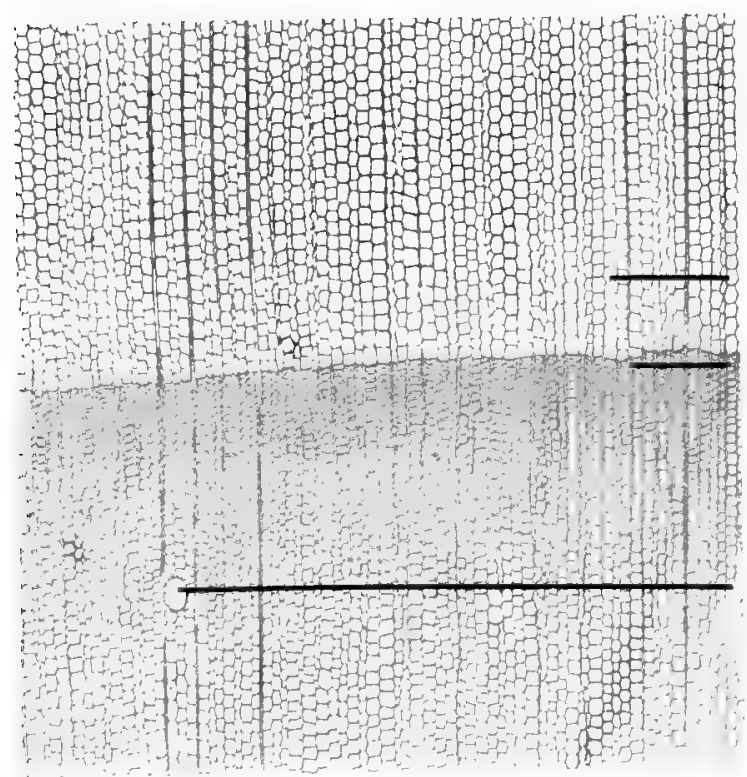

Spring growth of wood.

Autumn and winter growth.

Resin Canal. 
66.-R.L.S. Stem (Timber), "Pinus sylvestris," Common pine.

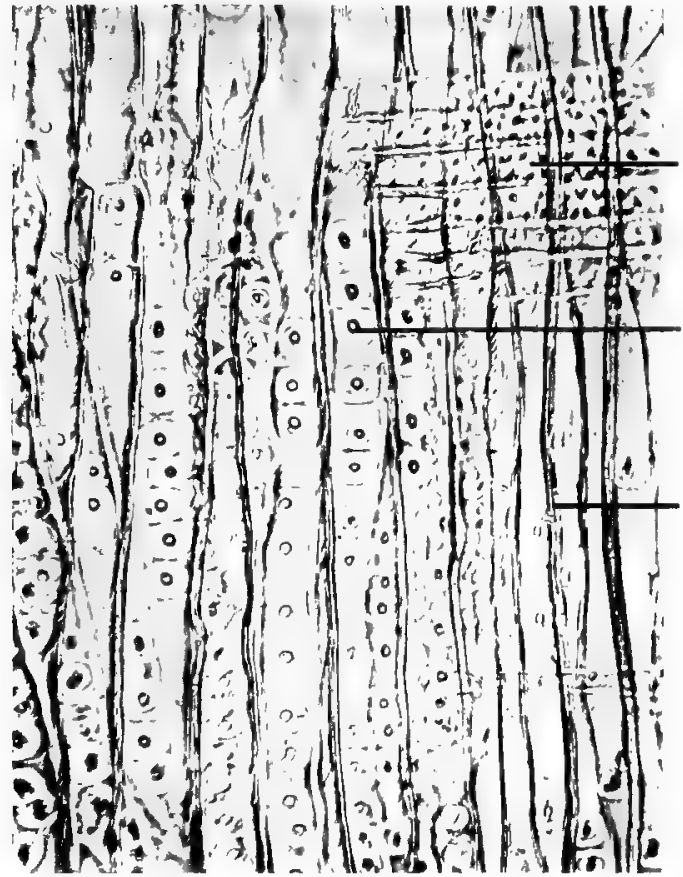

Medullary rays.

Bordered pits.

Cell-wall in radial view.

67.-T.L.S. Stem (Timber) " Pinus sylvestris," Common pine.

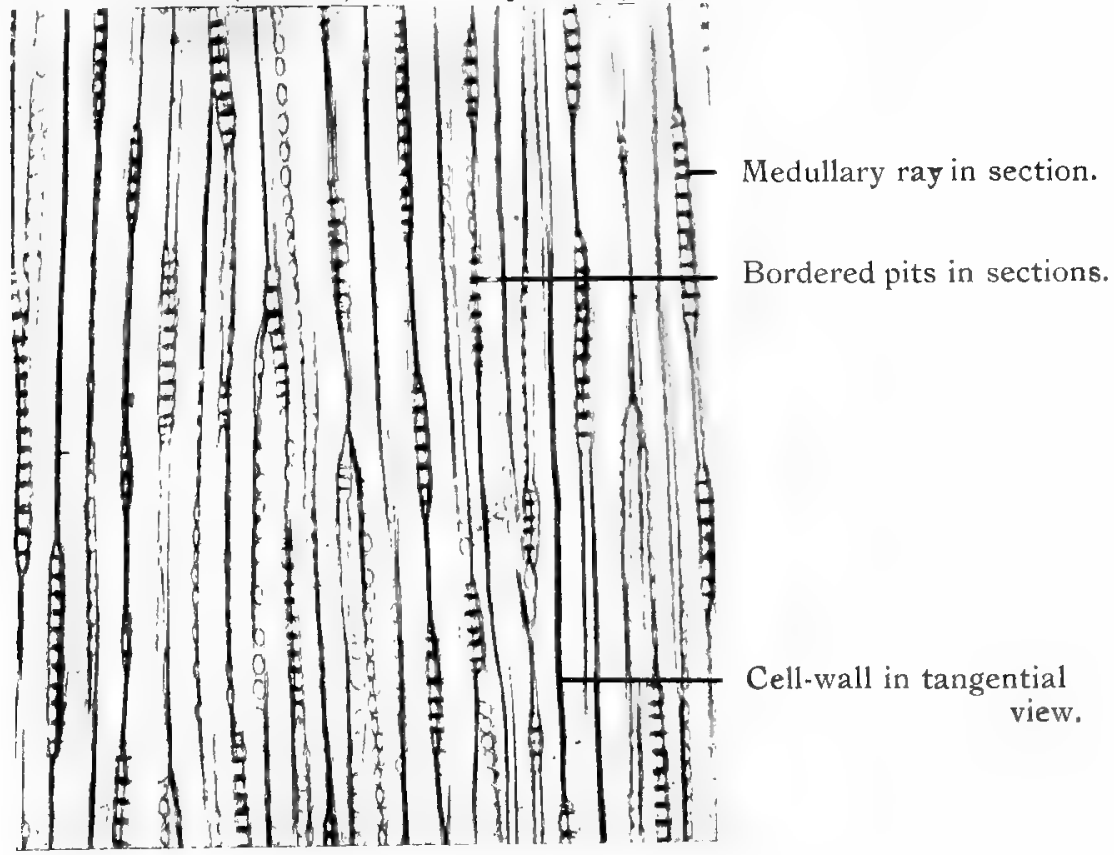


68.-Cuticle of Leaf, "Auricaria imbricata," Monkey-puzzle.
(i) (i)
(5)
a 0
c. 0
(i) (o) 0
(d) 0,0
o b a o 00
(1) 00
(a) 0
(4) 00
(a) 0 (a) 0
0. 0 0 0 0 0
(c) 0 o 0 (0)
(1)
(10) $\frac{00}{00}$
Cuticularised tissue.
0
(6) 0.000
(1) $\frac{0}{0}$ Stomata

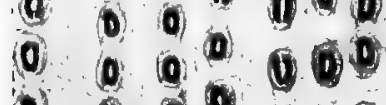
$0,0,0$
a o o o 0

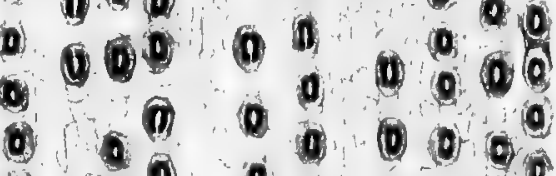
(1) 00000

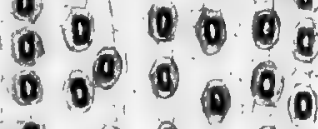

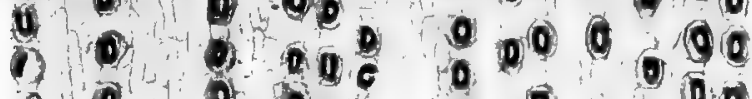

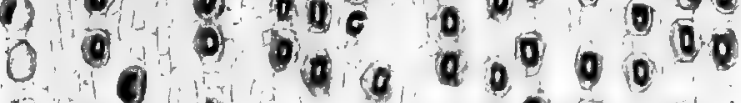

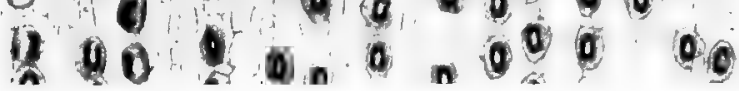

69. -Vascular System of Leaf of "Potentilla fragariastrum," Mock-strawberry.

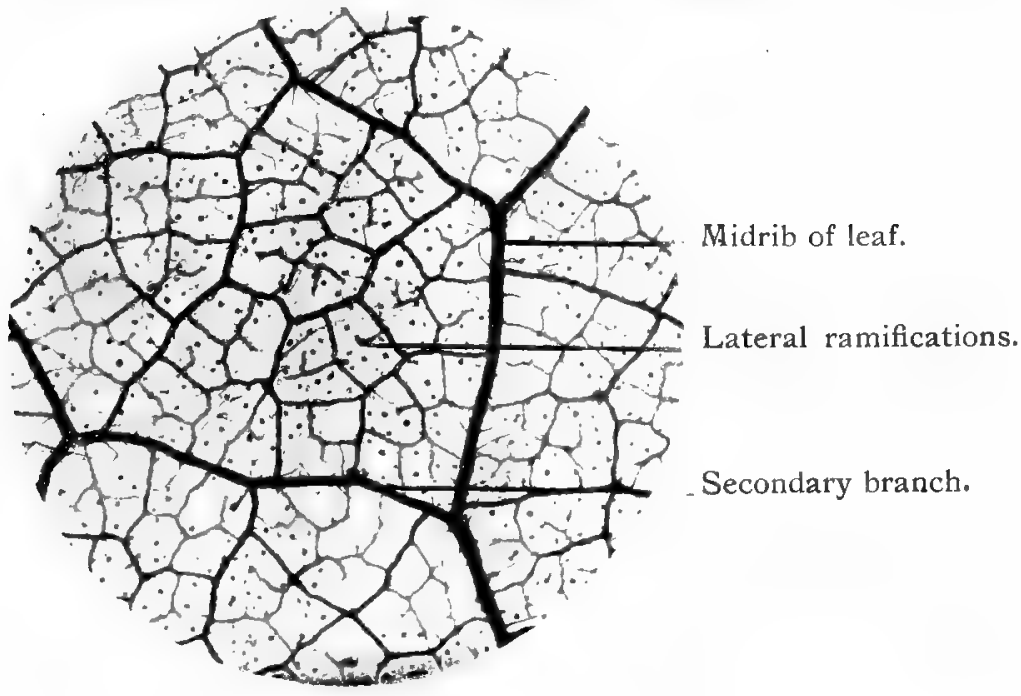


70.-T.S. Leaf of "Metrosideros verni," Bottle-brush Shrub.

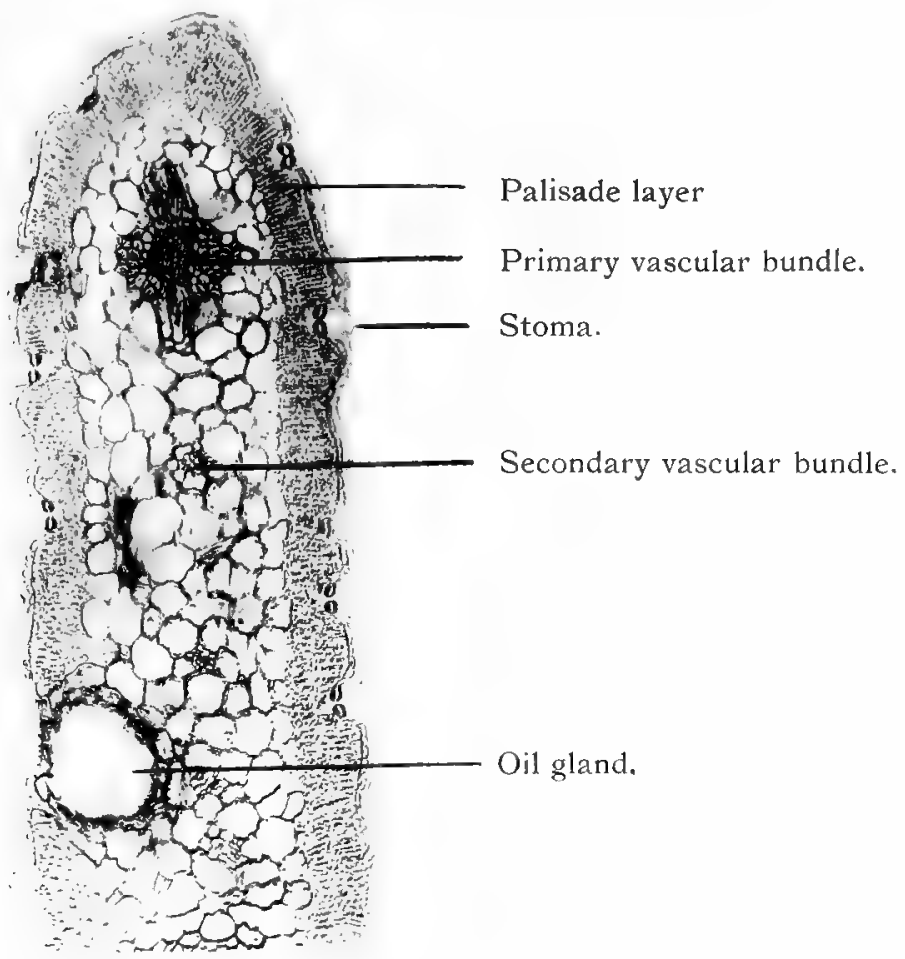

71. -Entire Sting of "Urtica dioica," Common Nettle.

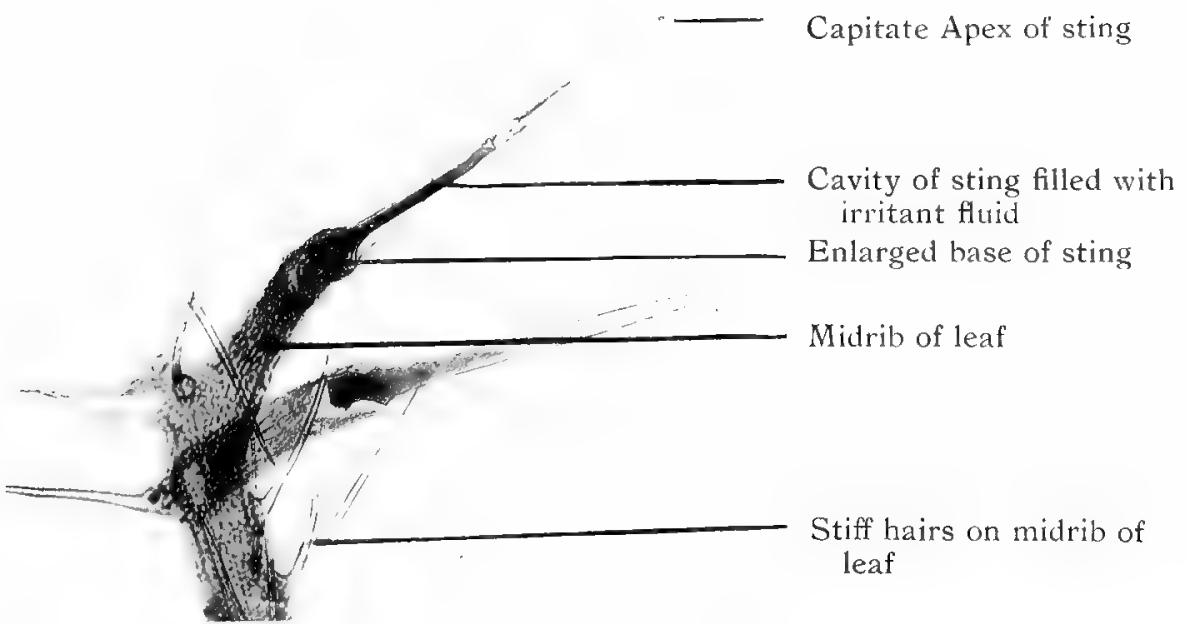


72.-T.S. Phylode of "Acacia decurrens," Wattle bark-tree.

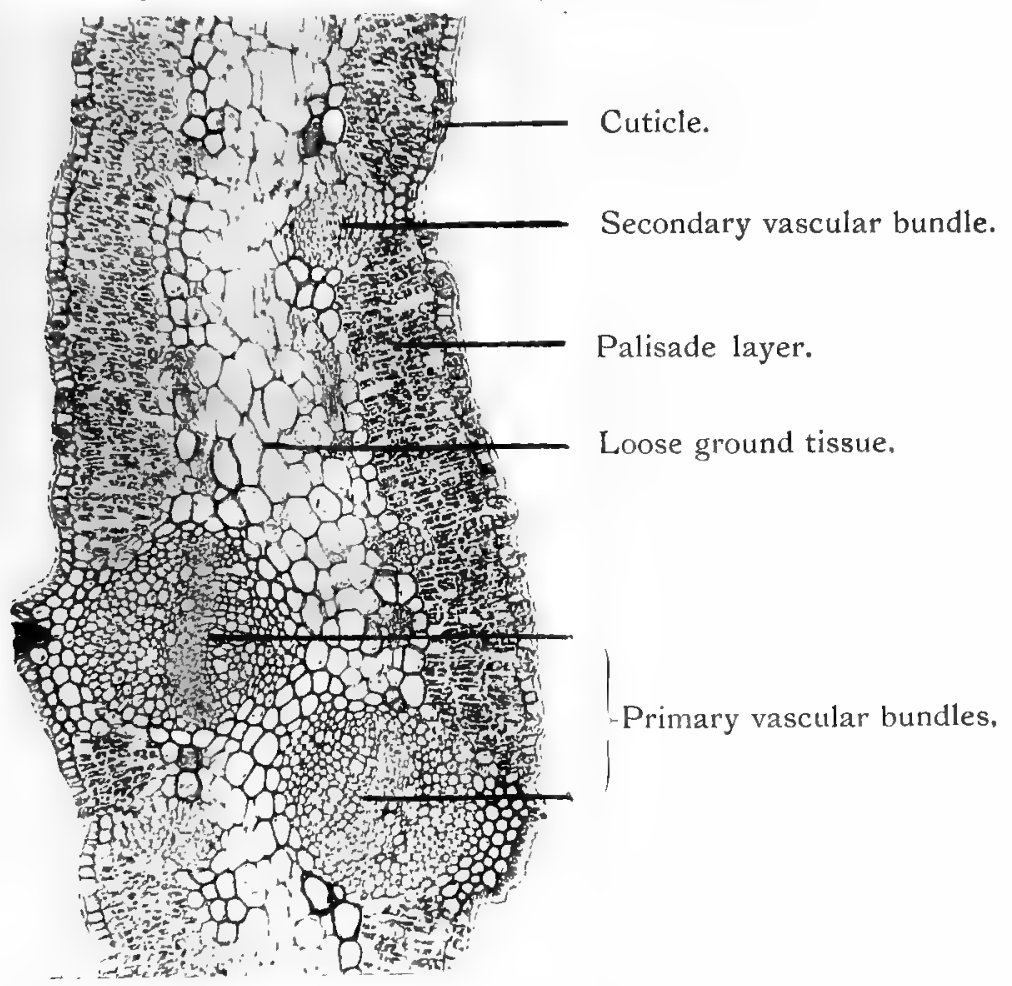

73.-T.S. Green Stem of " Casuarina equisetifolia," Switch-broom.

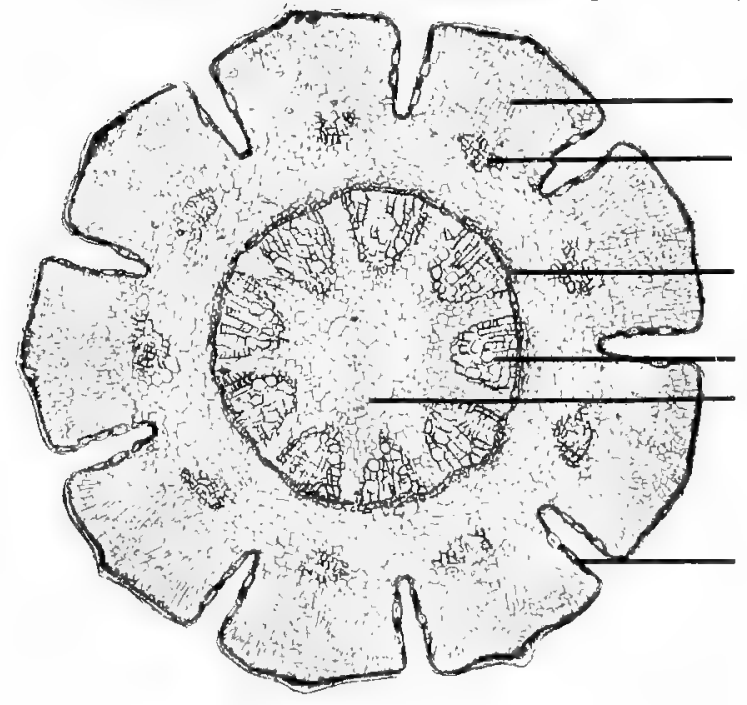

Cortical tissue.

Leaf-trace bundle.

Cambium ring.

Wood bundles,

Central axis of pith.

Stoma in furrow. 
74.-T.S. Leaf-bud of " Fagus sylvatica," Beech-tree.

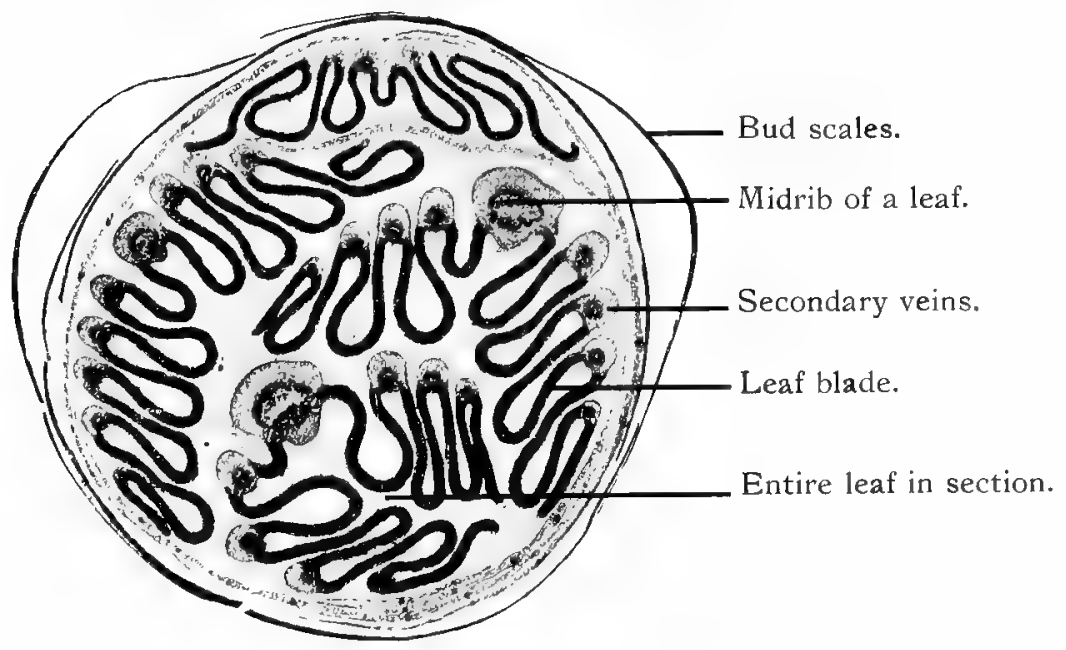

75.--T.S. Leaf-bud of "Fraxinus excelsior."

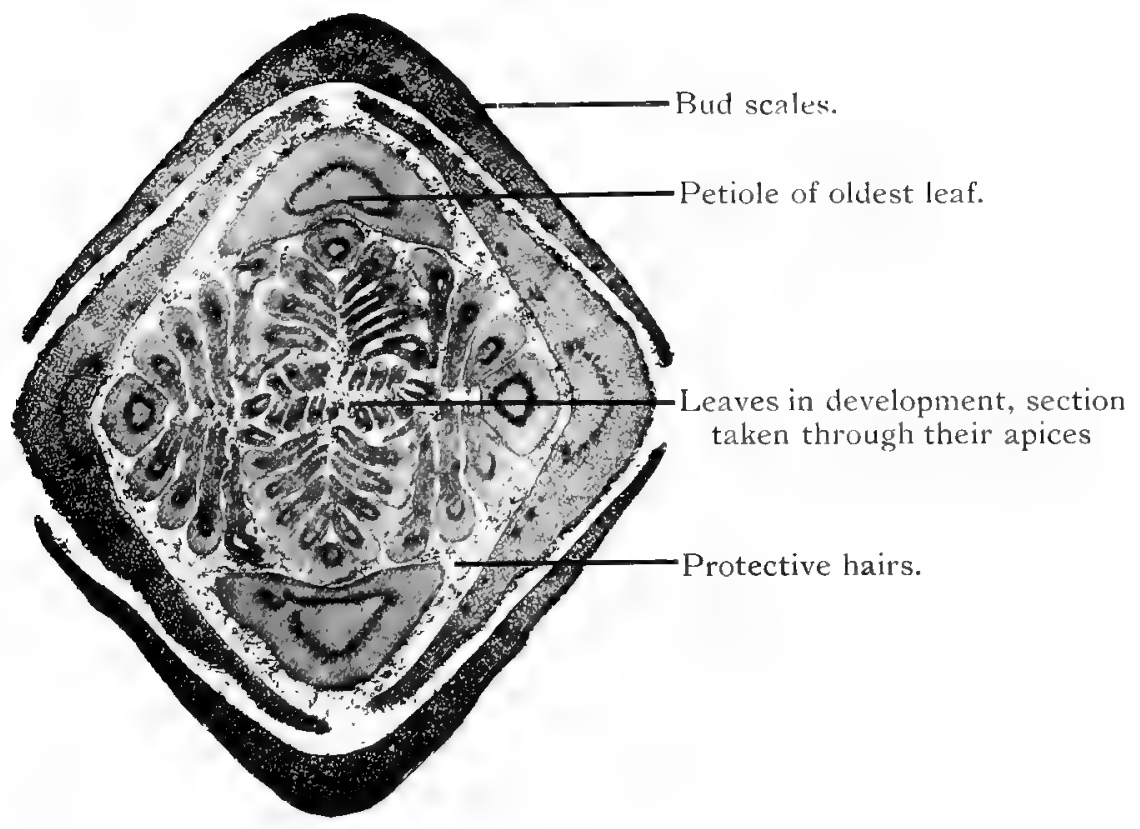


76.-T.S. Leaf-bud of "Acer Pseudo-platanus," Sycamore.

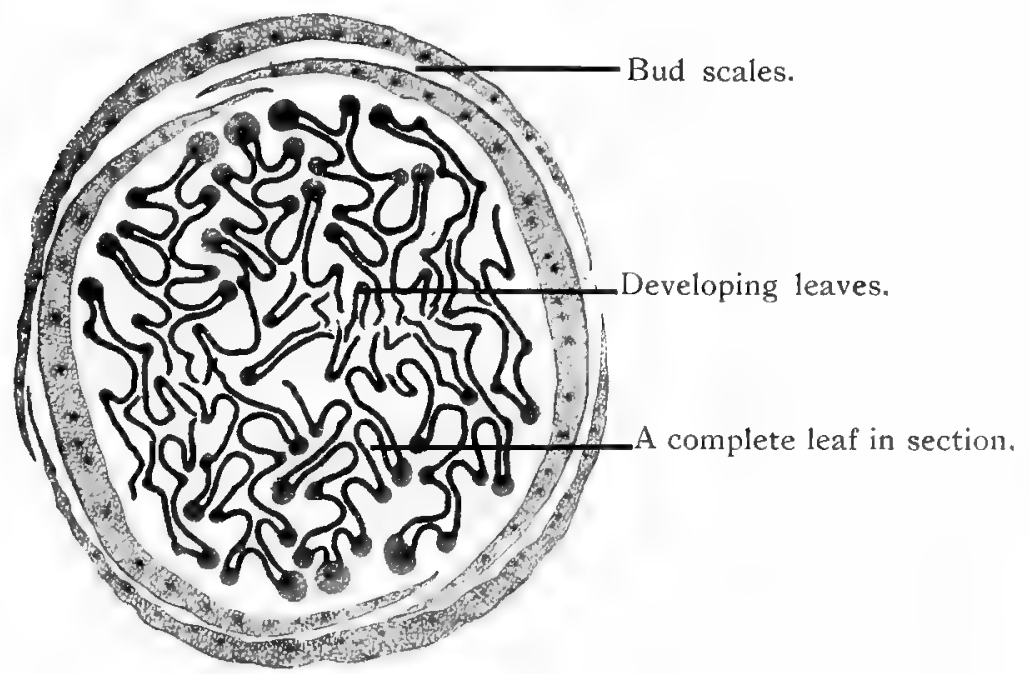

77. - L.S Stem and Leaf-buds of Acer Pseudo-platanus, Sycamore (Defoliation).

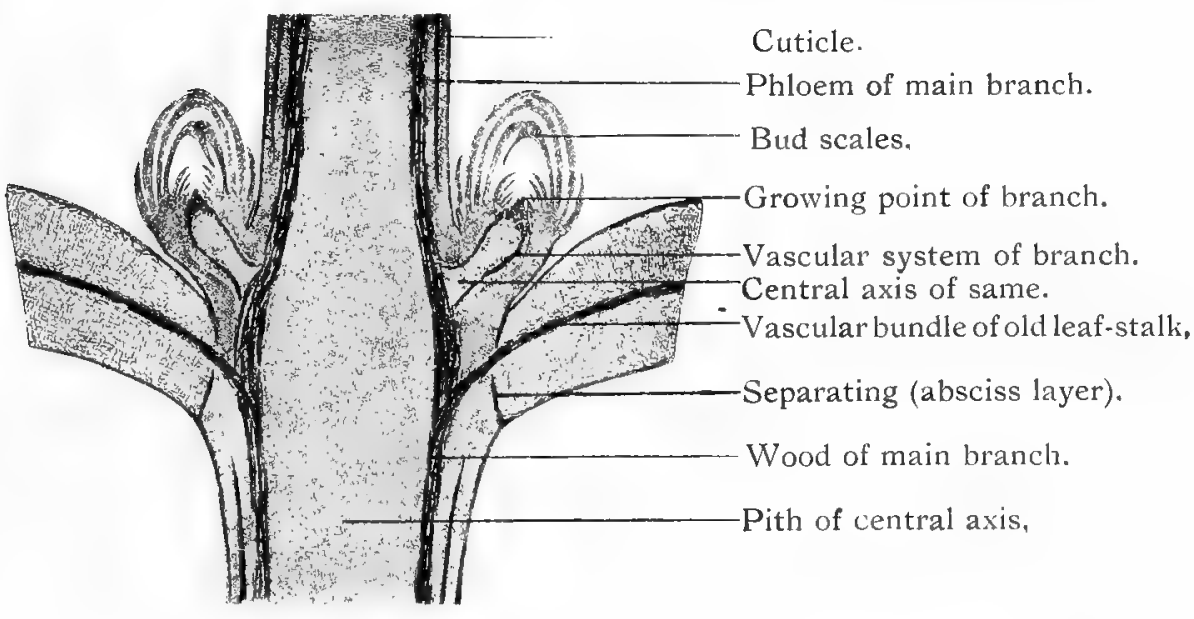


78. -L.S. Flower-bud of “ Gossypium sp.," Cotton plant (Compound Photomicrograph,

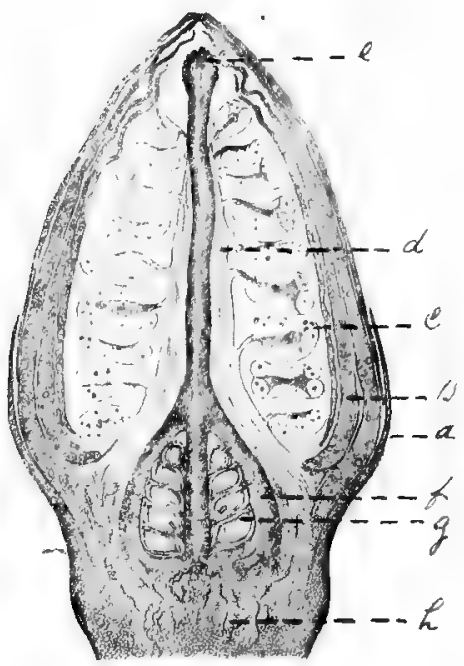

Stigma.

Fleshly pillar to which the anthers are attached.

The anthers containing pollen.

The petals and sepals.

Bract.

Ovary.

Ovules.

Apex of flower-stalk. (Thallamus.)

79.-L.S. Catkin of "Salix caproa," Common sallow.

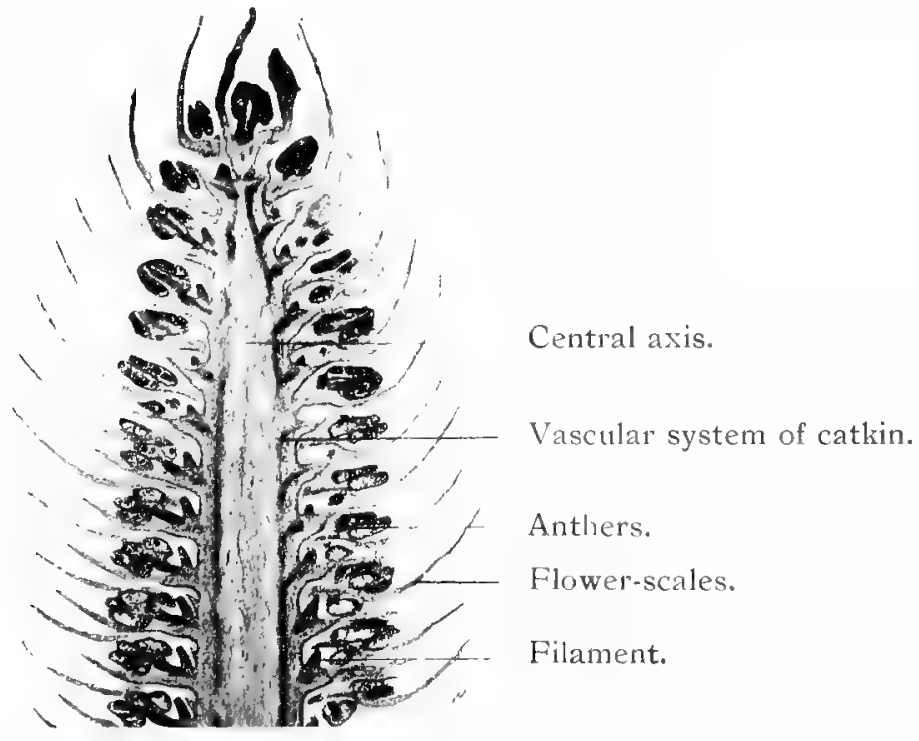


80.-T.S. Flower-bud of "Taraxacum offieinale," Dandelion.

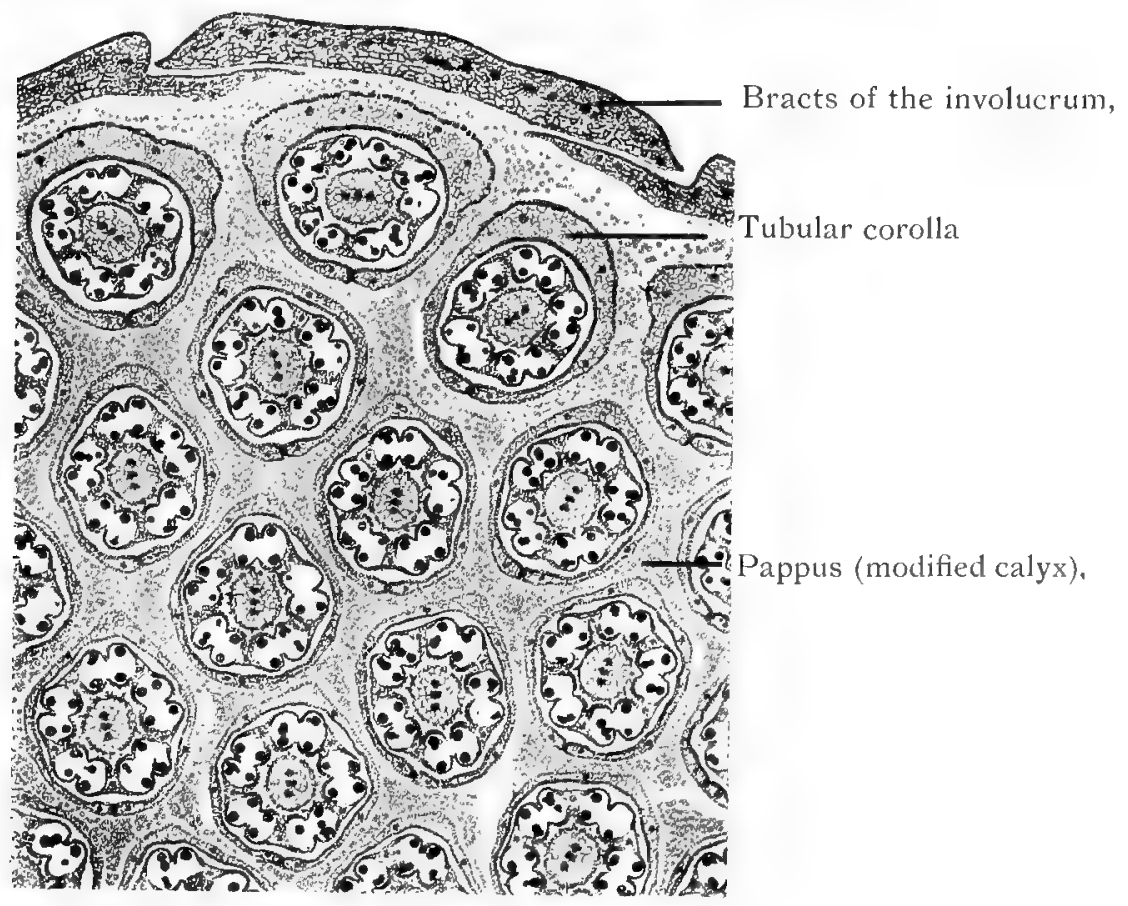

81.-T.S. Flower-bud of "Papaver rhœas," Common Corn poppy.

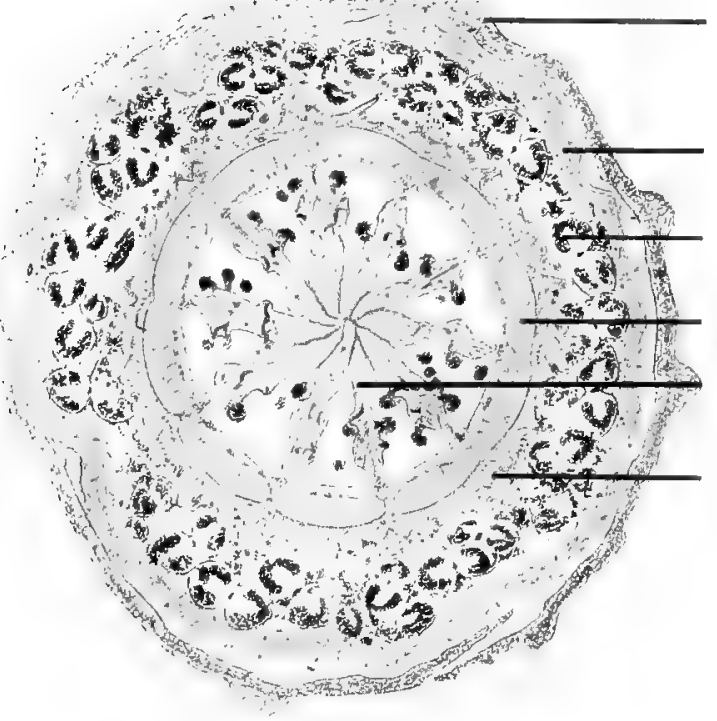

Calyx.

Corolla

Anthers containing pollen.

Wall of ovary

Seed-bearing placenta.

Base of stigmatic cap. 
82. -T.S. Flower-bud, "Cheiranthus cheiri," Wallflower.

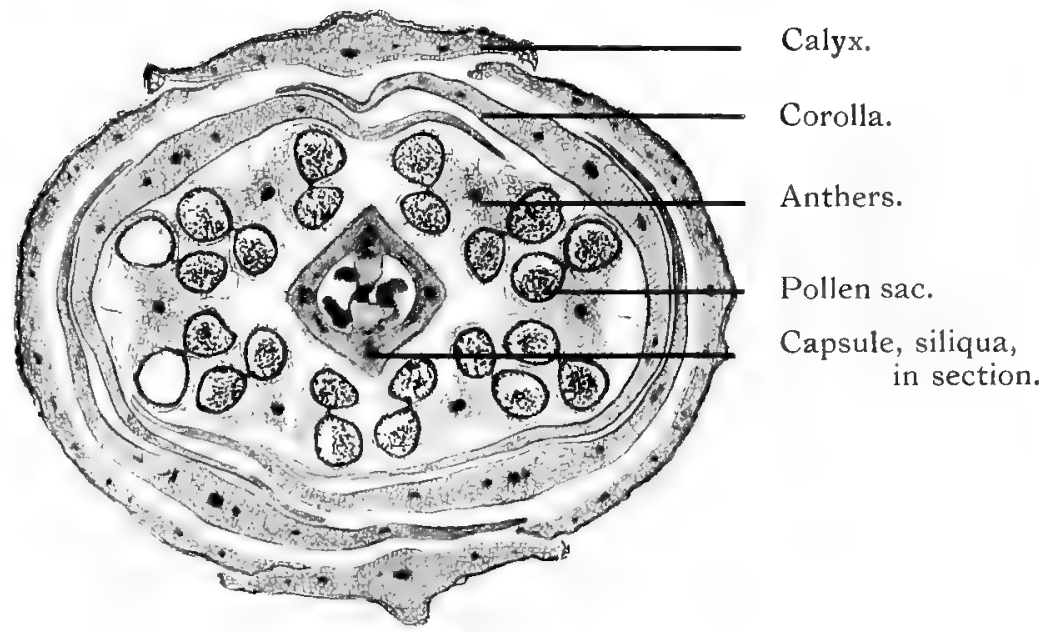

83. - T.S. Flower-bud, "Iris germanica," Purple iris.

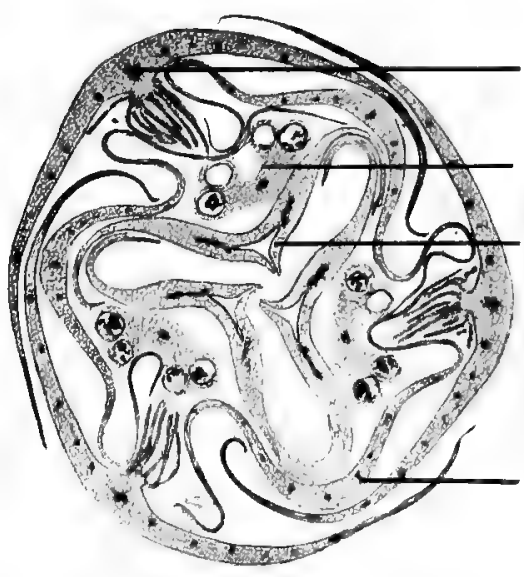

Calyx with fringe of hairs.

Anther.

Petaloid stigmas.

Petals. 
84. - T.S. Flower-bud, "Lilium eroceum," Orange lily.

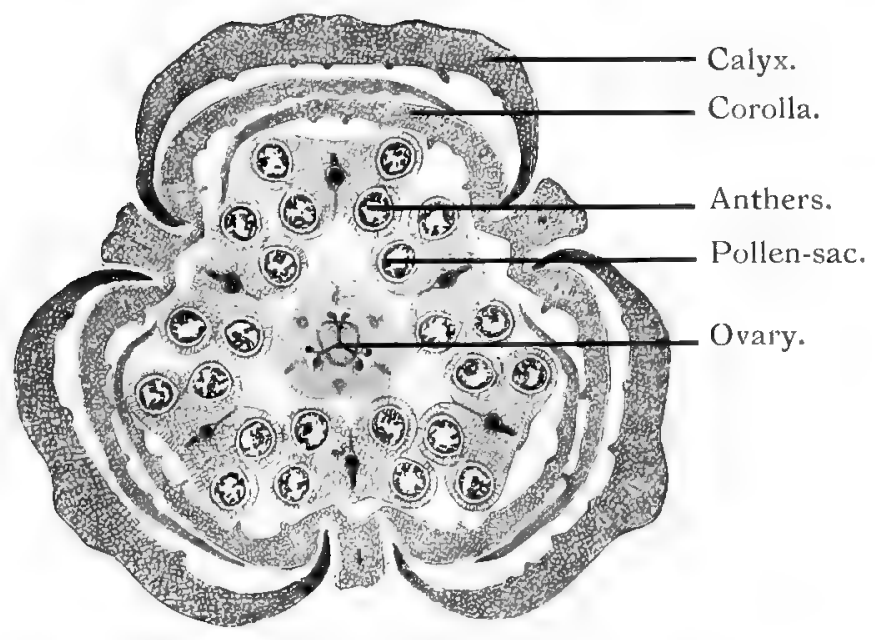

85. - T.S. Anther of "Lilium croceum," Orange lily.

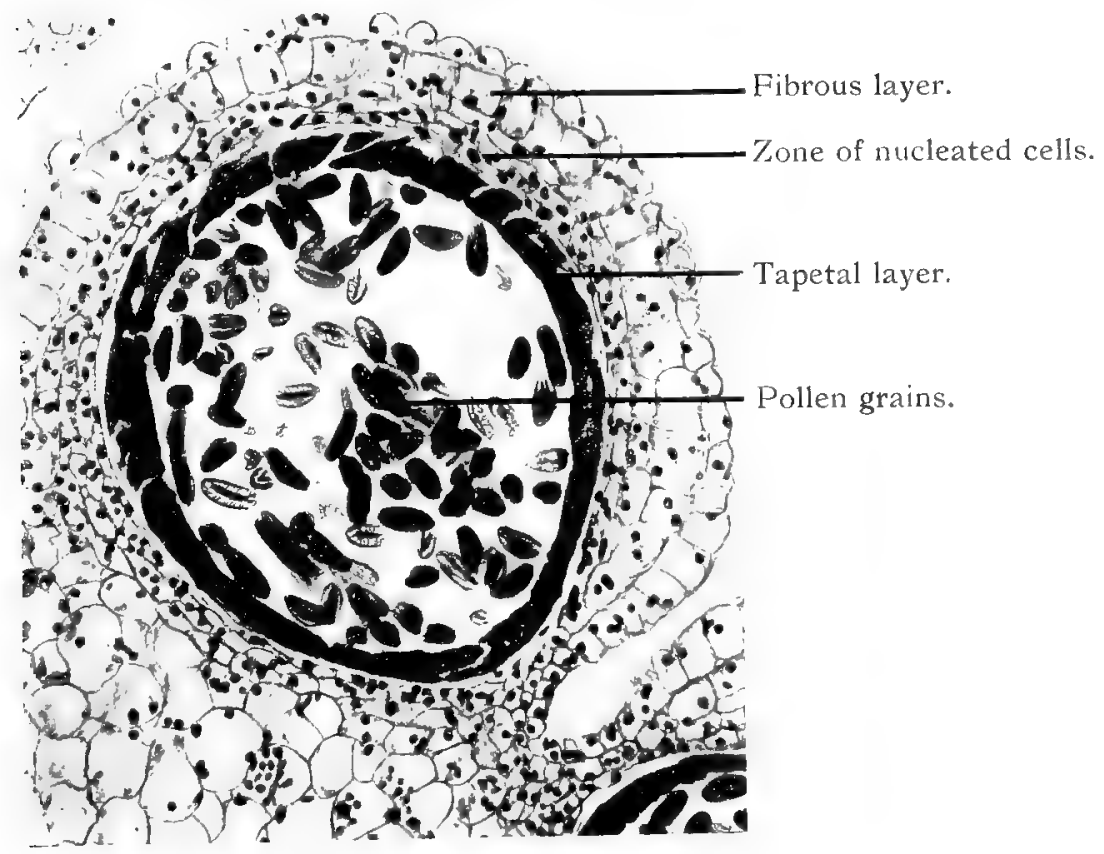


86. -T.S. Ovary of "Lilium croceum," Orange Lily.

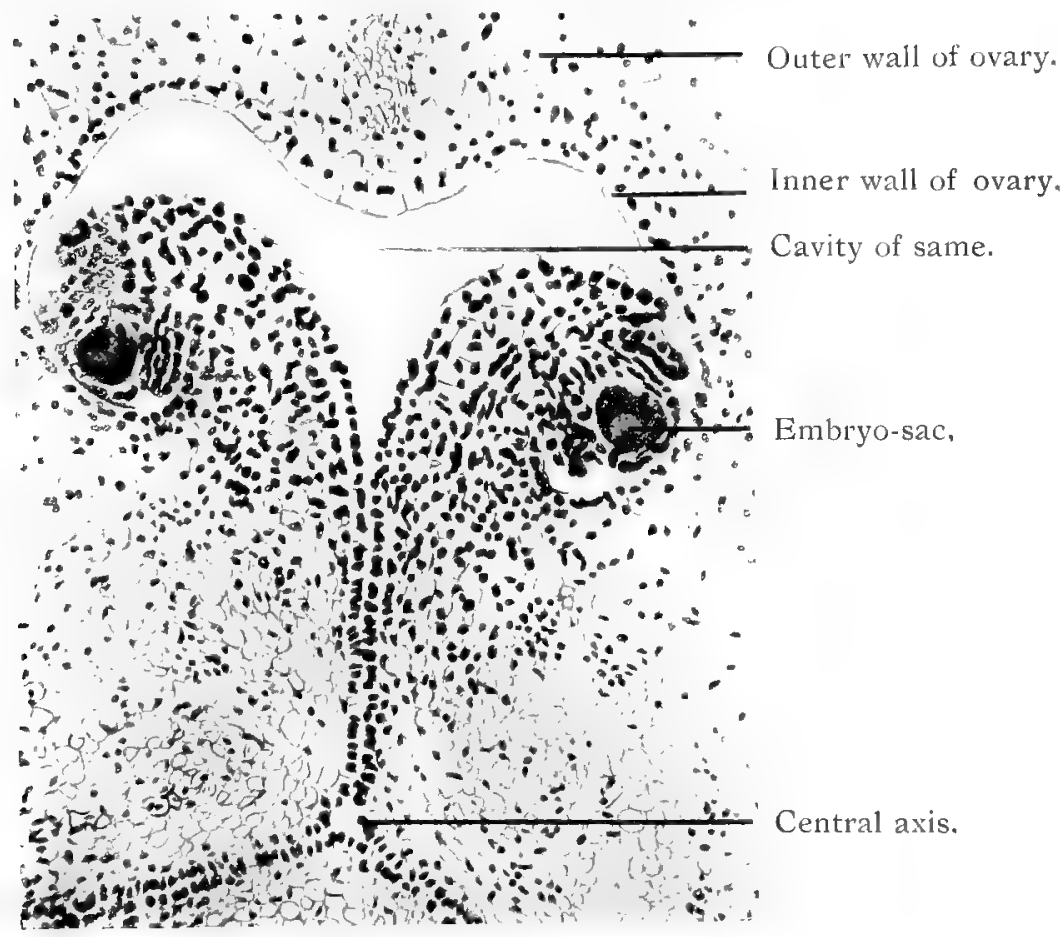

87.-Entire flower of Wheat, "Triticum sativum."
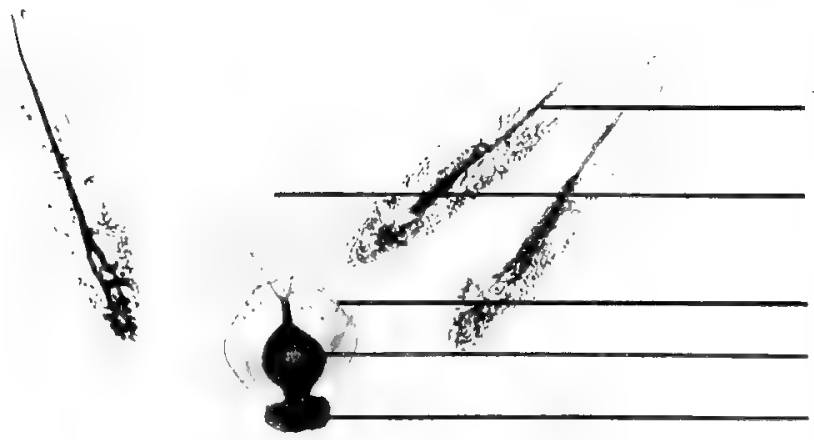

Anthers containing pollen.

Stigma.

Ovary

Embryo-sac. Enlarged base of flower. 


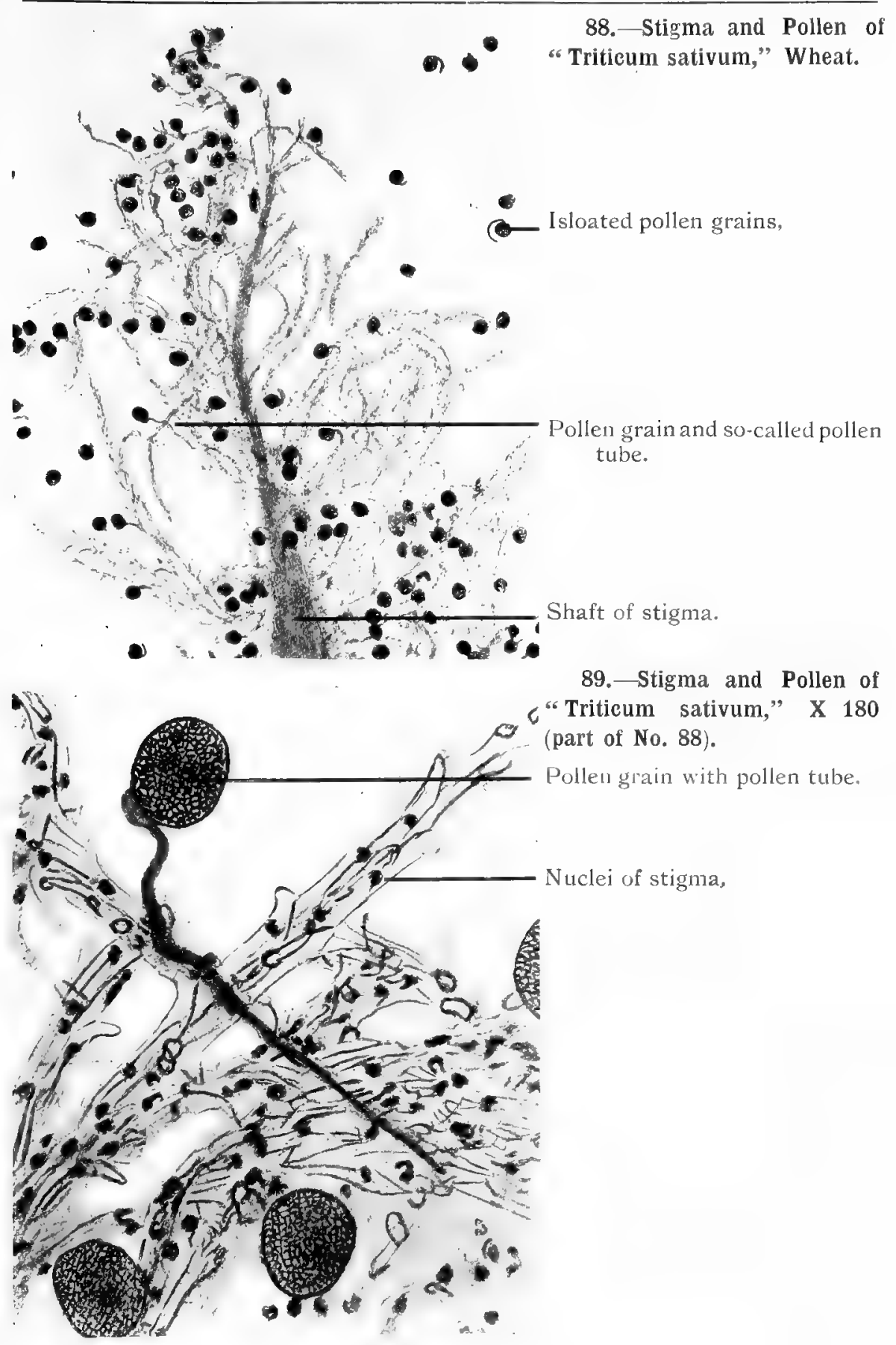


90. -L.S. Embryo-Sac, "Triticum sativum," Wheat.

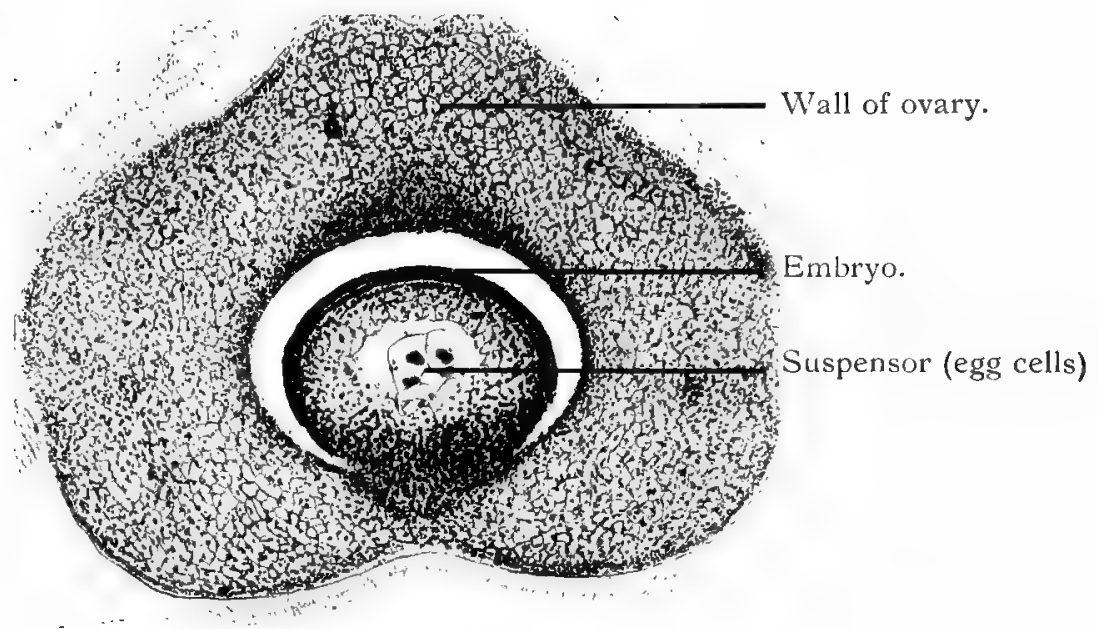

91. L.S. Seed of "Triticum sativum," Wheat.

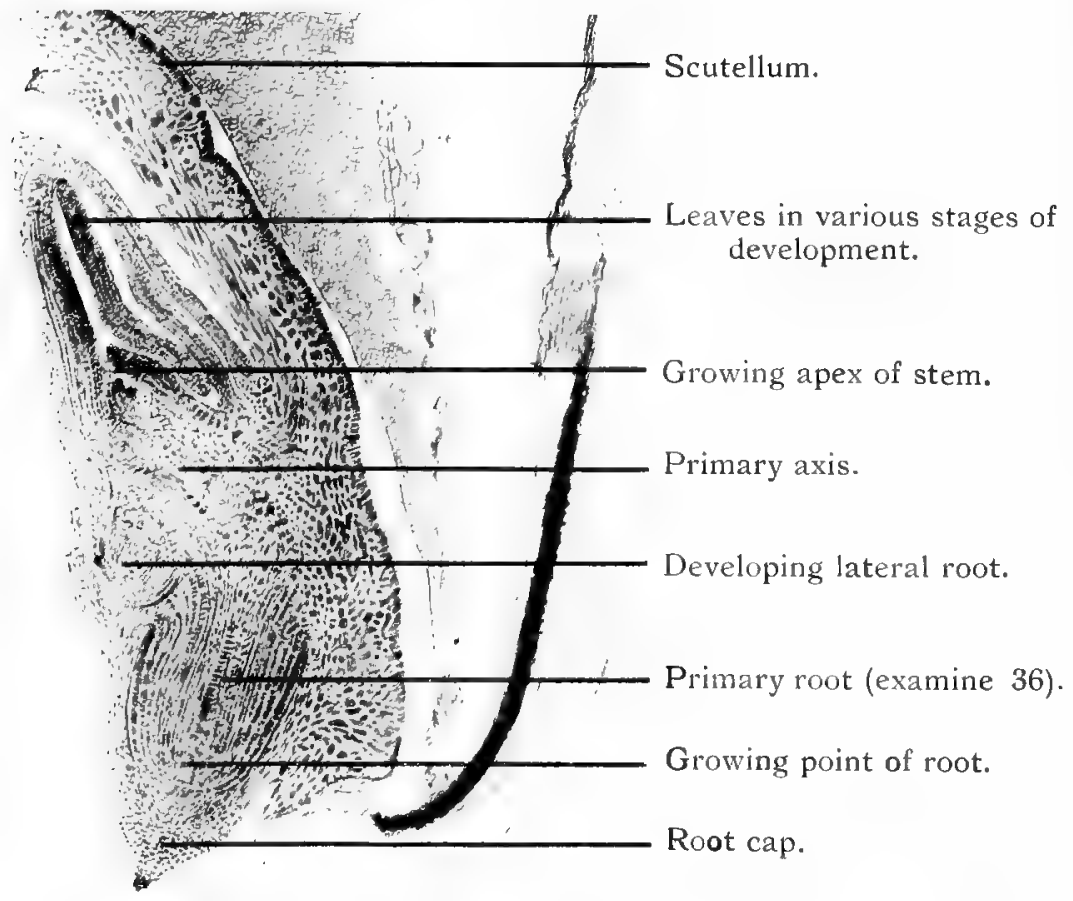


92. - L.S. Plumule of "Triticum sativum," Wheat.

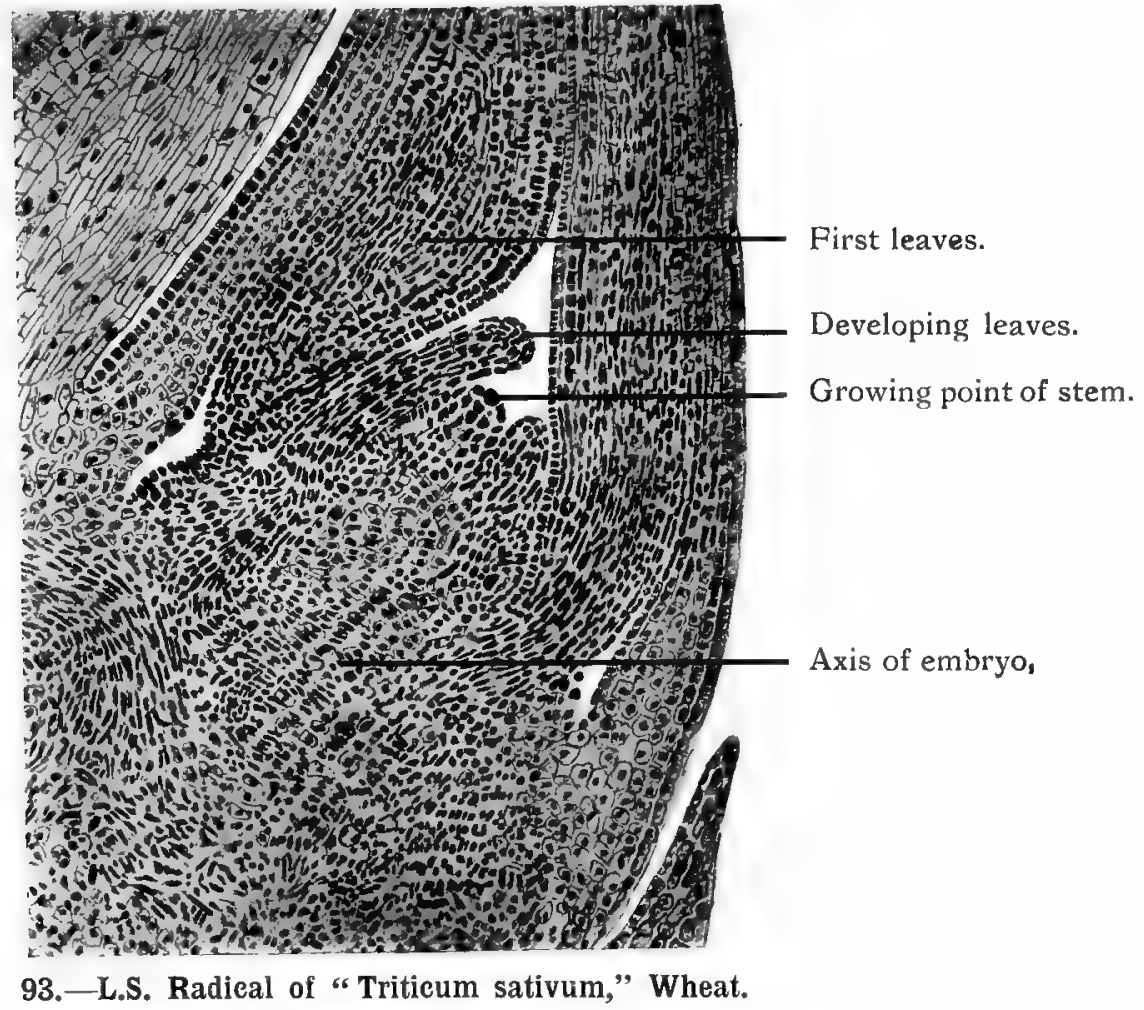

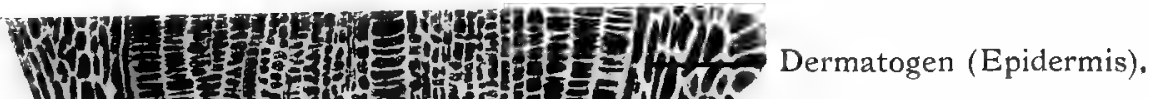

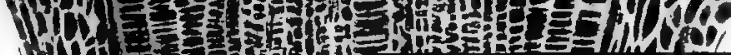

ind 01 entral axis.

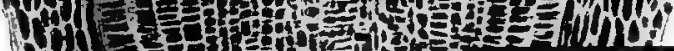

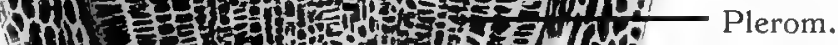

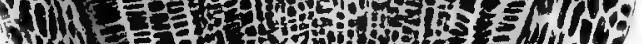

HWh $=20$ -

146 o $=$ a

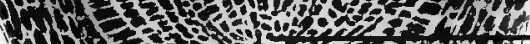

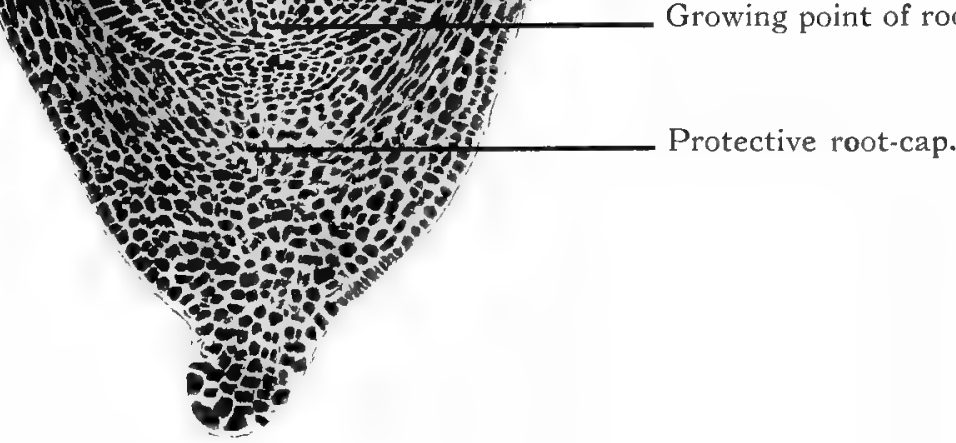


94. - T.S. Seed of "Triticum sativum," portion enlarged.

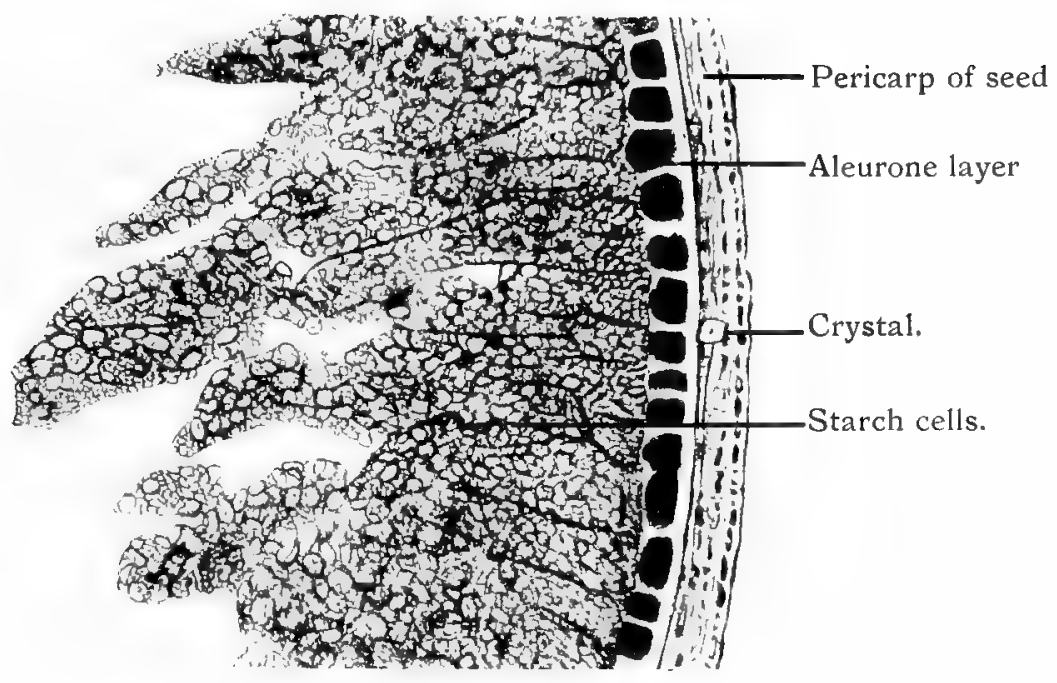

95.-T.S. Cremocarp of "Smyrnium olusatrum," Alexanders.

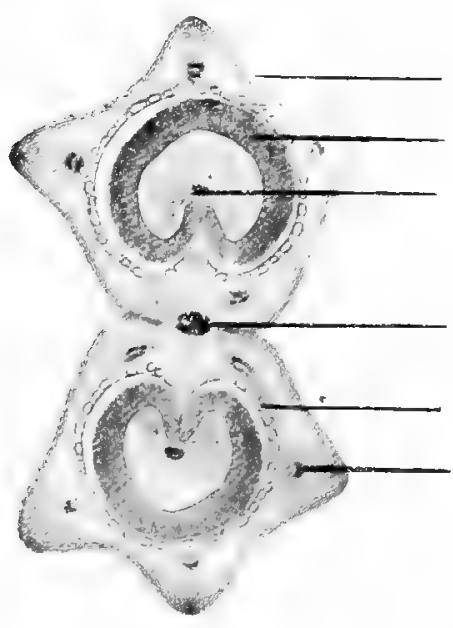

Ridges of mericarp, seed

Endosperm.

Vascular bundle.

Central axis, (connective).

Vittce.

Vascular bundle. 
96. -Entire Capsule of "Capsella bursa-pastoris," Shepherds-purse.

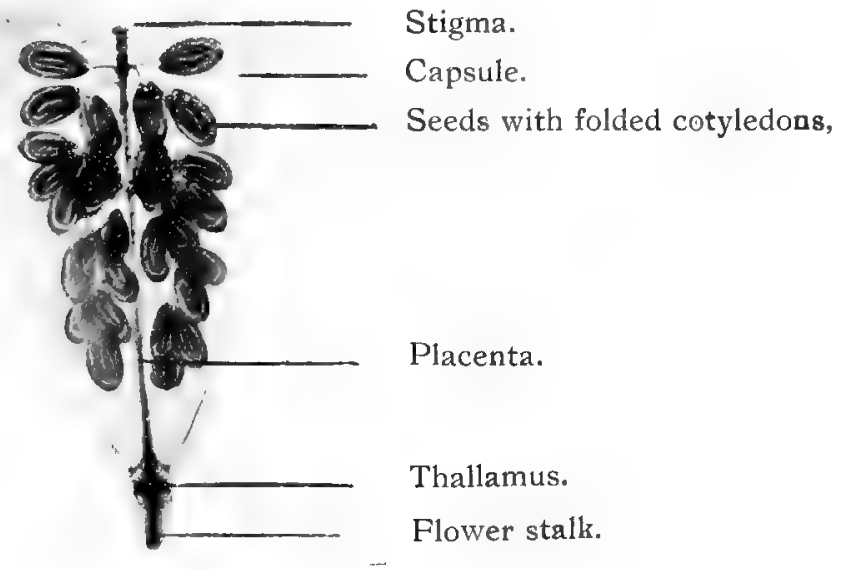

97.--Starch of "Solanum tuberosum," Potato.

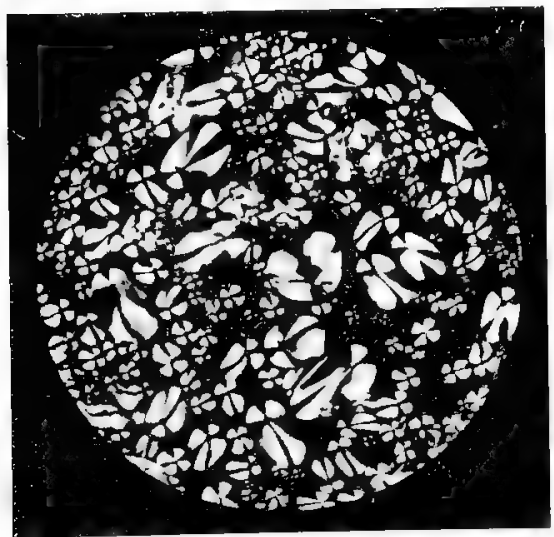

Starch of potato photographed with polarized light. 
98. -T.S. Stem of "Tradiscantia discolor," Tradiscantia.

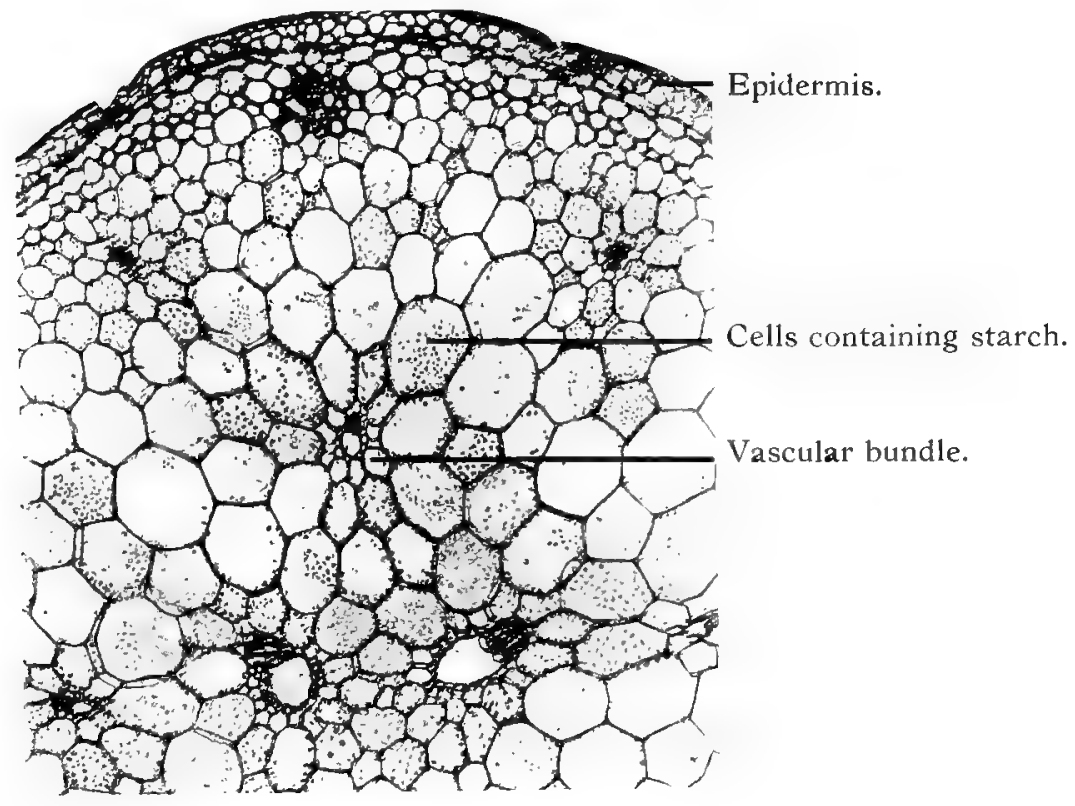

99. -T.S. Seed of "Ricinus communis," Castor Oil plant.

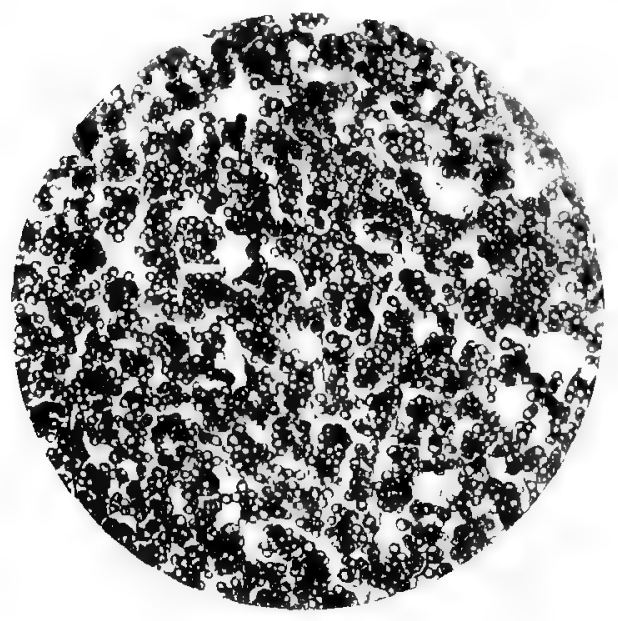

Endosperm cells, containing proten, crystals and aleuronegrains. 
100.-T.S. Corm of "Phajus grandifolius," Orehid.

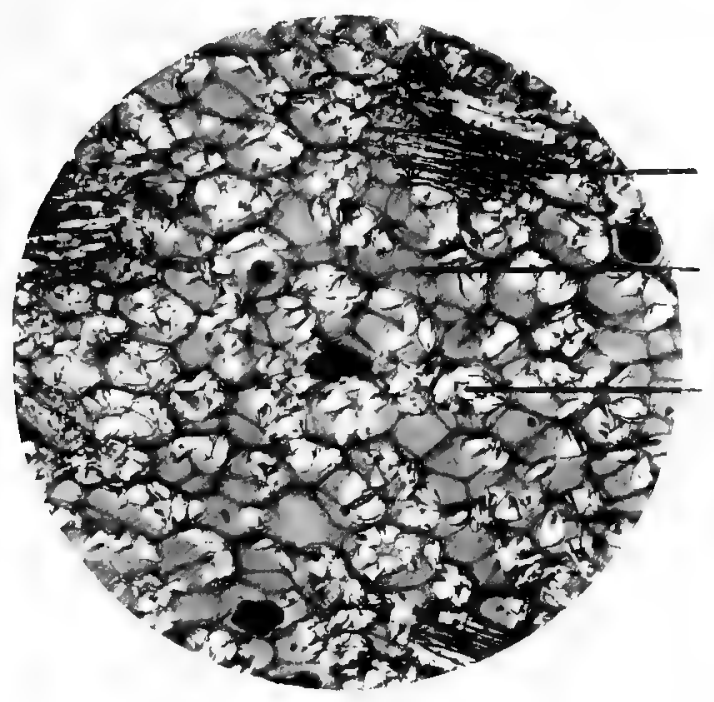

Vascular bundle

Ground tissue.

Starch and lucoplasts.

101.-L.S. Root of "Taraxacum officinale," Dandelion.

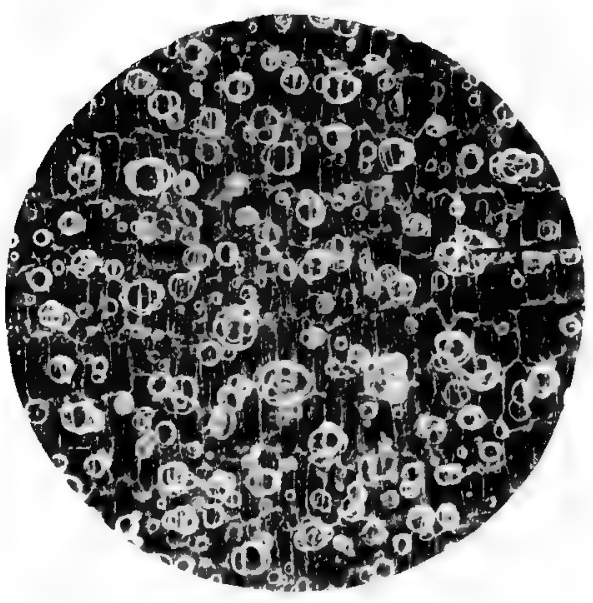

Sphøero-crystals of inuline deposited on cell walls, forming balls of various sizes. 
102.-L.S. Stem of "Euphorbia spliendens," Euphorbia.

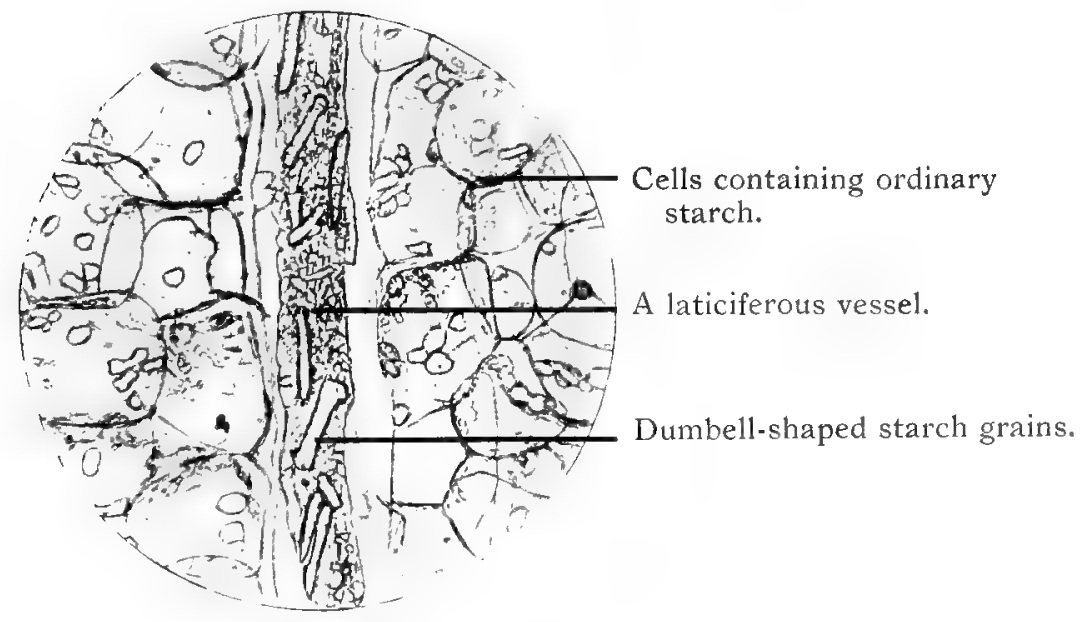

103.-L.S. Root, "Scorzonera hispanica."

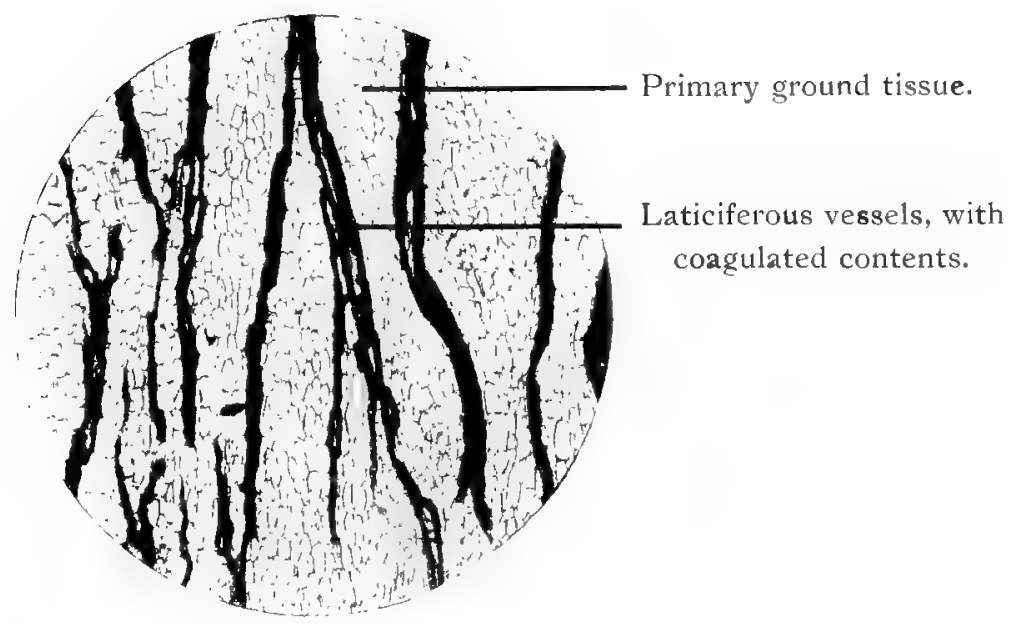



The Artistic Printing Co. (Manchester) Ltd., ALtrincham and London. 
. 




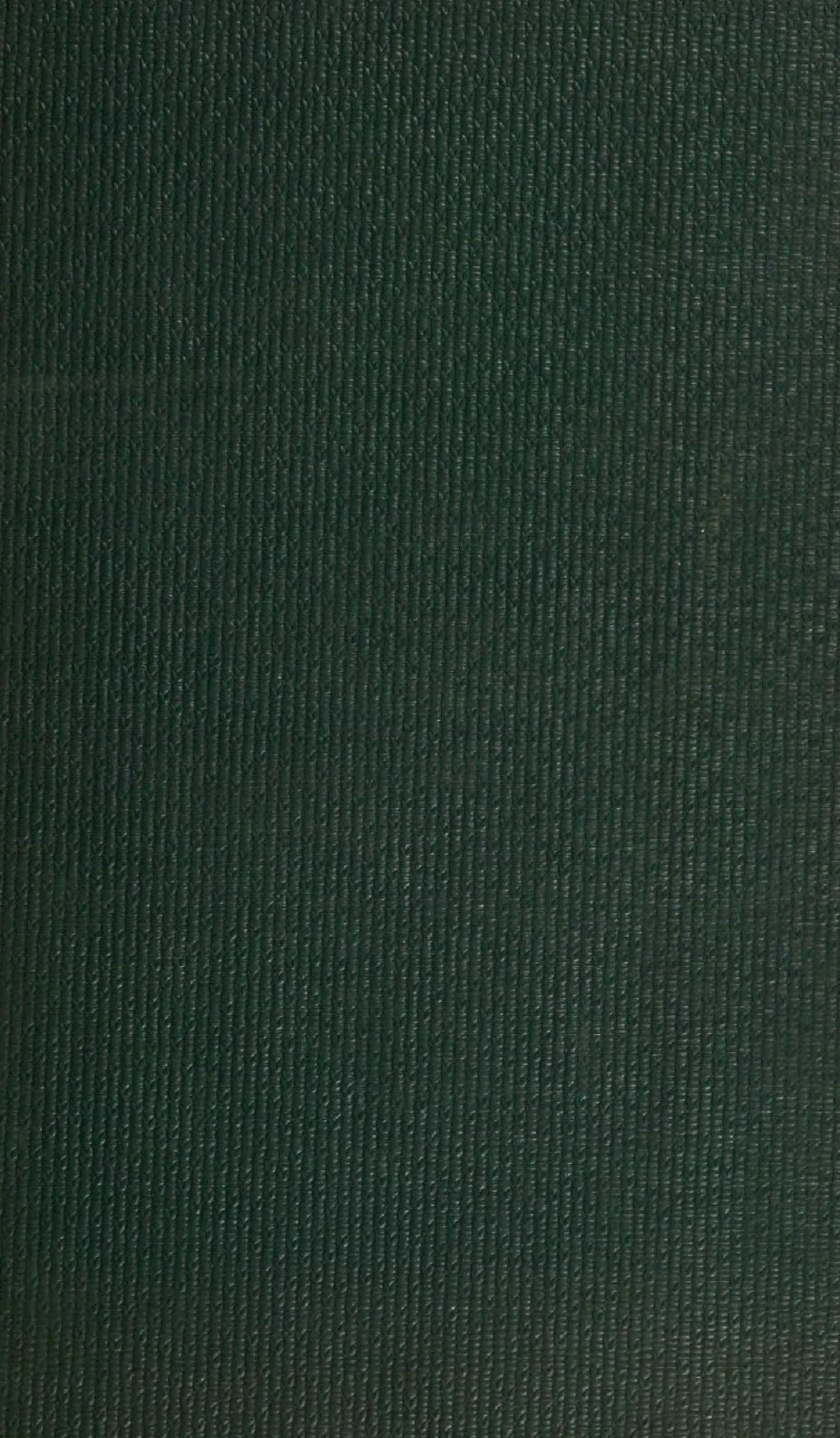

